Supplementary Information for:

\title{
Predicting U.S. residential building energy use and indoor pollutant exposures in the mid-21 ${ }^{\text {st }}$ century
}

Torkan Fazlia ${ }^{\mathrm{a}}$ Xinyi Dong ${ }^{\mathrm{b} 1}$, Joshua S. Fu ${ }^{\mathrm{b}, \mathrm{c}}$, Brent Stephens ${ }^{\mathrm{a}^{*}}$

${ }^{a}$ Department of Civil, Architectural, and Environmental Engineering, Illinois Institute of Technology, Chicago, IL USA

${ }^{\mathrm{b}}$ Department of Civil and Environmental Engineering, University of Tennessee, Knoxville, Knoxville, TN USA

${ }^{\mathrm{c}}$ Computational Earth Sciences Group, Computational Sciences and Engineering Division, Oak Ridge National Laboratory, Oak Ridge, TN USA

* Corresponding author: Brent Stephens, brent@iit.edu

${ }^{1}$ Xinyi Dong is now an Associate Professor in the School of Atmospheric Science, Nanjing University, China (dongxy@nju.edu.cn).

This Supplementary Information (SI) file includes:

Supplementary text

- SI Methods

- SI Results

Figures $\mathrm{S} 1$ to $\mathrm{S} 17$

Tables S1 to S22

SI References

SI Appendices

- Tables A-1 to A-9

Summary:

- Number of pages: 61

- Number of figures: 17

- Number of tables: 31 


\section{SI Methods}

\section{Development of a nationally representative set of combined building energy and indoor air quality (IAQ) models for U.S. residences in the 2010s}

We first developed a set of combined building energy and IAQ models to represent the majority of the U.S. residential building stock in the 2010s. The 2010s model set is an updated version of the REIAQ model set that we previously developed to be representative of $\sim 80 \%$ of the U.S. housing stock as of approximately the late 1990s or early 2000s ${ }^{1}$. The original REIAQ model framework was based on the same home characteristics used in Persily et al. (2006), which developed a collection of multi-zone IAQ models (albeit without energy models) to represent $\sim 80 \%$ of the U.S housing stock based on the 1997 U.S. Energy Information Administration's (EIA's) Residential Energy Consumption Survey (RECS) ${ }^{2}$. In this work, we generated an updated model set for the 2010s using housing characteristics from the 2015 US EIA's RECS database. Data for the 2015 RECS (the latest that is available) were collected between August 2015 and April 2016 and public-use microdata was published online in summer $2018^{3}$. RECS is a collection of detailed statistical information on household energy characteristics for single-family homes, units in multifamily buildings, and mobile homes. The 2015 RECS collected data from more than 5,600 households that were selected to be statistically representative of the 118.2 million housing units occupied as primary residences in the 50 states and the District of Columbia ${ }^{4}$.

\subsection{Sample selection}

We used the same RECS sampling approach as Persily et al. (2006) to develop a collection of housing units to represent $\sim 80 \%$ of the U.S. housing stock in the 2010s (with 2015 serving as the representative housing stock year). Sample selection was conducted for each of the four building types in RECS individually, including detached single-family homes, attached single-family homes, manufactured homes, and apartments. Several defining variables are used in RECS to characterize each building type, each with a number of sub-variables (Table S1). For example, Foundation type is a variable with three sub-variables consisting of 'finished basement,' 'unfinished basement,' and 'no basement.' A factorial design was used to define all possible combinations of variables and then select the most prevalent units that represent at least $80 \%$ of the housing stock of each building type. In the factorial design, variables are labeled as "factors," each with discrete possible sub-variables, labeled as "levels," to define all possible combinations of these levels across all factors. The variables and sub-variables used are the same as those used in Persily et al. (2006) ${ }^{2}$, with a few exceptions.

The resulting number of possible combinations for each building type as defined in Table $\mathrm{S} 1$ is as follows: 540 attached and detached single-family homes (i.e., combination of 6 factors with 2, 3, 5, 2, 3, and 3 levels); 40 apartments (i.e., combination of 4 factors with 2, 2, 5, and 2 levels); and 20 manufactured homes (i.e., combination of 3 factors with 2, 5, and 2 levels). The goal of our sampling approach was to reduce the number of unique homes such that we could manually construct a minimal amount of home models that still represent at least $80 \%$ of the U.S. housing stock. To do so, each of the 5,600+ homes in the 2015 RECS database was given a categorical numeric score for each factor (i.e., variable) based on their characteristics of each sub-variable (i.e., level) as defined in Table S1 (e.g., "1" for no forced air and " 2 " for forced air; "1" for year built $<1950$ and " 5 " for year built 2010-2015). The combinations of these scores were then used to generate a characteristic ID for each home in the RECS database based on the ranges of levels defined in Table S1 (e.g., "224132" describes a 2-story single-family home with attached garage, no basement, built between 1990-2009, forced air heating/cooling, and a floor area of 149-223 $\mathrm{m}^{2}$ ). Each unique characteristic ID represents a unique home; duplicate characteristic IDs represent homes that, while they are actually different in the RECS database, have sufficient overlap in fundamental characteristics that they can be used to reasonably represent the same baseline home in the simplified model set. Each home in the RECS database also has a weight assigned to it that defines how many homes it represents nationwide. These weighting values for each RECS housing unit were then matched by characteristic ID to define a 
single housing unit that represents multiple homes in the database with identical combinations of levels resulting from the factorial analysis, and then weighting values were summed across homes with identical characteristic IDs. For each building type, the resulting characteristic IDs were then sorted in descending order based on their summed total weight.

\begin{tabular}{|c|c|c|c|}
\hline $\begin{array}{l}\text { Variables } \\
\text { (Factors) }\end{array}$ & $\begin{array}{l}\text { Sub-variables } \\
\text { (Levels) }\end{array}$ & $\begin{array}{l}\text { Variables } \\
\text { (Factors) }\end{array}$ & $\begin{array}{l}\text { Sub-variables } \\
\text { (Levels) }\end{array}$ \\
\hline \multicolumn{2}{|c|}{$\begin{array}{c}\text { Single Family } \\
\text { (attached and detached) }\end{array}$} & \multicolumn{2}{|c|}{ Apartments } \\
\hline \multirow{2}{*}{ Forced air } & No & \multirow{2}{*}{ \# of units } & $2-4$ \\
\hline & Yes & & $\geq 5$ \\
\hline \multirow{3}{*}{ Floor Area $\left(\mathbf{m}^{2}\right)$} & $<149$ & \multirow{2}{*}{ Forced air } & No \\
\hline & $149-223$ & & Yes \\
\hline & $>223$ & \multirow{2}{*}{$\begin{array}{l}\text { Floor Area } \\
\left(\mathrm{m}^{2}\right)\end{array}$} & $<93$ \\
\hline \multirow{5}{*}{ Year built } & $<1950$ & & $\geq 93$ \\
\hline & 1950-1969 & \multirow{5}{*}{ Year built } & $<1950$ \\
\hline & $1970-1989$ & & $1950-1969$ \\
\hline & $1990-2009$ & & 1970-1989 \\
\hline & $2010-2015$ & & 1990-2009 \\
\hline \multirow{2}{*}{ Garage } & Yes & & $2010-2015$ \\
\hline & No & \multicolumn{2}{|c|}{ Manufactured homes } \\
\hline \multirow{3}{*}{ Foundation } & $\begin{array}{l}\text { Finished } \\
\text { Basement }\end{array}$ & \multirow{2}{*}{ Forced air } & No \\
\hline & $\begin{array}{l}\text { Unfinished } \\
\text { Basement }\end{array}$ & & Yes \\
\hline & No Basement & \multirow{2}{*}{$\begin{array}{l}\text { Floor Area } \\
\left(\mathrm{m}^{2}\right)\end{array}$} & $<149$ \\
\hline \multirow{3}{*}{ \# of stories } & 1 & & $\geq 149$ \\
\hline & 2 & \multirow{5}{*}{ Year built } & $<1950$ \\
\hline & $\geq 3$ & & 1950-1969 \\
\hline & & & 1970-1989 \\
\hline & & & 1990-2009 \\
\hline & & & $2010-2015$ \\
\hline
\end{tabular}

Figure S1 shows the percentage of unique combinations of characteristic IDs for each of the four building types that were included to obtain a representative sample size, which, similar to Persily et al. (2006) ${ }^{2}$, we defined as at least $80 \%$ of the U.S. housing stock. Table S2 shows the total number of housing unit combinations that were selected that represent $\sim 80 \%$ of the U.S. housing stock within each of the four building types as of 2015, as well as the fraction of homes that each sample represents. For Apartments and Manufactured homes, 23 and 6 individual homes were needed to represent the $80 \%$ of the housing stock type, respectively. However, none of the selected homes were built after 2010. Therefore, for each of these building types, one additional home is added to be able to account for apartments and manufactured homes built after 2010. The result is a set of 217 unique housing units defined using the most prevalent combinations of characteristics in Table 1, which combined represent approximately $81.3 \%$ of the U.S. housing stock in 2015. Approximately 50\% of these defined units are detached homes, $36 \%$ are attached homes, $11 \%$ are apartments, and $3 \%$ are mobile homes. 


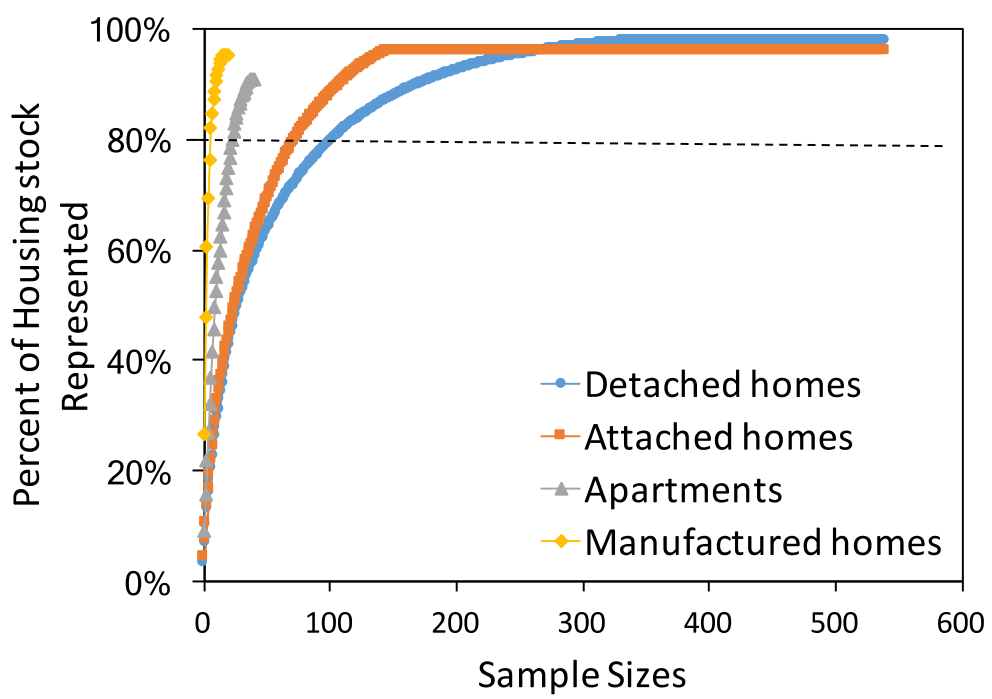

Figure S1. Sample size vs. percentage of housing units in the 2015 RECS database analysis

Table S2. Number of selected housing units and percentages of housing units represented in the 2015 RECS database analysis

\begin{tabular}{|c|c|c|}
\hline House type & $\begin{array}{c}\text { Sample } \\
\text { size }\end{array}$ & \% Represented \\
\hline Detached (DH) & 107 & $80.7 \%$ \\
\hline Attached (AH) & 79 & $82.0 \%$ \\
\hline Apartments (APT) & 24 & $81.0 \%$ \\
\hline Mobile Homes (MH) & 7 & $83.2 \%$ \\
\hline Total & 217 & $81.0 \%$ \\
\hline
\end{tabular}

\subsection{Developing baseline floor plans}

After identifying the basic home characteristics to represent $>80 \%$ of the housing stock in 2015 , we identified key variables needed to develop baseline floor plans in BEopt for energy and airflow modeling, including the home type, number of floors, basement type, garage existence, heated floor area, number of bedrooms, number of bathrooms, and forced air system existence. In BEopt, all detached homes and manufactured homes were modeled as free-standing structures without any adjacent units; attached homes and apartment units are modeled assuming an existence of adjacent units in the form of two sidewalls. All manufactured homes and apartments are modeled as one-story homes. Detached and attached single-family homes are modeled as one-, two-, or three-story homes depending on their characterization in the 2015 RECS data. Any homes with more than three stories are modeled as three-story homes for simplicity. Manufactured homes and apartment units were modeled with no attached garage; however, some attached and detached homes have attached garages in RECS database. Attached garages were modeled for these two home types as having a floor area of $49.1 \mathrm{~m}^{2}$ for homes $<223 \mathrm{~m}^{2}$ and $53.5 \mathrm{~m}^{2}$ for homes $>223 \mathrm{~m}^{2}$ (following procedures in Persily et al. 2006) ${ }^{2}$. Because all attached homes are modeled as homes with two side walls connected to adjacent homes already, their attached garages are modeled as connected to the lowest story above to the basement, if it exists. All attached garages are modeled as adjacent unconditioned spaces. To calculate the heated floor area of each of the 217 baseline homes within the different home types, we used the same floor area categories derived in Persily et al. (2006) (Table S3). The floor areas assigned to each category are calculated as the dwelling weighted average of all RECS homes for each home type and floor area category such that each home model is generally representative of the average size home in each category. 
Table S3. Estimated floor areas for different home types and various floor area categories

\begin{tabular}{|c|c|c|}
\hline \multirow{2}{*}{ Home Type } & $\begin{array}{c}\text { Floor area category, } \\
\mathbf{m}^{\mathbf{2}}\left(\mathbf{f t}^{\mathbf{2}} \mathbf{)}\right.\end{array}$ & $\begin{array}{c}\text { Floor area in model, } \\
\mathbf{m}^{\mathbf{2}} \mathbf{( f t}^{\mathbf{2}} \mathbf{)}\end{array}$ \\
\hline \multirow{4}{*}{ Detached } & $<149(1599)$ & $110.4(1188.4)$ \\
\cline { 2 - 3 } & $149-223(1600-2399)$ & $181.9(1958)$ \\
\cline { 2 - 3 } & $>223(2400)$ & $320.8(3453.2)$ \\
\hline \multirow{3}{*}{ Attached } & $<149(1599)$ & $106.7(1148.8)$ \\
\cline { 2 - 3 } & $149-223(1600-2399)$ & $180.5(1942.6)$ \\
\cline { 2 - 3 } Apartments & $>223(2400)$ & $275.2(2962.5)$ \\
\cline { 2 - 3 } & $<93(1000)$ & $68.3(735.4)$ \\
\hline \multirow{3}{*}{ Manufactured } & $>93(1000)$ & $117.7(1267.2)$ \\
\cline { 2 - 3 } & $>149(1599)$ & $98.6(1061.7)$ \\
\hline
\end{tabular}

Single-family homes in the U.S. are commonly built with one of three foundation types: basement, slab, or crawlspace. The 2015 RECS dataset only provides data on whether the housing unit is built over a basement or not, and also if a basement (if it exists) is a finished (i.e., conditioned) or unfinished (i.e., unconditioned) space. Therefore, we also used the previous 2009 RECS dataset ${ }^{5}$, which provided more specific data on different foundation types, to assign an appropriate type of foundation for each representative home model in BEopt based on geographic location. We also used data from the Census Bureau, Characteristics of New Housing ${ }^{6}$, to make assumptions for single family homes without basement foundations. The type of foundation for each home model was selected based on the most prevalent foundation type in either the U.S. census division (for 2006 RECS data) or the U.S. census region (for the Census Bureau data), along with the year of construction assigned to each baseline home. Table S4 summarizes the foundation data derived from these two sources. All manufactured homes are modeled with crawlspaces and all apartment buildings are modeled with concrete slabs. All attics and garages are also considered unconditioned spaces. 
Table S4. Foundation type for homes without basements for different construction years and locations based on Census Bureau and REC 2009 data

\begin{tabular}{|c|c|c|c|c|c|c|c|c|}
\hline \multirow{3}{*}{$\begin{array}{c}\begin{array}{c}\text { U.S. } \\
\text { Census } \\
\text { Division }\end{array} \\
\begin{array}{c}\text { South } \\
\text { Atlantic }\end{array}\end{array}$} & \multirow{3}{*}{$\begin{array}{c}\begin{array}{c}\text { U.S. } \\
\text { Census } \\
\text { Region }\end{array} \\
\text { South }\end{array}$} & \multirow{2}{*}{$\begin{array}{c}\text { RECS } \\
\mathbf{2 0 0 9} \\
>1950\end{array}$} & \multirow{2}{*}{$\begin{array}{c}\begin{array}{c}\text { RECS } \\
\mathbf{2 0 0 9}\end{array} \\
1950-1969\end{array}$} & $\begin{array}{l}\text { Census } \\
\text { Bureau }\end{array}$ & $\begin{array}{c}\text { RECS } \\
2009 \\
\end{array}$ & $\begin{array}{l}\text { Census } \\
\text { Bureau }\end{array}$ & $\begin{array}{c}\text { RECS } \\
2009 \\
\end{array}$ & \multirow{2}{*}{\begin{tabular}{|c|}
$\begin{array}{c}\text { Census } \\
\text { Bureau }\end{array}$ \\
$2010-2015$
\end{tabular}} \\
\hline & & & & \multicolumn{2}{|c|}{ 1970-1989 } & \multicolumn{2}{|c|}{ 1990-2009 } & \\
\hline & & Crawlspace & Slab & Slab & Slab & Slab & Slab & Slab \\
\hline $\begin{array}{c}\text { West } \\
\text { South } \\
\text { Central }\end{array}$ & South & Crawlspace & Slab & Slab & Slab & Slab & Slab & Slab \\
\hline Mountain & West & Crawlspace & Slab & Slab & Slab & Slab & Slab & Slab \\
\hline $\begin{array}{c}\text { East South } \\
\text { Central }\end{array}$ & South & Crawlspace & $\begin{array}{l}\text { Crawl } \\
\text { space }\end{array}$ & Slab & Slab & Slab & Slab & Slab \\
\hline $\begin{array}{c}\text { West } \\
\text { South } \\
\text { Central }\end{array}$ & South & Crawlspace & Slab & Slab & Slab & Slab & Slab & Slab \\
\hline $\begin{array}{c}\text { South } \\
\text { Atlantic }\end{array}$ & South & Crawlspace & Slab & Slab & Slab & Slab & Slab & Slab \\
\hline Pacific & West & Crawlspace & Slab & Slab & Slab & Slab & Slab & Slab \\
\hline $\begin{array}{c}\text { Middle } \\
\text { Atlantic }\end{array}$ & Northeast & Crawlspace & Slab & Slab & Slab & Slab & Slab & Slab \\
\hline $\begin{array}{c}\text { West } \\
\text { North } \\
\text { Central }\end{array}$ & Midwest & Crawlspace & Slab & $\begin{array}{l}\text { Crawl } \\
\text { space }\end{array}$ & Slab & Slab & Slab & Slab \\
\hline $\begin{array}{c}\text { South } \\
\text { Atlantic }\end{array}$ & South & Crawlspace & Slab & Slab & Slab & Slab & Slab & Slab \\
\hline $\begin{array}{c}\text { New } \\
\text { England }\end{array}$ & Northeast & Crawlspace & Slab & Slab & Slab & Slab & Slab & Slab \\
\hline $\begin{array}{l}\text { East South } \\
\text { Central }\end{array}$ & South & Crawlspace & $\begin{array}{l}\text { Crawl } \\
\text { space }\end{array}$ & Slab & Slab & Slab & Slab & Slab \\
\hline $\begin{array}{c}\text { East North } \\
\text { Central }\end{array}$ & Midwest & Crawlspace & Slab & $\begin{array}{l}\text { Crawl } \\
\text { space }\end{array}$ & $\begin{array}{l}\text { Crawl } \\
\text { space }\end{array}$ & Slab & Slab & Slab \\
\hline Pacific & West & Crawlspace & Slab & Slab & Slab & Slab & Slab & Slab \\
\hline $\begin{array}{l}\text { East North } \\
\text { Central }\end{array}$ & Midwest & Crawlspace & Slab & $\begin{array}{l}\text { Crawl } \\
\text { space }\end{array}$ & $\begin{array}{l}\text { Crawl } \\
\text { space }\end{array}$ & Slab & Slab & Slab \\
\hline $\begin{array}{c}\text { Middle } \\
\text { Atlantic }\end{array}$ & Northeast & Crawlspace & Slab & Slab & Slab & Slab & Slab & Slab \\
\hline $\begin{array}{c}\text { New } \\
\text { England }\end{array}$ & Northeast & Crawlspace & Slab & Slab & Slab & Slab & Slab & Slab \\
\hline Mountain & West & Crawlspace & $\begin{array}{l}\text { Crawl } \\
\text { space }\end{array}$ & Slab & Slab & Slab & $\begin{array}{l}\text { Crawl } \\
\text { space }\end{array}$ & Slab \\
\hline $\begin{array}{c}\text { West } \\
\text { North } \\
\text { Central }\end{array}$ & Midwest & Crawlspace & Slab & $\begin{array}{l}\text { Crawl } \\
\text { space }\end{array}$ & Slab & Slab & Slab & Slab \\
\hline
\end{tabular}

Another variable that was needed to develop the 217 baseline floor plans in BEopt is the number of bedrooms and bathrooms in each housing unit. The 2015 RECS dataset provides information about the number of bedrooms, other rooms, bathrooms, and half bathrooms. For each of the 217 home models, the percentage of the housing units with each number of the mentioned room types was calculated. A weighted average of the number of each room type reported for each of the 217 baseline homes was then calculated and rounded to the nearest whole number to use in each representative home model floor plan in BEopt. Similar to the method was used in Fazli and Stephens (2018) ${ }^{1}$, we first manually built 217 base model 
geometries in BEopt and run the models to generate 217 XML input files. BEopt XML files provide a complete description of a single building with an element for every input found in the BEopt interface ${ }^{7}$. Later, using an automated scripting process these 217 base model home geometries were edited to incorporate other important home characteristics that were assumed to vary by climate zone and year of construction, with each of the 19 cities having a different proportion of homes assigned by vintage, types of heating and cooling system, building envelope insulation levels, and thermostat settings.

The primary characteristics of each residence from the baseline collection (i.e., floor area, year built, number of floors, foundation type, whether or not they have a forced air distribution system, and the presence or lack of an attached garage) with assigned weighting value are shown in the Appendix of this SI (Tables A-1 through A-4).

\subsection{Location of dwellings}

Next, the collection of 217 model homes was used to assign baseline home model geometries across 19 of the most populous U.S. cities that also cover all ASHRAE climate zones and all 9 U.S. census divisions. These same 19 cities were used in both Fazli and Stephens (2018) ${ }^{1}$ and Persily et al. (2010) ${ }^{8}$. At this point, 2012 was selected as the representative year for the 2010s model set primarily because we had previously obtained hourly ambient air quality data ${ }^{9}$ and actual year meteorological data ${ }^{10}$ for each of these 19 locations in 2012. Thus, while the model set was developed to represent the housing stock as of 2015 using 2015 RECS data, the remaining inputs, including weather, air quality, and population movement factors, are chosen to represent the year 2012. We expect only minor discrepancies in using these two different marker years to represent the housing stock as of the $\sim 2010$ s because only a small fraction of the overall housing stock was constructed between 2012 and 2015. According to the 2012 U.S. Census, the total U.S. population was 313,993,272, distributed among the 9 U.S. Census Division as shown in Table S5.

Table S5. U.S. population distribution among nine Census Divisions in $2012{ }^{11}$
\begin{tabular}{|c|c|}
\hline Census Divisions & $\begin{array}{c}\text { Population in } \\
\mathbf{2 0 1 2}\end{array}$ \\
\hline New England & $14,584,723$ \\
\hline Middle Atlantic & $41,275,538$ \\
\hline East North Central & $46,568,813$ \\
\hline West North Central & $20,749,482$ \\
\hline South Atlantic & $61,215,000$ \\
\hline East South Central & $18,631,214$ \\
\hline Mountain & $22,595,566$ \\
\hline Pacific & $50,927,422$ \\
\hline Total & $313,993,272$ \\
\hline
\end{tabular}

We used the same estimates of the relative proportion of dwellings in each of the 9 Census Divisions, as well as the allocation of dwellings among the 2 or 3 selected metropolitan areas that represent each U.S. census division, as Persily et al. (2010) ${ }^{8}$. The total number of dwellings that were modeled in this study using the 2015 RECS dataset was 118,205,582 homes. These homes are distributed between the 19 representative cities using the dwelling-weighted values for each representative 217 baseline homes from the 2015 RECS dataset and also the division covered percentages the same used for population distribution. Table S6 shows the distribution of both population and dwellings among the 19 representative cities. The proportion of each time of individual home model across each of the 9 U.S. Census Divisions are shown in the Appendix of this SI (Tables A-6 through A-9). The assignment of these baseline home models among the 19 representative cities results in a total of 4,123 home models in the form of BEopt XML files (i.e., 217 homes $\times 19$ cities $=4123$ home models). 
Table S6. Population and dwelling number for 19 cities

\begin{tabular}{|l|l|l|}
\hline Cities & $\begin{array}{l}\text { U.S. } \\
\text { Population } \\
\mathbf{2 0 1 2}\end{array}$ & \# of Dwellings \\
\hline Atlanta, GA & $17,568,705$ & $6,693,420$ \\
\hline Birmingham, AL & $5,589,364$ & $2,272,808$ \\
\hline Boston, MA & $11,609,440$ & $3,758,845$ \\
\hline Buffalo, NY & $9,163,169$ & $3,232,384$ \\
\hline Chicago, IL & $40,561,436$ & $16,459,013$ \\
\hline Cincinnati, OH & $6,007,377$ & $2,437,672$ \\
\hline Corpus Christi, TX & $7,489,103$ & $3,062,002$ \\
\hline Dallas/Fort Worth, TX & $29,956,411$ & $12,248,008$ \\
\hline Denver, CO & $11,953,054$ & $4,851,485$ \\
\hline Los Angeles, CA & $36,209,397$ & $11,311,605$ \\
\hline Miami, FL & $18,609,360$ & $7,089,894$ \\
\hline Minneapolis, MN & $8,569,536$ & $3,608,754$ \\
\hline Nashville, TN & $13,041,850$ & $5,303,219$ \\
\hline New York, NY & $32,112,369$ & $11,327,905$ \\
\hline Phoenix, AZ & $10,642,512$ & $4,319,564$ \\
\hline Seattle, WA & $14,718,025$ & $4,597,825$ \\
\hline St. Louis, MO & $12,179,946$ & $5,129,149$ \\
\hline Washington, DC & $25,036,935$ & $9,538,706$ \\
\hline Worcester, MA & $2,975,283$ & 963,322 \\
\hline Total & $313,993,272$ & $118,205,582$ \\
\hline & & \\
\hline
\end{tabular}

\subsection{Detailed building characteristics in the 2010s model set}

Next, detailed home characteristics were assigned to each of the resulting 4,123 home models based primarily on location, vintage, and floor area.

\subsubsection{Building envelope airtightness}

Assumptions for the airtightness of the building envelope as a function of year of construction, building floor area, and geographic location were derived from the Lawrence Berkeley National Laboratory's Residential Diagnostics Database (ResDB) ${ }^{12}$, which contains air leakage data from over 147,000 U.S. homes, including single-family detached and attached homes, multi-family homes, and manufactured homes. Figure S2 shows the average Normalized Leakage (NL) values from ResDB for homes with different floor areas, year of construction, and geographic location. The NL data demonstrate that, as expected, newer (and larger) homes tend to have tighter exterior building envelopes compared to older (and smaller) homes, which ultimately influences air infiltration through the envelope. Figure S2 also demonstrates that envelope airtightness also varies with climate zone. Next, because BEopt estimates air infiltration through the building envelope using air changes per hour at an indoor-outdoor pressure difference of $50 \mathrm{~Pa}$ (i.e., $\mathrm{ACH}_{50}$ ) to define the envelope airtightness, NL values from Figure S2 were converted to $\mathrm{ACH}_{50}$ using typical pressure and flow relationships from fan pressurization tests that was previously used in Fazli and Stephens (2018) ${ }^{1}$, as shown in Equations S1-4 ${ }^{13}$ and Table S7. 


$$
\begin{aligned}
& Q=E L A \sqrt{\frac{2 P_{r}}{\rho}}\left(\frac{\Delta P}{P_{r}}\right)^{n} \\
& N L=1000 \frac{E L A}{A_{f}}\left(\frac{H}{2.5 m}\right)^{0.3} \\
& A C H_{50}=\frac{Q_{50}}{V} \\
& A C H_{50}=N L \times \frac{66}{H^{1.3}}
\end{aligned}
$$

Where $Q=$ airflow rate $\left(\frac{m^{3}}{s}\right), E L A=$ effective leakage area $\left(m^{2}\right), P_{r}=$ reference pressure $(P a), \rho=$ air density $\left(\frac{\mathrm{kg}}{\mathrm{m}^{3}}\right), \Delta P=$ indoor-outdoor pressure difference $(P a), n=$ pressure exponent $(-), A_{f}=$ floor area $\left(\mathrm{m}^{2}\right), H=$ height $(m), Q_{50}=$ airflow rate at a pressure difference of $50 \mathrm{~Pa}\left(\mathrm{~m}^{3} / \mathrm{h}\right)$, and $V=$ volume of the building $\left(\mathrm{m}^{3}\right)$. We assumed $n=\frac{2}{3}$ and $\rho=1.2 \frac{\mathrm{kg}}{\mathrm{m}^{3}}$ for typical conditions to estimate $\mathrm{ACH}_{50}$ directly from NL using Equation S4.

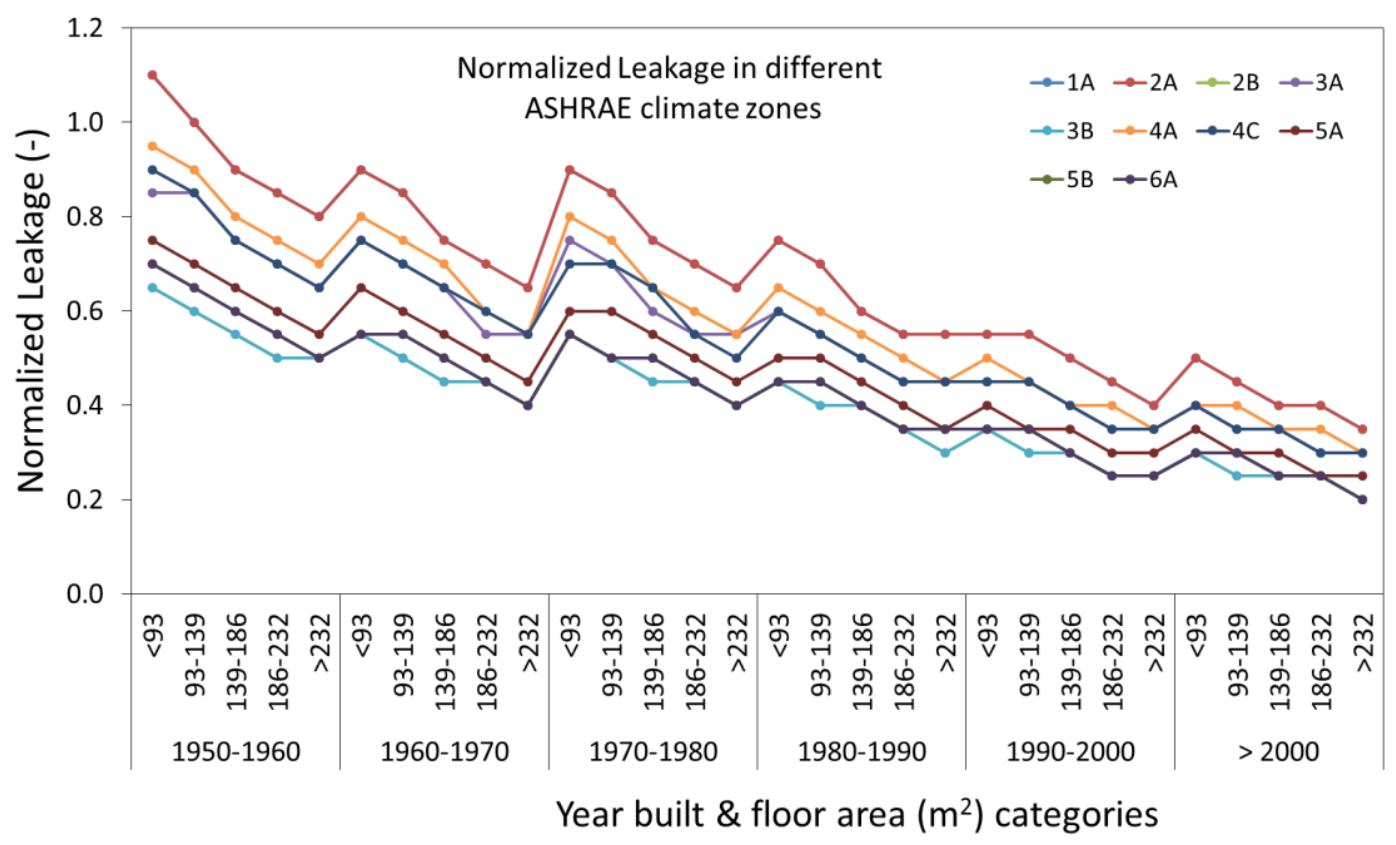

Figure S2. Normalized Leakage (NL) as a function of year built and floor area for different ASHRAE climate zones from ResDB ${ }^{12}$ 
Table S7. Estimates of exterior building enclosure airtightness $\left(\mathrm{ACH}_{50}\right)$ based on vintage, floor area, and climate zone

\begin{tabular}{|c|c|c|c|c|c|c|c|c|c|c|}
\hline \multirow{3}{*}{ Year built } & \multicolumn{10}{|c|}{ ASHRAE Climate Zones } \\
\hline & $1 \mathrm{~A}$ & $2 \mathrm{~A}$ & $2 \mathrm{~B}$ & $3 \mathrm{~A}$ & $3 B$ & $4 \mathrm{~A}$ & $4 \mathrm{C}$ & $5 \mathrm{~A}$ & $5 B$ & $6 \mathrm{~A}$ \\
\hline & \multicolumn{10}{|c|}{$\mathrm{ACH}_{50}(1 / \mathrm{h})$ - Floor Area $>147 \mathrm{~m}^{2}$} \\
\hline$<1950$ & 19 & 19 & 12 & 16 & 12 & 17 & 16 & 14 & 13 & 13 \\
\hline 1950-1970 & 16 & 16 & 10 & 13 & 10 & 14 & 13 & 11 & 10 & 10 \\
\hline 1970-1990 & 13 & 13 & 8 & 11 & 8 & 11 & 11 & 9 & 8 & 8 \\
\hline $1990-2010$ & 9 & 9 & 5 & 7 & 5 & 7 & 7 & 6 & 5 & 5 \\
\hline \multirow[t]{2}{*}{$2010-2020$} & 6 & 6 & 4 & 5 & 4 & 5 & 5 & 4 & 3 & 3 \\
\hline & \multicolumn{10}{|c|}{$\mathrm{ACH}_{50}(1 / \mathrm{h})-$ Floor Area $<147 \mathrm{~m}^{2}$} \\
\hline$<1950$ & 24 & 24 & 14 & 20 & 14 & 21 & 20 & 17 & 15 & 15 \\
\hline 1950-1970 & 20 & 20 & 12 & 16 & 12 & 18 & 17 & 14 & 13 & 13 \\
\hline 1970-1990 & 17 & 17 & 10 & 13 & 10 & 15 & 13 & 11 & 10 & 10 \\
\hline $1990-2010$ & 11 & 11 & 6 & 9 & 6 & 9 & 9 & 7 & 7 & 7 \\
\hline $2010-2020$ & 7 & 7 & 4 & 6 & 4 & 6 & 6 & 5 & 5 & 5 \\
\hline
\end{tabular}

\subsubsection{Building envelope and duct system thermal performance}

The building envelope and duct system thermal performance of each housing unit was assigned based on both vintage and location (shown in the Appendix of this SI; Table A-5). Building envelope thermal performance characteristics, including insulation levels for walls, roofs, and floors and U-values and solar heat gain coefficients (SHGC) for windows, as well as insulation levels for duct systems located outside of conditioned space, for homes built before 1990 were assigned using prior surveys of typical U.S. building construction data for years of construction between 1940 and $1990^{14,15}$ (same as in ${ }^{1}$ ).

For the newer home models representing those built between 1990 and 2009, building envelope and duct system thermal performance characteristics were assigned using requirements from the 2000 International Energy Conservation Code (IECC) ${ }^{16}$, assuming that new homes built to the 2000 IECC reasonably represent the average of homes built between 1990 and 2009. For the newest home models representing those built after 2010 (i.e., 2010-2015), assumptions for building envelope and duct system thermal performance characteristics in each location were assigned based on data of state-level adoption of building codes from the Building Codes Assistance Program ${ }^{17}$. We used minimum requirements for building envelope thermal performance for each location based on the adopted energy codes for year 2012 for each state, as shown in Figure S3 (taken directly from the BCAP database). 


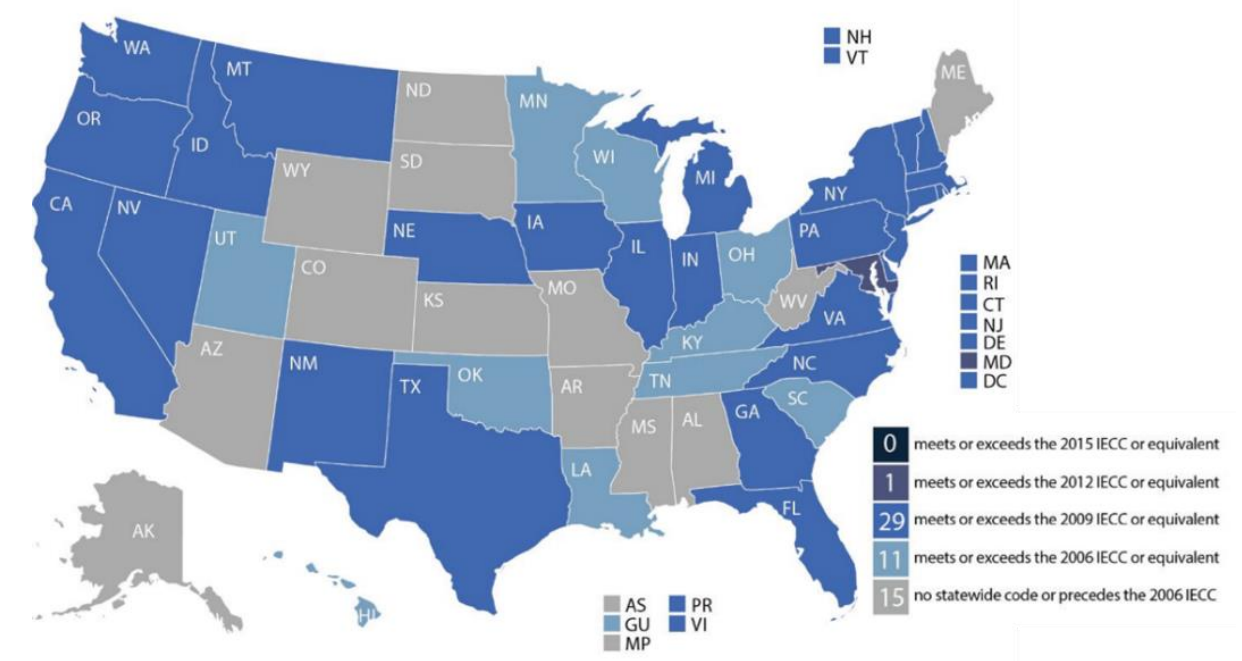

Figure S3. Statewide adoption of residential energy codes in effect in year 2012. Image source: ${ }^{17}$

\subsubsection{Heating and cooling systems}

Each of the 217 baseline home models was first categorized as having one of two primary types of heating and/or cooling systems - either with or without central forced-air distribution systems - based on the most common type listed in the 2015 RECS dataset. Subsets of these two types of heating and/or cooling systems were further defined for each of the 4,123 home models using the 2015 RECS dataset as well. In RECS, central heating systems are listed as either gas, electric, or oil furnace, or air-source heat pump systems. Homes without central heating systems were listed as being equipped with either a gas or oil boiler, or with electric baseboard heat. For cooling systems, central forced-air air-conditioning was assumed for homes with central forced-air heating systems, except for heat pump systems, which provide both heating and cooling in an integrated system, and for homes with room air conditioners (i.e., no central air-conditioner). We assumed that all central forced-air distribution systems were located in unconditioned spaces with $10 \%$ duct leakage to the exterior for simplicity (same as in ${ }^{1}$ ). No whole-house mechanical ventilation systems are modeled in this study, although they have been increasing in popularity in recent years.

From there, the nominal efficiency of heating and cooling equipment in each home was assumed based on the year of construction. Two main sources were used to estimate the heating and cooling equipment efficiencies for different years of construction. The first is Home energy Saver (HES), which is developed by Lawrence Berkeley National Laboratory (LBNL) and provides comprehensive documentation to use for calculating energy use in residential buildings. HES provides a shipment-weighted nominal efficiency for different types of heating and cooling systems for years between 1970 and $2010^{18}$. The second is an EIA report that characterizes major residential and commercial heating, cooling, and water heating equipment installed between 2009 and $2015^{19}$. It is worth noting that we used the "Advanced Case" of EIA projections for HVAC technologies, which may be inconsistent with assumptions for the projected levels of warming in RCP 8.5, as it assumes some increased market incentives and federal R\&D compared to the standard reference scenario. However, the difference between the advanced case and reference case in the EIA projections for HVAC equipment are rather small, resulting in only a few percentage points higher efficiencies for most equipment. Given the difficulties in accurately projecting any kind of appliance/equipment efficiencies and uptake, we doubt that these differences present an unreasonable set of assumptions. We also used estimates of equipment life expectancy for each system type to predict the efficiency of heating and cooling systems for 2012 in older home vintages that were likely to have equipment replaced by modern equipment (at the time of replacement) between the year of construction and the model year (2012) (Table S8). We used the same assumptions for heating and cooling thermostat 
set points based on climate zone as those used in Fazli and Stephens (2018) ${ }^{1}$ (using data from the 2009 U.S. DOE RECS ${ }^{5}$, as shown in Table S9.

Table S8. Assumed nominal efficiency of heating and cooling equipment for different vintages of construction in the 2010s model set

\begin{tabular}{|c|c|c|c|c|c|c|c|c|}
\hline \multicolumn{2}{|c|}{ Equipment types } & Unit & Life expectancy & $<1950$ & $\begin{array}{l}1950- \\
1969\end{array}$ & $\begin{array}{l}1970- \\
1989\end{array}$ & $\begin{array}{l}1990- \\
2009\end{array}$ & $\begin{array}{l}2010- \\
2015\end{array}$ \\
\hline \multirow{7}{*}{$\begin{array}{l}\text { Heating } \\
\text { systems }\end{array}$} & Furnace - gas & $\begin{array}{c}\text { AFUE } \\
(\%)\end{array}$ & $16-27$ & 78 & 78 & 78 & 83 & 85 \\
\hline & Furnace - oil & $\begin{array}{c}\text { AFUE } \\
(\%)\end{array}$ & $20-33$ & 76 & 76 & 76 & 80 & 81 \\
\hline & $\begin{array}{l}\text { Furnace - } \\
\text { electric }\end{array}$ & $\begin{array}{l}\text { AFUE } \\
(\%)\end{array}$ & $15-30$ & 98 & 98 & 98 & 98 & 98 \\
\hline & Boiler - gas & $\begin{array}{c}\text { AFUE } \\
(\%)\end{array}$ & $20-30$ & 75 & 75 & 75 & 80 & 84 \\
\hline & Boiler - oil & $\begin{array}{l}\text { AFUE } \\
(\%)\end{array}$ & $18-28$ & 75 & 75 & 75 & 83 & 83 \\
\hline & Heat pump & HSPF & $9-22$ & 7.4 & 7.4 & 7.4 & 7.4 & 8.1 \\
\hline & $\begin{array}{l}\text { Unit heater - } \\
\text { electric }\end{array}$ & $-(\%)$ & $15-30$ & 100 & 100 & 100 & 100 & 100 \\
\hline \multirow{3}{*}{$\begin{array}{l}\text { Cooling } \\
\text { systems }\end{array}$} & Heat pump & SEER & $9-22$ & 12 & 12 & 12 & 12 & 14 \\
\hline & $\begin{array}{l}\text { Central air } \\
\text { conditioner }\end{array}$ & SEER & $11-25$ & 12 & 12 & 12 & 12 & 14 \\
\hline & $\begin{array}{l}\text { Room air } \\
\text { conditioner }\end{array}$ & EER & $6-13$ & 10 & 10 & 10 & 10 & 11 \\
\hline
\end{tabular}

Overall, the representative home model set consists of $\sim 49 \%$ detached homes, $\sim 36 \%$ attached homes, $11 \%$ apartments, and $\sim 3 \%$ manufactured homes. Residences were distributed approximately evenly between the first four categories of construction vintage (i.e., $22 \%, 21 \%, 26 \%$, and $25 \%$ for homes built before 1950, 1950-1969, 1970-1980, and 1990-2009, respectively), and only 6\% of the homes were constructed in the fifth category (2010-2015). Just over half (51\%) of the single-family homes have a basement and $49 \%$ of have slab or crawlspace foundations. Among single-family homes with basements, $66 \%$ of them have a finished (conditioned) basement and the rest have unfinished basements. Further, central forced air is the dominant type of heating and cooling system, with $75 \%$ coverage. Most of the representative model homes $(68 \%)$ use gas as the main heating fuel, while $31 \%$ of the housing units use electric as the main heating fuel. Only $\sim 1 \%$ of the homes use oil for heating. Conversely, $66 \%$ of homes use electricity as the main source for stoves while the rest using natural gas.

Table S9. Assumptions for heating and cooling thermostat set points by climate zone based on data from 2009 RECS

\begin{tabular}{|c|c|c|c|}
\hline Climate zone & Cities & $\begin{array}{c}\text { Heating set point } \\
\left({ }^{\circ} \mathbf{C}\right)\end{array}$ & $\begin{array}{c}\text { Cooling set point } \\
\left({ }^{\circ} \mathbf{C}\right)\end{array}$ \\
\hline Hot-dry/mixed-dry & Los Angeles, Phoenix & 19.6 & 24.5 \\
\hline Hot-humid & $\begin{array}{c}\text { Atlanta, Corpus Christi, Dallas, } \\
\text { Miami }\end{array}$ & 20.5 & 24.3 \\
\hline Mixed-humid & $\begin{array}{c}\text { Birmingham, Cincinnati, } \\
\text { Nashville, New York, St. Louis, } \\
\text { Washington }\end{array}$ & 19.7 & 22.0 \\
\hline Very cold/cold & $\begin{array}{c}\text { Boston, Buffalo, Chicago, } \\
\text { Denver, Minneapolis, Seattle, } \\
\text { Worcester }\end{array}$ & 18.6 & 23.0 \\
\hline
\end{tabular}


2. Updating the nationally representative set of combined building energy and indoor air quality (IAQ) models for U.S. residences in the $\underline{2050 \mathrm{~s}}$

Next, we updated the set of combined building energy and indoor air quality (IAQ) models from the 2010s to represent the majority of the U.S. residential building stock in the 2050s, as described below.

\subsection{Population demography changes}

Several methods have been developed for making future population projections, including trend extrapolation, cohort-component, structural models, microsimulation, and spatial diffusion ${ }^{20-22}$. National projections are usually done with the cohort-component model in which the initial population is projected into the future by adding new births, subtracting deaths, adding people moving into the country (immigrants), and subtracting people moving out (emigrants) ${ }^{23}$. We rely on state-level population projection data for the year 2050 provided by ProximityOne, which develops geodemographic-economic data and projections ${ }^{24}$ using the cohort-component method along with U.S. Census Bureau data ${ }^{25}$ to estimate future populations for U.S. states, metropolitan areas, and counties. The total projected U.S. population in 2050 is 394,771,644 (Table S10). The population distribution among the 9 U.S. Census Division indicates that the Pacific division will have the highest population growth and the East North Central division is predicted to have the least amount of population growth by 2050 .

Table S10. U.S. population projection among Census Divisions in
\begin{tabular}{|c|c|c|}
\hline Census Divisions & $\begin{array}{c}\text { Population in } \\
\mathbf{2 0 5 0}\end{array}$ & $\begin{array}{c}\text { Percentage increase } \\
\text { compared to 2015 }\end{array}$ \\
\hline New England & $15,723,793$ & $7 \%$ \\
\hline Middle Atlantic & $43,038,658$ & $4 \%$ \\
\hline East North Central & $48,214,021$ & $3 \%$ \\
\hline West North Central & $24,423,686$ & $16 \%$ \\
\hline South Atlantic & $83,799,698$ & $32 \%$ \\
\hline East South Central & $21,103,339$ & $12 \%$ \\
\hline West South Central & $56,530,224$ & $45 \%$ \\
\hline Mountain & $34,062,572$ & $45 \%$ \\
\hline Pacific & $67,875,653$ & $29 \%$ \\
\hline Total & $\mathbf{3 9 4 , 7 7 1 , 6 4 4}$ & \\
\hline
\end{tabular}

\subsection{Changes in the residential building stock size between 2010s and 2050s}

By the 2050s, millions of new residential buildings will be added to the current housing stock and a smaller number of existing homes will go through retrofits or will be demolished. The number and location of newly constructed homes between the 2010s and 2050s were estimated using population projections for 2050s and making assumptions for demolition rates for existing residences. Additionally, existing homes that are not demolished but are renovated will undergo changes to their building envelopes and/or heating/cooling systems that can affect energy use and IAQ.

We rely on statistics from the Joint Center for Housing Studies (JCHS) at Harvard University to estimate demolition and renovation rates. The JCHS tabulated the number of remodeling projects reported by homeowners for the years between 1995 and 2015, categorized by the type of improvement project ${ }^{26}$. We considered their data on the number of insulation improvements made to residential buildings as being a reasonable indicator of those types of energy-related retrofits that are likely to alter heating and cooling needs and air infiltration (e.g., replacing kitchen countertops does not influence these factors). Using their data, we assumed that from 2015 to the 2050 s, $1.3 \%$ of all U.S. residences per year receive retrofits consistent with "insulation improvements." Using the same data source, we also distribute assumptions of these retrofitted residences across those homes built prior to 2010 (i.e., we assume new homes built after 
2010 do not receive substantive retrofits by the 2050s) (Table S11). For existing homes that receive retrofits, we assumed that the air infiltration rate is decreased by $25 \%$, as an approximate midpoint between $20 \%$ and $35 \%$ reported in ${ }^{27}$ and between $13 \%$ and $40 \%$ reported in ${ }^{28,29}$ for standard energy retrofits (deep energy retrofits are not considered), and that ceiling insulation will be upgraded to IECC 2020s era requirements for thermal performance (which varies regionally). We also assumed that the retrofitted homes will replace their HVAC system with more efficient systems, as discussed in Section 2.3 of this SI.

Table S11. Assumed distribution of building retrofits between 2010s and 2050s among four vintages of existing homes

\begin{tabular}{|c|c|c|c|}
\hline Year Built & $\begin{array}{c}\text { Homeowners } \\
\text { Reporting Projects } \\
\text { (000s) in 2015 }\end{array}$ & $\begin{array}{c}\text { Percentage of } \\
\text { reporting projects }\end{array}$ & $\begin{array}{c}\text { Percentage of reporting } \\
\text { projects distributed } \\
\text { between four year built }\end{array}$ \\
\hline $\begin{array}{c}\text { Before } \\
\mathbf{1 9 5 0}\end{array}$ & 3,751 & $\sim 17 \%$ & $17 \%$ \\
\hline $\mathbf{1 9 5 0 - 1 9 7 0}$ & 4,826 & $\sim 22 \%$ & $23 \%$ \\
\hline $\mathbf{1 9 7 0 - 1 9 9 0}$ & 6,343 & $\sim 29 \%$ & $30 \%$ \\
\hline $\mathbf{1 9 9 0 - 2 0 1 0}$ & 6,514 & $\sim 30 \%$ & $30 \%$ \\
\hline $\mathbf{2 0 1 0 - 2 0 1 9}$ & 503 & $\sim 2 \%$ & - \\
\hline Total & 21,937 & $\sim 100 \%$ & $100 \%$ \\
\hline
\end{tabular}

For housing unit demolition rates, we rely on a report by the U.S. EIA, which stated that a reasonable assumption for the survival rate (i.e., the percentage of households that are present in the current projection year that were also present in the preceding year) is equal to $99.7 \%$ for single-family homes, $99.5 \%$ for multi-family homes (i.e., apartments), and $96.6 \%$ for mobile homes ${ }^{30}$. For simplicity, we assumed $99.7 \%$ survival rate for all residential buildings in our model set, regardless of building type. Table S12 demonstrates the number of residential buildings before and after applying the demolition and retrofit rates to the existing buildings and considering the new residences built after 2015 .

Table S12. Number of dwellings in 2050 considering demolition, retrofit and new constructions

\begin{tabular}{|c|c|c|c|c|}
\hline $\begin{array}{c}\text { \# of existing } \\
\text { dwellings }\end{array}$ & $\begin{array}{c}\text { Based on } \\
\text { RECS 2015 }\end{array}$ & $\begin{array}{c}\text { After } \\
\text { Demolition } \\
\text { in 2050s }\end{array}$ & $\begin{array}{c}\text { \# of homes w/ } \\
\text { retrofit in 2050s }\end{array}$ & $\begin{array}{c}\text { \# of homes w/o } \\
\text { retrofit in 2050s }\end{array}$ \\
\hline Before 1950 & $21,134,084$ & $9,335,092$ & $7,383,729$ & $1,951,364$ \\
\hline $\mathbf{1 9 5 0 - 1 9 6 9}$ & $24,750,277$ & - & $9,989,750$ & $14,760,527$ \\
\hline $\mathbf{1 9 7 0 - 1 9 8 9}$ & $34,278,233$ & - & $13,030,109$ & $21,248,124$ \\
\hline $\mathbf{1 9 9 0 - 2 0 0 9}$ & $35,793,026$ & - & $13,030,109$ & $22,762,917$ \\
\hline $\begin{array}{c}\text { \# of future } \\
\text { dwellings }\end{array}$ & $\begin{array}{c}\text { Until 2015 } \\
\text { (RECS 2015) }\end{array}$ & $\begin{array}{c}\text { New } \\
\text { additions } \\
\text { after 2015 }\end{array}$ & $\begin{array}{c}\text { Demolished } \\
\text { homes } \\
\text { replacements }\end{array}$ & Total \# of homes \\
\hline $\mathbf{2 0 1 0 - 2 0 2 9}$ & $2,249,961$ & $12,233,686$ & $5,208,986$ & $19,692,633$ \\
\hline $\mathbf{2 0 3 0 - 2 0 5 0}$ & - & $17,225,280$ & $6,590,006$ & $23,815,285$ \\
\hline
\end{tabular}

Similar to the approach for the 2015 housing stock model, 2 or 3 metropolitan areas are selected to represent each U.S. Census Division. The total number of dwellings that were modeled for 2050s was 147,664,557 homes. This number of homes was calculated using the dwelling-weighted values from IECC 2015 and subtracting demolished homes from the number of the oldest vintage homes and adding newly constructed homes between 2015 and 2050 to meet the needs of both additional population growth in the future and replacement of demolished homes. Later, these homes are distributed between the 19 representative cities using the division covered percentages used for population distribution in 2015. Table S13 shows the distribution of both population and dwellings among the 19 representative cities in 2050s. 
Table S13. Population and dwelling projection for 19 cities in 2050

\begin{tabular}{|c|c|c|}
\hline Cities & $\begin{array}{c}\text { U.S. Population } \\
\mathbf{2 0 5 0}\end{array}$ & \# of Dwellings \\
\hline Atlanta, GA & $28,742,358$ & $9,370,863$ \\
\hline Birmingham, AL & $2,961,828$ & $4,079,342$ \\
\hline Boston, MA & $5,846,234$ & $5,785,446$ \\
\hline Buffalo, NY & $10,830,212$ & $2,802,700$ \\
\hline Chicago, IL & $43,145,645$ & $16,317,367$ \\
\hline Cincinnati, OH & $6,390,113$ & $8,846,834$ \\
\hline Corpus Christi, TX & $9,915,130$ & $15,377,257$ \\
\hline Dallas/Fort Worth, TX & $39,660,520$ & $12,552,199$ \\
\hline Denver, CO & $19,064,891$ & $5,998,087$ \\
\hline Los Angeles, CA & $50,530,587$ & $12,607,509$ \\
\hline Miami, FL & $30,444,867$ & $1,092,134$ \\
\hline Minneapolis, MN & $9,251,777$ & $6,539,632$ \\
\hline Nashville, TN & $6,910,932$ & $2,771,385$ \\
\hline New York, NY & $37,954,528$ & $6,250,390$ \\
\hline Phoenix, AZ & $16,974,600$ & $18,712,217$ \\
\hline Seattle, WA & $20,539,155$ & $3,581,733$ \\
\hline St. Louis, MO & $13,149,621$ & $4,261,465$ \\
\hline Washington, DC & $40,960,364$ & $6,497,879$ \\
\hline Worcester, MA & $1,498,281$ & $4,220,119$ \\
\hline Total & $\mathbf{3 9 4 , 7 7 1 , 6 4 4}$ & $\mathbf{1 4 7 , 6 6 4 , 5 5 7}$ \\
\hline & & \\
\hline & & \\
\hline
\end{tabular}

Furthermore, based on the RECS 2015 dataset, the floor area of newer single-family homes in the U.S. is, on average, greater than older homes. We estimated the average floor area of single-family homes in 2020 (to represent homes built between 2010-2030) and 2040 (to represent homes built between 2030-2050) by linear projection of historical trends in average floor areas (Figure S4).

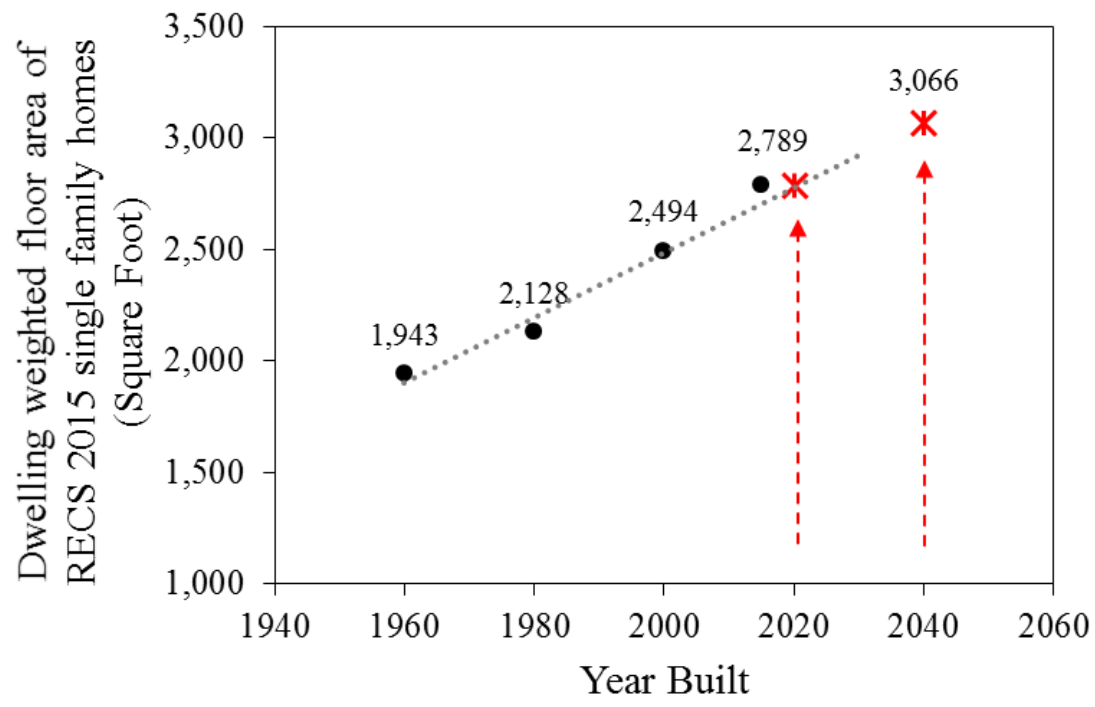

Figure S4. Floor area of single family homes in 2020 and 2040 estimated using historical RECS 2015 data 


\subsection{Changes in the residential building stock characteristics between 2010s and 2050s}

Next, we defined two new categories of building vintages to represent homes built between the 2010s and 2050s: those built between 2015-2030 (which we represent as homes built in approximately 2020) and those built between 2030-2050 (which we represent as homes built in approximately 2020). We used projections of statewide adoption of future International Energy Conservation Codes (IECC) in each climate zone for these two representative years (i.e., 2020 and 2040) to define future housing stock characteristics such as insulation levels for exterior walls, roofs, and floors, window U-values and solar heat gain coefficients (SHGC), and envelope air leakage. A list of home characteristics for each construction year (i.e. >1950, 1950-1970, 1970-1990, 1990-2010, 2010-2030, 2030-2040) and city is provided in the Appendix of this SI (Table A-5). Figure S5 shows the projection of IECC minimum requirements for residential buildings, including ceiling, wood-frame wall, and floor R-values, envelope airtightness $\left(\mathrm{ACH}_{50}\right)$, and U-values and SHGC for fenestration. To complete these projections, we compared the energy code adoption trends from 2009-2018 in the 19 states represented by our model set and forecasted code adoption by each state in future years using an approach similar to that described in ${ }^{31}$. IECC adoption in different states was categorized as "very slow," "moderate," and "timely" based on historical data.
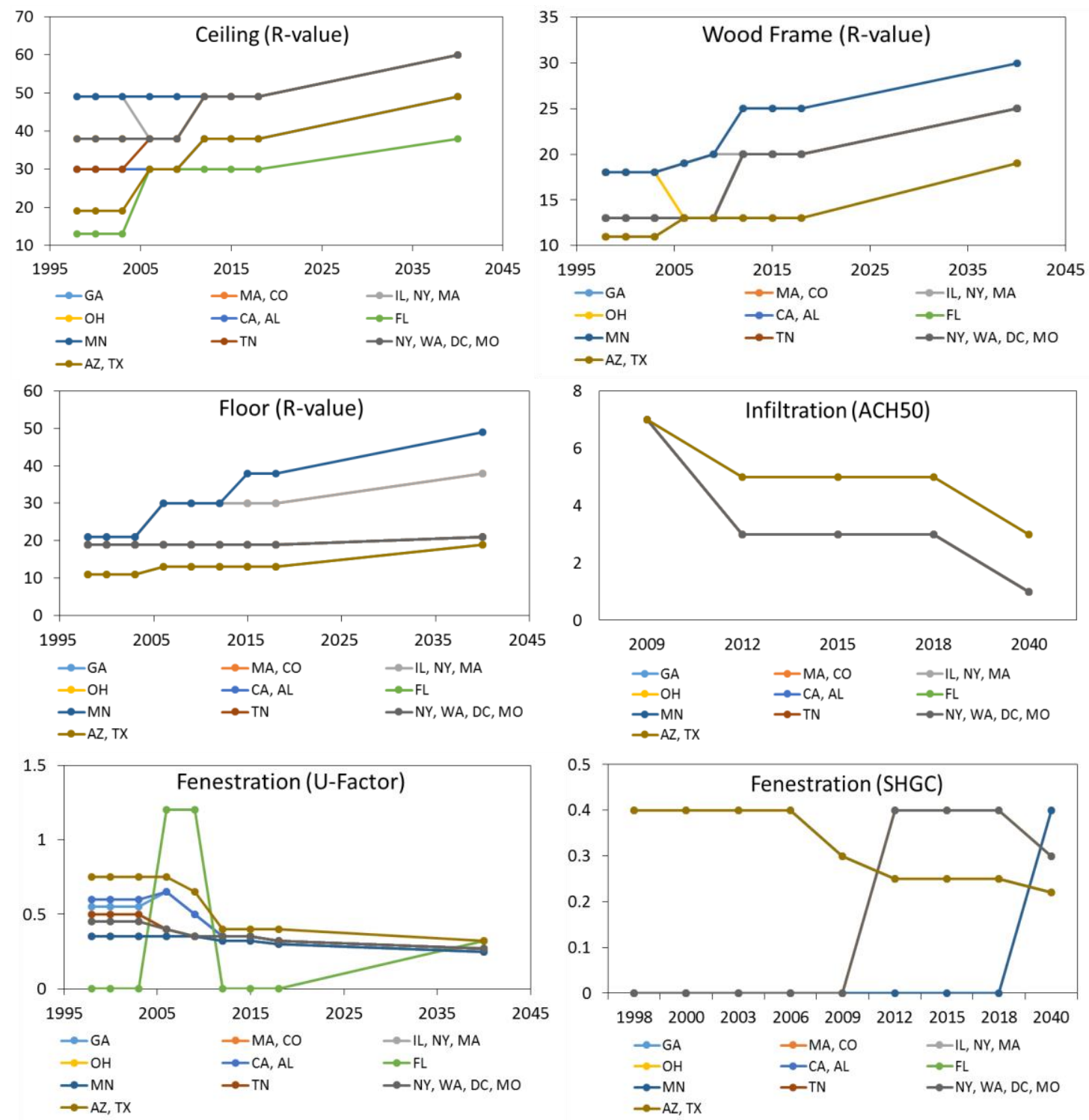

Figure S5. Projection of IECC minimum requirements for residential buildings 
Table S14 summarizes which year of future IECC each of the 19 modeled locations is projected to adopt by 2020 and 2040 .

Table S14. Projected residential IECC adoption by 2020 and 2040

\begin{tabular}{|c|c|c|c|c|}
\hline Location & $\begin{array}{l}\text { Adoptio } \\
\text { n } \\
\text { lag } \\
\text { (years) }\end{array}$ & $\begin{array}{l}\text { Adoptio } \\
\text { n } \\
\text { rate } \\
\text { class }\end{array}$ & $\begin{array}{l}\text { Projected } \\
\text { IECC, } \\
2020\end{array}$ & $\begin{array}{l}\text { Projected } \\
\text { IECC, } \\
2040\end{array}$ \\
\hline Atlanta, GA & 7 year & $\begin{array}{l}\text { Very } \\
\text { slow }\end{array}$ & 2012 & 2033 \\
\hline Birmingham, AL & 4 year & $\begin{array}{l}\text { Moderat } \\
\mathrm{e}\end{array}$ & 2015 & 2036 \\
\hline Boston, MA & 1 year & Timely & 2018 & 2039 \\
\hline Buffalo, NY & 4 year & $\begin{array}{l}\text { Moderat } \\
\text { e }\end{array}$ & 2015 & 2036 \\
\hline Chicago, IL & 1 year & Timely & 2018 & 2039 \\
\hline Cincinnati, $\mathbf{O H}$ & 7 year & $\begin{array}{l}\text { Very } \\
\text { slow }\end{array}$ & 2012 & 2033 \\
\hline $\begin{array}{l}\text { Corpus Christi, } \\
\text { TX }\end{array}$ & 4 year & $\begin{array}{l}\text { Moderat } \\
\text { e }\end{array}$ & 2015 & 2036 \\
\hline $\begin{array}{l}\text { Dallas/Fort Worth, } \\
\text { TX }\end{array}$ & 4 year & $\begin{array}{l}\text { Moderat } \\
\mathrm{e}\end{array}$ & 2015 & 2036 \\
\hline Denver, CO & - & - & 2009 & 2009 \\
\hline Los Angeles, CA & 1 year & Timely & 2018 & 2039 \\
\hline Miami, FL & 4 years & $\begin{array}{l}\text { Moderat } \\
\mathrm{e}\end{array}$ & 2015 & 2036 \\
\hline Minneapolis, MN & 4 years & $\begin{array}{l}\text { Moderat } \\
\mathrm{e}\end{array}$ & 2015 & 2036 \\
\hline Nashville, TN & 7 years & $\begin{array}{l}\text { Very } \\
\text { slow }\end{array}$ & 2012 & 2033 \\
\hline New York, NY & 4 year & $\begin{array}{l}\text { Moderat } \\
\mathrm{e}\end{array}$ & 2015 & 2036 \\
\hline Phoenix, AZ & 7 years & $\begin{array}{l}\text { Very } \\
\text { slow }\end{array}$ & 2012 & 2033 \\
\hline Seattle, WA & 1 year & Timely & 2018 & 2039 \\
\hline St. Louis, MO & 7 years & $\begin{array}{l}\text { Very } \\
\text { slow }\end{array}$ & 2012 & 2033 \\
\hline Washington, DC & 4 year & $\begin{array}{l}\text { Moderat } \\
\mathrm{e}\end{array}$ & 2015 & 2036 \\
\hline Worcester, MA & 1 year & Timely & 2018 & 2039 \\
\hline
\end{tabular}

Similarly, we used a recent EIA report on residential and commercial building technology forecasts ${ }^{19}$ to project HVAC system characteristics (i.e., fuel type and nominal efficiency) for the two new categories of homes built between the 2010s and 2050s, again using 2020 and 2040 to represent homes built between 2015-2030 and 2030-2050, respectively (Table S15). 
Table S15. Assumed type and efficiency of heating and cooling equipment for different vintages of future construction (2010s to 2050s)

\begin{tabular}{|c|c|c|c|c|}
\hline Equipment Type & Equipment & Fuel & $\mathbf{2 0 1 0 - 2 0 3 0}$ & $\mathbf{2 0 3 0 - 2 0 5 0}$ \\
\hline & Furnace & Gas & $92 * / 85^{* *}$ & $95^{*} / 85^{* *}$ \\
\cline { 2 - 5 } & Oil & 83 & 85 \\
\cline { 2 - 5 } Heating System & Boiler & Gas & 90 & 94 \\
\cline { 2 - 5 } & $\begin{array}{c}\text { Heat pump - } \\
\text { HSPF }\end{array}$ & Eil & 84 & 87 \\
\cline { 2 - 5 } & $\begin{array}{c}\text { Heat pump - } \\
\text { SEER }\end{array}$ & Electricity & 8.6 & 9 \\
\hline \multirow{2}{*}{ Cooling System } & AC & Electricity & $14 * / 14.4 * *$ & $15.5 * / 16^{* *}$ \\
\hline & RC & Electricity & 12.3 & 13 \\
\hline
\end{tabular}

* Equipment efficiency for cities located in northern U.S. climate zones

** Equipment efficiency for cities located in the rest of the country

Moreover, the approach we took in assuming the predominant fuel type for future homes was to duplicate the same predominant fuel type present in the most recent home vintages (HC5: i.e., 2010-2015 for the baseline model set and 2010-2030 for the future model set). This was based on RECS 2015 and assumes that the most prevalent fuel type in 2015 continues to be the case into the future, which does not consider aggressive fuel changes (such as electrification) but rather represents a conservative business-asusual approach.

\section{Energy and indoor air quality (IAQ) modeling of the current and future housing stock}

After defining the building stock model sets, we used the automated REIAQ workflow to run energy and IAQ simulations for the current and future housing stock model set using input data for 2012 and the mid2050s, respectively.

\subsection{Hourly meteorological data in 2010s and 2050s}

We used actual meteorological year (AMY) data for each of the modeled 19 cities for the year 2012, which was the most recent year for which hourly outdoor pollutant data were also available at the time of the development of the original REIAQ model set. Historical weather files are purchased from White Box Technologies for all 19 cities ${ }^{10}$. For the future climate scenario, we used hourly outputs from a previous study that predicted future hourly weather conditions in the 2050s using the Weather Research and Forecasting (WRF) Model $^{32}$ with a $12 \mathrm{~km}$ by $12 \mathrm{~km}$ resolution following assumptions of the Representative Concentration Pathways (RCP) 8.5 from the Intergovernmental Panel on Climate Change (IPCC) Fifth Assessment Report (AR5) ${ }^{33}$. RCP 8.5 used to be recognized as a "high" emissions scenario, assuming an increase in greenhouse gas emissions; however, recently RCP 8.5 has become known more the "businessas-usual" scenario since emissions continue to increase globally ${ }^{34}$. Figure S6 shows predicted changes in the annual distribution of hourly dry bulb temperature from 2012 (AMY) to 2050s (WRF RCP 8.5 predictions in $\left.{ }^{33}\right)$. For reference, the average increase in ambient dry bulb temperatures across our 19 model cities is $\sim 2.5^{\circ} \mathrm{C}$ between 2012 and 2050 s. 


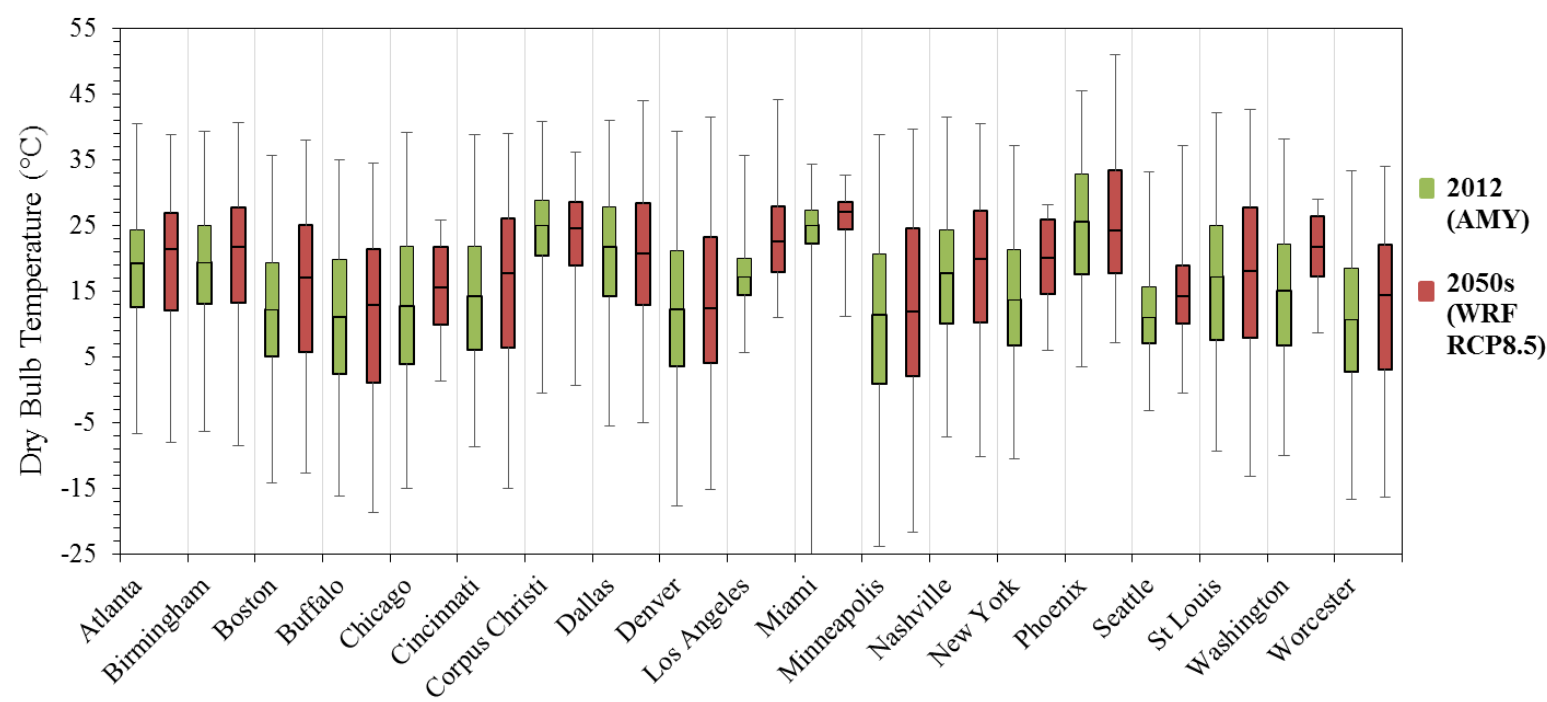

Figure S6. Distributions of hourly dry bulb temperatures in 2012 (using AMY) and 2050s (using WRF with IPCC RCP 8.5 ${ }^{33}$ )

\subsection{Hourly outdoor pollutant concentration data in 2010s and 2050s}

Similarly, we used the same hourly outdoor pollutant data for the year 2012 that was used in our previous study ${ }^{1}$. Briefly, hourly outdoor pollutant data for $\mathrm{PM}_{2.5}, \mathrm{NO}_{2}$, and $\mathrm{O}_{3}$ in each location were culled from the U.S. EPA Air Quality System (AQS) online repository for each of the 19 representative model locations for the year $2012^{9}$. Data were visually inspected for missing values and, when there were gaps in the hourly data, hourly data from the next closest monitoring station were selected if available. If small gaps still remained and the number of missing data resulted in less than $95 \%$ of the total expected number of hourly data points, then linear interpolation was used to estimate any missing observations. Approximations of hourly outdoor ultrafine particle (UFP) concentrations were made based on associations with $\mathrm{NO}_{\mathrm{x}}$ concentrations using correlations reported by Azimi et al. ${ }^{35}$. Ambient concentrations of volatile organic compounds (VOCs) and aldehydes were assumed to be constant throughout the year, as hourly data are not widely available for these compounds. The geometric mean ambient concentrations from 48-h air samples collected in about 300 homes in the Relationships of Indoor, Outdoor, and Personal Air (RIOPA) study were used as these constant ambient concentrations ${ }^{36}$, including $3.9,2.3,0.21,0.1,0.53$, and $0.39 \mathrm{ppb}$ for formaldehyde, acetaldehyde, acrolein, 1,3-butadiene, benzene, and 1,4-dichlorobenzene, respectively.

For the future model years ( 2050s), we used predictions of future hourly pollutant concentrations from applications of the Community Multi-Scale Air Quality (CMAQ) modeling system version 5.0 from Sun et al. (2015) ${ }^{37}$. CMAQ is a three-dimensional comprehensive atmospheric chemistry and transport model developed by the EPA and the community ${ }^{38,39}$. Sun et al. (2015) used the same $12 \mathrm{~km}$ by $12 \mathrm{~km}$ spatial resolution as their WRF models for their CMAQ simulations to predict both hourly future meteorological conditions and pollutant concentrations, including $\mathrm{PM}_{2.5}, \mathrm{NO}_{2}, \mathrm{O}_{3}$, and several VOCs and aldehydes (i.e., formaldehyde, acetaldehyde, and benzene), again assuming RCP 8.5. We again estimated UFP concentrations assuming correlations between UFP and $\mathrm{NO}_{\mathrm{x}}$ concentrations continue to hold.

Figure S7 shows the resulting annual average outdoor concentrations of these pollutants, averaged across all 19 model locations, in the current climate scenario of 2012 (same as in ${ }^{1}$ ) and in the future climate scenario of $\sim 2050$ s. Not surprisingly, ambient concentrations of each pollutant, except $\mathrm{O}_{3}$, is expected to decrease by the 2050 s compared to 2012 . 

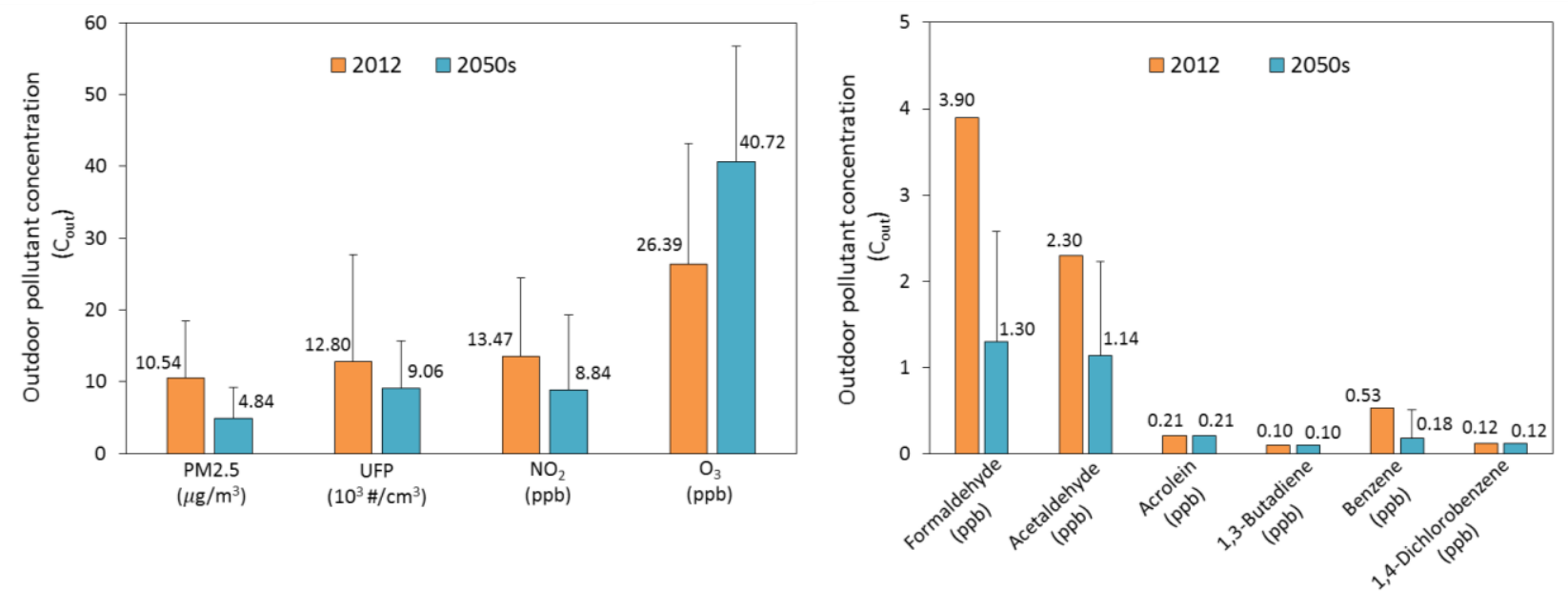

Figure S7. Annual average outdoor concentrations of several pollutants, averaged across all 19 cities, in 2012 (from ${ }^{1}$ ) and 2050s (from ${ }^{37}$ )

Figure $\mathrm{S} 8$ shows predicted changes in the annual distribution of hourly outdoor concentration of $\mathrm{PM}_{2.5}$, UFP, $\mathrm{NO}_{2}$, and $\mathrm{O}_{3}$ across the 19 model cities from 2012 (EPA, AQS) to 2050s (WRF-CMAQ, RCP 8.5; data were extracted from model outputs from Sun et al. $(2015)^{37}$ ). 

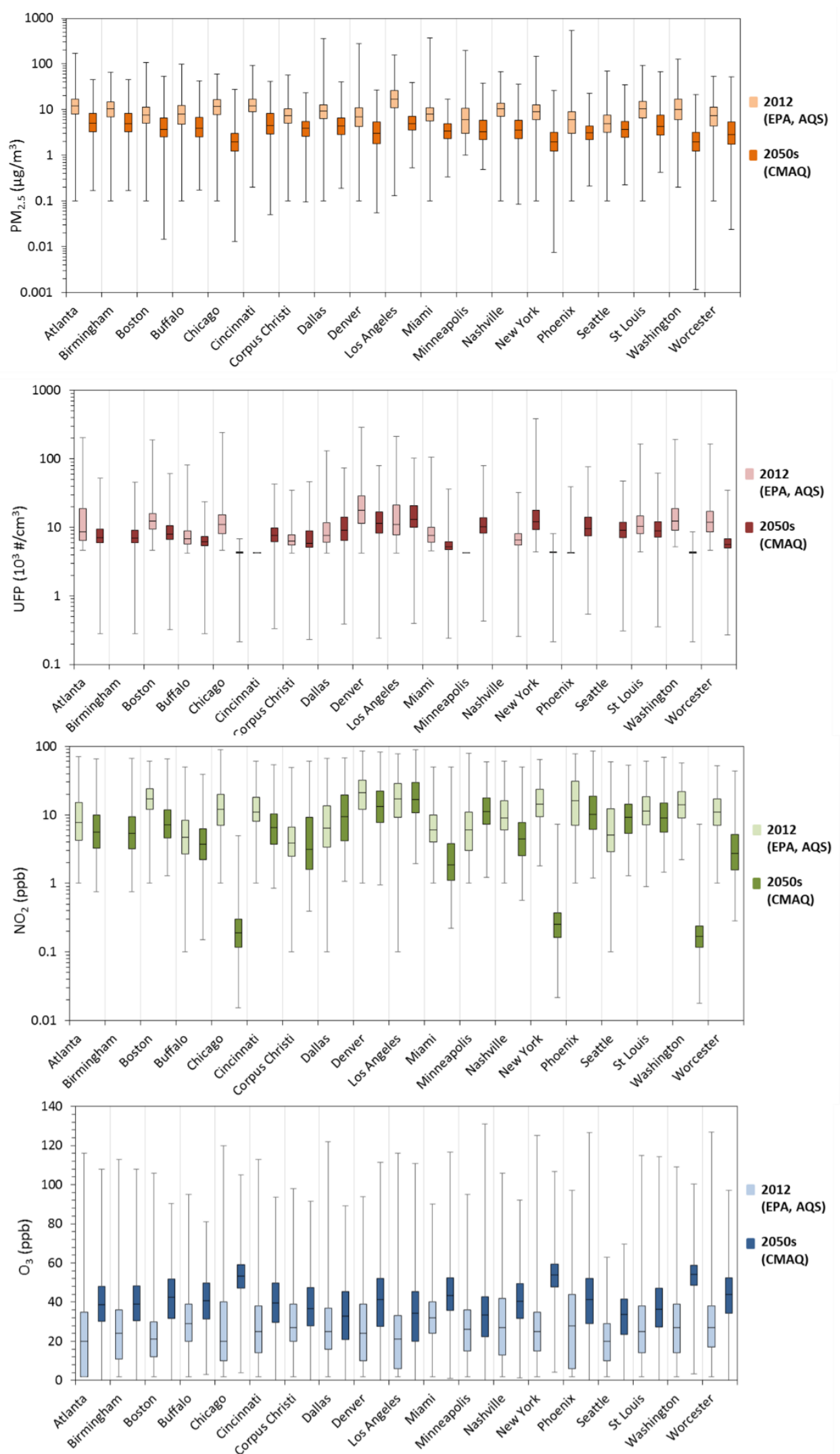

Figure S8. Distributions of hourly Outdoor concentration of $\mathrm{PM}_{2.5}, \mathrm{UFP}, \mathrm{NO}_{2}$, and $\mathrm{O}_{3}$ from 2012 (EPA, $\mathrm{AQS}^{9}$ ) to 2050s (WRF-CMAQ, RCP 8.5 ${ }^{37}$ ) across 19 model cities 


\subsection{Applying the energy and IAQ models}

Energy and IAQ model application follows the same approach as in our previous study ${ }^{1}$, with nearly identical model inputs other than changes in the building stock models and future weather and climate data. Briefly, the 217 model hsome geometries that represent $\sim 80 \%$ of homes in the U.S. in the 2010s were first built in BEopt to generate 4123 unique XML files representing over 4123 homes across 19 cities, which were then used to generate EnergyPlus input files. EnergyPlus simulations were run for each of these home and location combinations, and then python scripts were used to gather hourly outputs from the EnergyPlus to generate hourly estimates of heating and cooling energy use, infiltration/ventilation rates, HVAC Oruntimes, and other parameters. Relevant parameters from these simulations were then fed to a custom mass balance model to calculate time-varying concentrations of several pollutants of both indoor and outdoor origin that have been previously identified as being of most concern to chronic health impacts across the U.S. residential building stock. Indoor pollutant concentrations at each time step $\left(t_{n}\right)$ were then estimated using Equation S5.

$$
\begin{aligned}
C_{\text {in }}\left(t_{n}\right)=C_{\text {in }}( & \left.t_{n-1}\right)+\Delta t\left[\left(P \lambda_{\text {inf }}\left(t_{n-1}\right)+\lambda_{\text {nat }}\left(t_{n-1}\right)\right) C_{\text {out }}\left(t_{n-1}\right)+\frac{E\left(t_{n-1}\right)}{V}-\left(\lambda_{\text {inf }}\left(t_{n-1}\right)\right.\right. \\
& \left.+\lambda_{\text {nat }}\left(t_{n-1}\right)\right) C_{\text {in }}\left(t_{n-1}\right)-\frac{Q_{\text {exhaust }}\left(t_{n-1}\right)}{V} C_{\text {in }}\left(t_{n-1}\right)-\beta C_{\text {in }}\left(t_{n-1}\right) \\
& \left.-f_{\text {filt }}\left(t_{n-1}\right) \frac{\eta_{\text {filt }} Q_{\text {filt }}\left(t_{n-1}\right)}{V} C_{\text {in }}\left(t_{n-1}\right)-k C_{\text {terp }} C_{\text {in }}\left(t_{n-1}\right)\right]
\end{aligned}
$$

Where $C_{i n}=$ the indoor concentration of any airborne pollutant $\left(\# \mathrm{~m}^{-3}\right.$ or $\mu \mathrm{g} \mathrm{m}^{-3}$ for particles; ppb or $\mu \mathrm{g} \mathrm{m}^{-3}$ for gases), $P=$ the penetration factor of the building envelope for a particular pollutant (dimensionless, ranging from 0 to 1$), \lambda_{\text {inf }}=$ the air change rate due to infiltration alone $\left(\mathrm{h}^{-1}\right), \mathrm{C}_{\text {out }}=$ the outdoor pollutant concentration (\# $\mathrm{m}^{-3}$ or $\mu \mathrm{g} \mathrm{m}^{-3}$ for particles; ppb or $\mu \mathrm{g} \mathrm{m}^{-3}$ for gases), $\mathrm{E}=$ the wholehouse indoor emission rate of a pollutant $\left(\mu \mathrm{g} \mathrm{m}^{-3}, \# \mathrm{~h}^{-1}\right.$, or $\left.\mathrm{ppb} \mathrm{h}^{-1}\right), \mathrm{V}=$ the volume of the home $\left(\mathrm{m}^{3}\right)$, $\mathrm{Q}_{\text {exhaust }}=$ the airflow rate of any mechanical exhaust ventilation system $\left(\mathrm{m}^{3} \mathrm{~h}^{-1}\right), \beta=$ the first-order indoor loss rate of the pollutant by deposition to surfaces and/or surface reactions $\left(h^{-1}\right), \eta_{\text {filt }}=$ the pollutant removal efficiency of a filter installed the HVAC system if applicable (dimensionless, ranging from 0 to $1), Q_{\text {filt }}=$ the airflow rate through the central HVAC filter if applicable $\left(\mathrm{m}^{3} \mathrm{~h}^{-1}\right), \mathrm{f}_{\text {filt }}=$ the fractional runtime of the HVAC system if applicable (dimensionless, ranging from 0 to 1 ), $\mathrm{k}=$ the bimolecular reaction rate constant between two gas-phase compounds $\left(\mathrm{m}^{3} \mu \mathrm{g}^{-1} \mathrm{~h}^{-1}\right.$ or $\left.\mathrm{ppb}^{-1} \mathrm{~h}^{-1}\right)$, $\mathrm{C}_{\text {terp }}=$ the concentration of a reactant ( $\mu \mathrm{g} \mathrm{m}^{-3}$ or ppb), $t_{n}$ is the current time step $(h)$, and $t_{n-1}$ is the previous time step (h).

We made several assumptions for both constant (time-averaged) and intermittent indoor emissions of pollutants (e.g., median constant emission rates of VOCs and aldehydes and once-per-day UFP, PM 2.5 , and $\mathrm{NO}_{2}$ emissions during cooking), each the same as in our previous study ${ }^{1}$. Geometric mean whole-house emission rates for VOCs and aldehydes were taken from recent estimates based on the Relationships of Indoor, Outdoor, and Personal Air (RIOPA) database made in Waring (2014) ${ }^{40}$. Transient $\mathrm{PM}_{2.5}, \mathrm{NO}_{2}$, and UFP emission rates were assumed to follow scripted human activity patterns with typical source-strengths for the most common sources found in the literature. $\mathrm{PM}_{2.5}$, UFP, and $\mathrm{NO}_{2}$ emissions were assumed to be generated only from cooking, which was assumed to occur one hour per day, every day, in the evening (6:00 pm - 7:00 pm) and are shown in Table S16. We assumed $\mathrm{PM}_{2.5}$ emissions were solely from cooking and that $\mathrm{PM}_{2.5}$ emission factors do not change with the stove type. However, UFP emissions were assumed to result from both cooking and gas stove combustion; therefore, switching from gas to electric stoves reduces UFP emissions but does not eliminate them completely. Finally, $\mathrm{NO}_{2}$ emissions were assumed to result only from gas stoves and not the cooking process; thus, electric stoves were assumed to have no $\mathrm{NO}_{2}$ emissions.

Other pollutant source and loss mechanisms used in the mass balance in Equation S5 include building envelope penetration factors, indoor deposition loss rate coefficients, and HVAC filter removal efficiencies 
(if applicable). Typical values for each of these parameters were culled from the literature and are shown in Table S16 as well. The average HVAC filter was assumed to be a MERV 6; variations were not considered because only 'typical' homes are represented in the model set. All VOCs and aldehydes with outdoor sources were assumed to have penetration factors of 1 and negligible indoor deposition loss rates (except formaldehyde, which was assumed to have a decay rate of $0.34 \mathrm{~h}^{-1}{ }^{41}$ ). We assumed that HVAC filters had negligible removal efficiency for $\mathrm{O}_{3}, \mathrm{NO}_{2}$, and all VOCs and aldehydes, and sorption dynamics for VOCs and aldehydes were ignored for simplicity.

Importantly, we used the same assumptions for indoor source strengths (both intermittent and timeaveraged), pollutant penetration factors, deposition loss rate constants, and filtration efficiencies in both the current and future building stock models. We did not make any assumptions for changes in indoor source strengths in future years, primarily due to a lack of quantitative data on projections for changes in indoor emission rates over time ${ }^{42}$, and also for simplicity. Moreover, holding indoor source strengths constant allows for isolating the impacts of changing meteorological conditions, building stock characteristics, and outdoor pollutant concentrations in a future climate scenario. All homes were assumed to be non-smoking across both climate scenarios.

Similar to the method that was used in Fazli and Stephens (2018), ${ }^{1}$ the natural ventilation (i.e., window opening) schedule was assumed to vary based on the presence of central forced-air heating and cooling systems in the home models following default assumptions in BEopt. Homes with central forced-air distribution systems were assumed to allow natural ventilation 3 days per week (Mondays, Wednesdays, and Fridays) to reflect windows being opened occasionally. Homes without central forced-air heating and cooling systems were assumed to allow natural ventilation 7 days a week. Default assumptions for daily window opening in BEopt are based on the 2014 Building America House Simulation Protocols. Windows were assumed to be opened only when the outdoor air humidity ratio was less than $0.0115 \mathrm{~kg}_{\mathrm{w}} / \mathrm{kg}_{\mathrm{da}}$ and the outdoor air relative humidity was less than $70 \%$. Windows were assumed to be closed when the indoor air temperature dropped $0.5^{\circ} \mathrm{C}$ below the heating or cooling set point or if the cooling load of outdoor airflow could not maintain the cooling set point.

Predictions of time-varying pollutant concentrations were then summarized on an annual basis for each home, and finally, population-weighting factors were applied to each of the 4,123 unique home models to weight for approximately how many homes they represent across the country.

Table S16. Assumptions for source and loss mechanisms for modeled pollutants

\begin{tabular}{|c|c|c|c|c|c|}
\hline \multicolumn{2}{|c|}{ Source \& loss mechanisms } & $\mathbf{P M}_{2.5}$ & UFP & $\mathbf{O}_{3}$ & $\mathrm{NO}_{2}$ \\
\hline \multicolumn{2}{|c|}{ Penetration factor (-) } & $0.82^{43-45}$ & $0.47^{46}$ & $0.79^{47}$ & $1.0^{48}$ \\
\hline \multicolumn{2}{|c|}{ Loss rate constant $\left(\mathbf{h}^{-1}\right)$} & $0.30^{45}$ & $0.70^{49}$ & $2.8^{50}$ & $0.34^{51}$ \\
\hline \multicolumn{2}{|c|}{ Removal efficiency (-) (MERV6) } & $8 \% \%^{52,53}$ & $8 \% \%^{52,53}$ & - & - \\
\hline \multirow[b]{2}{*}{ Emission rate } & Gas stove & \multirow{2}{*}{$38.4 \frac{\mathrm{mg}}{\mathrm{hr}} 54,55$} & $1.13 \times 10^{14} \frac{\#}{\mathrm{hr}} 56$ & \multirow[b]{2}{*}{-} & $123 \frac{\mathrm{mg}}{\mathrm{hr}} 57,58$ \\
\hline & Electric stove & & $7.5 \times 10^{13} \frac{\#}{\mathrm{hr}} 56$ & & $0 \frac{\mathrm{mg}}{\mathrm{hr}}$ \\
\hline
\end{tabular}

\subsection{Predicting chronic health impacts of pollutant exposures}

The chronic health impacts of residential inhalation exposure to the modeled pollutants were estimated using a disability-adjusted life-years (DALYs) approach ${ }^{59}$ applied to the population-weighted annual average indoor pollutant concentrations. The population-weighted average pollutant concentration is based on the number of occupants per archetype building in each region. In this methodology, the total chronic health impacts on a DALY basis can be calculated by multiplying the disease incidence by the number of DALYs lost per incidence (i.e., a DALY factor), as shown in Equation S6. 


$$
D A L Y S=\left(\frac{\partial D A L Y s}{\partial \text { disease incidence }}\right) \times \Delta y_{i}
$$

Where $\Delta \mathrm{y}_{\mathrm{i}}$ is the change in annual health endpoint (disease incidence) (per person per year which has been taken from several studies.

Two methods are used to estimate DALYs ${ }^{59}$ : (1) epidemiology-based concentration-response (C-R) functions (i.e., the intake-incidence-DALY, or IND method), and (2) dose-response (D-R) functions (i.e., the intake-DALY, or ID method) that rely on data from Huijbregts et al. (2005) ${ }^{60}$. The IND approach is used for criteria pollutants (e.g., $\mathrm{PM}_{2.5}, \mathrm{NO}_{2}$, and $\mathrm{O}_{3}$ ) and the ID approach is used for all other non-criteria pollutants. DALYs were not estimated for total UFPs due to a lack of epidemiological literature for longterm exposures.

\subsubsection{Intake-incidence-DALY (IND) approach}

In the IND method, a change in disease incidence is calculated as shown in Equation S7:

$$
\Delta y_{i}=-\left(y_{0} \times\left[\exp \left(-\beta \times C_{\text {exposure }}\right)-1\right]\right) \times \text { population }
$$

Where $y_{0}$ is the baseline prevalence of illness (per person per year), $\beta$ is the coefficient of the concentration change (per $\left.\mu \mathrm{g} / \mathrm{m}^{3}\right), C_{\text {exposure }}$ is the exposure of pollutant concentration $\left(\mu \mathrm{g} / \mathrm{m}^{3}\right)$. All the input parameters for the C-R functions are assumed to be the same as a recent U.S. EPA cost-benefit analysis of the Clean Air Act ${ }^{61}$ (Table S17). Following Logue et al. ${ }^{59}$, Equation S7 was modified to account for the average fraction of time spent in residences and the resulting population-weighted annual average indoor pollutant concentrations found in residences (Equation S8).

$$
\Delta y_{i}=-\left(y_{0} \times\left[\exp \left(-\beta \times C_{\text {in }} \times P_{\text {time,indoor }}\right)-1\right]\right) \times \text { population }
$$

where $C_{i n}$ is the population weighted indoor pollutant concentration $\left(\mu \mathrm{g} / \mathrm{m}^{3}\right), P_{\text {time, indoor }}$ is the average fraction of time people spend inside residences (i.e., 70\%) ${ }^{62}$, and population is the U.S. population (i.e., the number of persons exposed). The average fraction of time of time people spend inside residences is assumed constant in current and future scenarios, primarily because of a lack of known forecasts of this

\begin{tabular}{|c|c|c|c|c|c|}
\hline Pollutant & \multicolumn{2}{|c|}{ Outcome } & $\beta$-Coefficient & $y_{0}$ & $\begin{array}{c}\partial \mathrm{DALYs} /(\partial \mathrm{disease} \\
\text { incidence) }\end{array}$ \\
\hline \multirow{3}{*}{$\mathbf{P M}_{2.5}$} & \multicolumn{2}{|c|}{ Total mortality } & 0.0058 & 0.0074 & 1.4 \\
\hline & \multicolumn{2}{|c|}{ Chronic bronchitis } & 0.091 & 0.0004 & 1.2 \\
\hline & \multicolumn{2}{|c|}{ Nonfatal stroke } & 0.025 & 0.0002 & 11.43 \\
\hline \multirow{3}{*}{$\mathrm{NO}_{2}$} & \multirow{3}{*}{$\begin{array}{c}\text { Hospital } \\
\text { admissions }\end{array}$} & $\begin{array}{l}\text { Respiratory } \\
\text { issues }\end{array}$ & 0.004 & 0.0095 & 0.0264 \\
\hline & & $\begin{array}{l}\text { Congestive } \\
\text { heart failure }\end{array}$ & 0.003 & 0.0034 & 0.0264 \\
\hline & & $\begin{array}{c}\text { Ischemic } \\
\text { heart disease }\end{array}$ & 0.003 & 0.008 & 0.0264 \\
\hline \multirow{3}{*}{$\mathbf{O}_{3}$} & \multicolumn{2}{|c|}{ Mortality } & 0.001 & 0.0077 & 1 \\
\hline & \multirow{2}{*}{$\begin{array}{c}\text { Hospital } \\
\text { admissions }\end{array}$} & Asthma & 0.003 & 0.0018 & 0.0264 \\
\hline & & Lung disease & 0.003 & 0.0021 & 0.0264 \\
\hline
\end{tabular}
parameter.

Table S17. Summary of input parameters for health impact of criteria pollutant 


\begin{tabular}{llll}
\hline $\begin{array}{c}\text { Respiratory } \\
\text { infection }\end{array}$ & 0.002 & 0.0058 & 0.0264 \\
\cline { 2 - 4 } Dysrhythmias & 0.002 & 0.0024 & 0.0264 \\
\hline
\end{tabular}

\subsubsection{Intake-DALY (ID) approach}

For the ID method, we used the equation given in Logue et al. (2012) ${ }^{59}$ in which DALYs lost are calculated using data in Huijbregts et al. (2005), which calculated human impact factors for carcinogenic and noncarcinogenic substances (Equation S9).

$$
\text { DALYs }_{\mathrm{i}}=\mathrm{C}_{\mathrm{i}} \times \mathrm{V} \times\left[\left(\frac{\partial \mathrm{DALYcancer}}{\partial \text { intake }}\right)_{\mathrm{i}} \times \mathrm{ADAF}+\left(\frac{\partial \text { DALYnoncancer }}{\partial \text { intake }}\right)_{\mathrm{i}}\right]
$$

Where $\frac{\partial \text { DALYcancer }}{\partial \text { intake }}$ and $\frac{\partial \text { DALYnoncancer }}{\partial \text { intake }}$ are the carcinogenic and non-carcinogenic mass intake-based DALYs lost per incidence respectively, $C_{i}$ is the population weighted indoor concentration $\left(\mu \mathrm{g} / \mathrm{m}^{3}\right), \mathrm{V}$ is a population weighted average air intake in the residence $\left(\mathrm{m}^{3} /\right.$ year), and ADAF is the age-dependent adjustment factor for cancer exposure (-). Both V and ADAF were computed using the combination of age distribution and age-based inhalation rates and percent of day spent at home for U.S population. Population average air intake and cancer ADAF are assumed to be $5256 \mathrm{~m}^{3} /$ year and 1.6, respectively. DALYs lost per incidence (total damage and effect factor) of selected VOCs and aldehydes for carcinogenic and noncarcinogenic human health impacts are shown in Table S18.

Table S18. Combined DALYs lost per incidence factor of selected VOCs and aldehydes for carcinogenic and non-carcinogenic damage

\begin{tabular}{ccc}
\hline \multirow{2}{*}{ Compound } & \multicolumn{2}{c}{ DDALY/2intake (year $\left.\mathbf{k g}^{\mathbf{- 1}}\right)$} \\
\cline { 2 - 3 } & Carcinogenic & $\begin{array}{c}\text { Non-carcinogenic } \\
\text { (inhalation) }\end{array}$ \\
\hline Formaldehyde & 0.76 & - \\
\hline Acetaldehyde & 0.0064 & 0.032 \\
\hline Acrolein & - & 50 \\
\hline 1,3-Butadiene & 0.003 & 0.071 \\
\hline Benzene & 0.0058 & 0.0031 \\
\hline 1,4-Dichlorobenzene & 0.0012 & 0.0019 \\
\hline
\end{tabular}

\section{SI Results}

\section{Baseline year model results (2010s)}

\subsection{Modeled annual space conditioning energy consumption in the baseline year (2012)}

Estimates of the total annual heating and cooling energy consumption (on site energy basis) for the U.S. residential building stock made using the model set for the baseline model year of 2012 are shown in Figure S9, split by fuel source, along with data reported in the 2009 and 2015 U.S. RECS. In Figure S9, 2009 EIA data are scaled to the number of homes used in the 2015 model set $(118,205,582$ dwellings) to allow for direct comparison with 2015 modeling results and EIA data. 


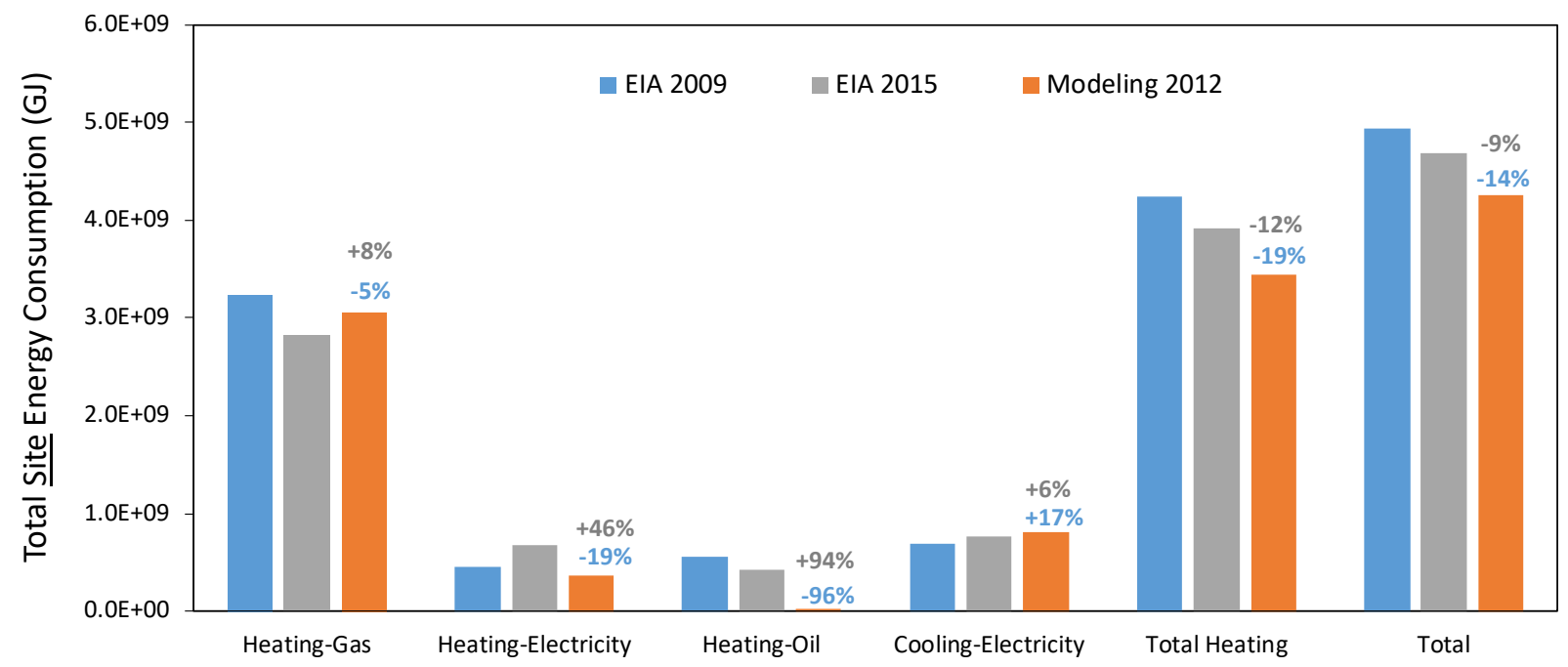

Figure S9. Comparison of total annual residential space conditioning site energy consumption from 2012 modeling vs. EIA 2009 and 2015 RECS data

The total annual space conditioning energy consumption (on a site energy basis) across all modeled U.S. residential buildings in 2012 was estimated to be $\sim 4.26 \times 10^{9} \mathrm{GJ}$, which was $\sim 14 \%$ and $\sim 9 \%$ lower than values of $\sim 4.93 \times 10^{9} \mathrm{GJ}$ and $\sim 4.68 \times 10^{9} \mathrm{GJ}$ from the 2009 and 2015 EIA data, respectively. The total annual heating energy consumption (on a site energy basis) across all modeled U.S. residential buildings in 2012 was estimated to be $\sim 3.45 \times 10^{9} \mathrm{GJ}$, which was $\sim 19 \%$ and $\sim 12 \%$ lower than values of $\sim 4.24 \times 10^{9} \mathrm{GJ}$ and $\sim 4.68 \times 10^{9}$ GJ from the 2009 and 2015 EIA data, respectively. Conversely, the total annual cooling energy consumption (on a site energy basis) in 2012 across the building stock was estimated to be $\sim 8.14 \times 10^{8} \mathrm{GJ}$, which was $\sim 17 \%$ and $\sim 6 \%$ higher than values of $\sim 6.96 \times 10^{8}$ GJ and $\sim 7.70 \times 10^{8}$ GJ from the 2009 and 2015 EIA data, respectively. The model set underpredicts heating oil energy usage because of the lack of representation of homes relying on fuel oil for heating, but the magnitudes of this end use are negligible compared to other end uses.

According to the National Oceanic Atmospheric Administration (NOAA), 2012 was the warmest year on record in the 48 continental U.S. states ${ }^{63}$. In Table S19, we compare the number of heating degree days (HDDs) and cooling degree days (CDDs) recorded for the U.S. for 2009, 2012, and 2015. The year 2012 had $\sim 16 \%$ and $\sim 9 \%$ lower HDDs compared to 2009 and 2015, respectively. If we assume a linear relationship between site energy use for heating and HDDs, accounting for these differences would result in a $~ 3 \%$ difference in site energy consumption for heating between the 2012 model results and the 2009 and 2015 EIA data. Similarly, 2012 had $20 \%$ and 2\% higher CDDs compared to 2009 and 2015. Again, if we assume a linear relationship between site energy use for cooling and CDDs, accounting for these differences would result in a $\sim 3-4 \%$ difference in site energy consumption for cooling energy consumption between the 2012 model results and the 2009 and 2015 EIA data.

Table S19. Heating degree days (HDD) and cooling degree days (CDD) for years 2009, 2012, and 2015 and their percentage differences

\begin{tabular}{|l|l|l|l|l|l|}
\hline Year & $\mathbf{2 0 0 9}$ & $\mathbf{2 0 1 2}$ & $\mathbf{2 0 1 5}$ & $\mathbf{2 0 1 2}$ vs. 2009 & 2012 vs. 2015 \\
\hline HDD & 4458 & 3754 & 4103 & $-16 \%$ & $-9 \%$ \\
\hline CDD & 1279 & 1533 & 1509 & $20 \%$ & $2 \%$ \\
\hline
\end{tabular}




\subsection{Modeled air change rates and HVAC system runtimes in the baseline year (2012)}

Modeled annual average, minimum, and maximum hour air change rates due to infiltration, natural ventilation, and both infiltration and natural ventilation combined, as well as HVAC runtime fractions, from the 4,123 modeled homes in the year 2012 are shown in Table S20. Modeled air change rate results indicate that older homes had higher annual average hourly infiltration rates than newer homes, as expected. The average total air change rate for the modeled homes ranged from $0.24 \mathrm{~h}^{-1}$ for homes built after 2009 to 0.52 $\mathrm{h}^{-1}$ for homes built before 1950; this range is consistent with field measurements of new and existing homes in the literature ${ }^{8,64,65}$. Annual average natural ventilation rates were similar for the different home vintages, ranging from a minimum of $0.09 \mathrm{~h}^{-1}$ for homes built after 2009 and the maximum value of $0.14 \mathrm{~h}^{-1}$ for homes built before 1950 .

Modeled annual average hourly HVAC runtimes were similar for the different vintages, albeit with slightly lower values for newer homes compared to older homes. The average across all vintages was $\sim 18 \%$, which is similar to the median of $18 \%$ reported from a study of smart thermostats across North America ${ }^{66}$ and similar to a typical range of $\sim 20-25 \%$ reported in a limited number of studies on residences in the U.S. ${ }^{67,68}$.

Table S20. Minimum, maximum and annual averages ( \pm standard deviations) of the hourly average air change rates and HVAC runtime fractions in the baseline year (2012)

\begin{tabular}{|c|c|c|c|c|c|c|}
\hline \multicolumn{2}{|c|}{ Year of construction } & $<1950$ & 1950-1969 & 1970-1989 & 1990-2009 & 2010-2015 \\
\hline \multirow{3}{*}{$\begin{array}{l}\text { Infiltration, } \\
h^{-1}\end{array}$} & Min & 0.11 & 0.10 & 0.09 & 0.07 & 0.07 \\
\hline & Mean (SD) & $0.38( \pm 0.12)$ & $0.34( \pm 0.11)$ & $0.30( \pm 0.09)$ & $0.21( \pm 0.06)$ & $0.15( \pm 0.05)$ \\
\hline & Max & 0.70 & 0.60 & 0.53 & 0.37 & 0.25 \\
\hline \multirow{3}{*}{$\begin{array}{l}\text { Natural } \\
\text { ventilation, } \\
\mathbf{h}^{-1}\end{array}$} & Min & 0.02 & 0.01 & 0.01 & 0.01 & 0.01 \\
\hline & Mean (SD) & $0.14( \pm 0.1)$ & $0.12( \pm 0.09)$ & $0.12( \pm 0.09)$ & $0.13( \pm 0.09)$ & $0.09( \pm 0.06)$ \\
\hline & $\operatorname{Max}$ & 0.69 & 0.61 & 0.70 & 0.73 & 0.32 \\
\hline \multirow{3}{*}{$\begin{array}{l}\text { Total ACR } \\
\mathbf{h}^{-1}\end{array}$} & Min & 0.14 & 0.11 & 0.11 & 0.08 & 0.08 \\
\hline & Mean (SD) & $0.52( \pm 0.22)$ & $0.46( \pm 0.2)$ & $0.42( \pm 0.18)$ & $0.34( \pm 0.15)$ & $0.24( \pm 0.1)$ \\
\hline & Max & 1.40 & 1.21 & 1.24 & 1.11 & 0.57 \\
\hline \multirow{3}{*}{$\begin{array}{l}\text { HVAC } \\
\text { Runtime, } \\
\%\end{array}$} & Min & 6.0 & 6.8 & 2.9 & 3.2 & 2.5 \\
\hline & Mean (SD) & $19.4( \pm 5.9)$ & $19.6( \pm 7.0)$ & $16.9( \pm 6.4)$ & $16.6( \pm 5.8)$ & $16.5( \pm 6.3)$ \\
\hline & Max & 39.1 & 51.8 & 45.2 & 43.8 & 37.4 \\
\hline
\end{tabular}




\subsection{Modeled indoor pollutant concentrations in the baseline year (2012)}

IAQ model results for the modeled pollutants in the baseline year (2012) are shown in Figure S10, along with a comparison to data from the existing literature on residential pollutant concentrations, indoor/outdoor ratios, and infiltration factors (taken directly from the review conducted in ${ }^{1}$ ). Results show that the results from the baseline year model are well within the typical magnitudes and ranges of indoor concentrations, indoor/outdoor concentration ratios, and infiltration factors as those reported in large residential field studies.
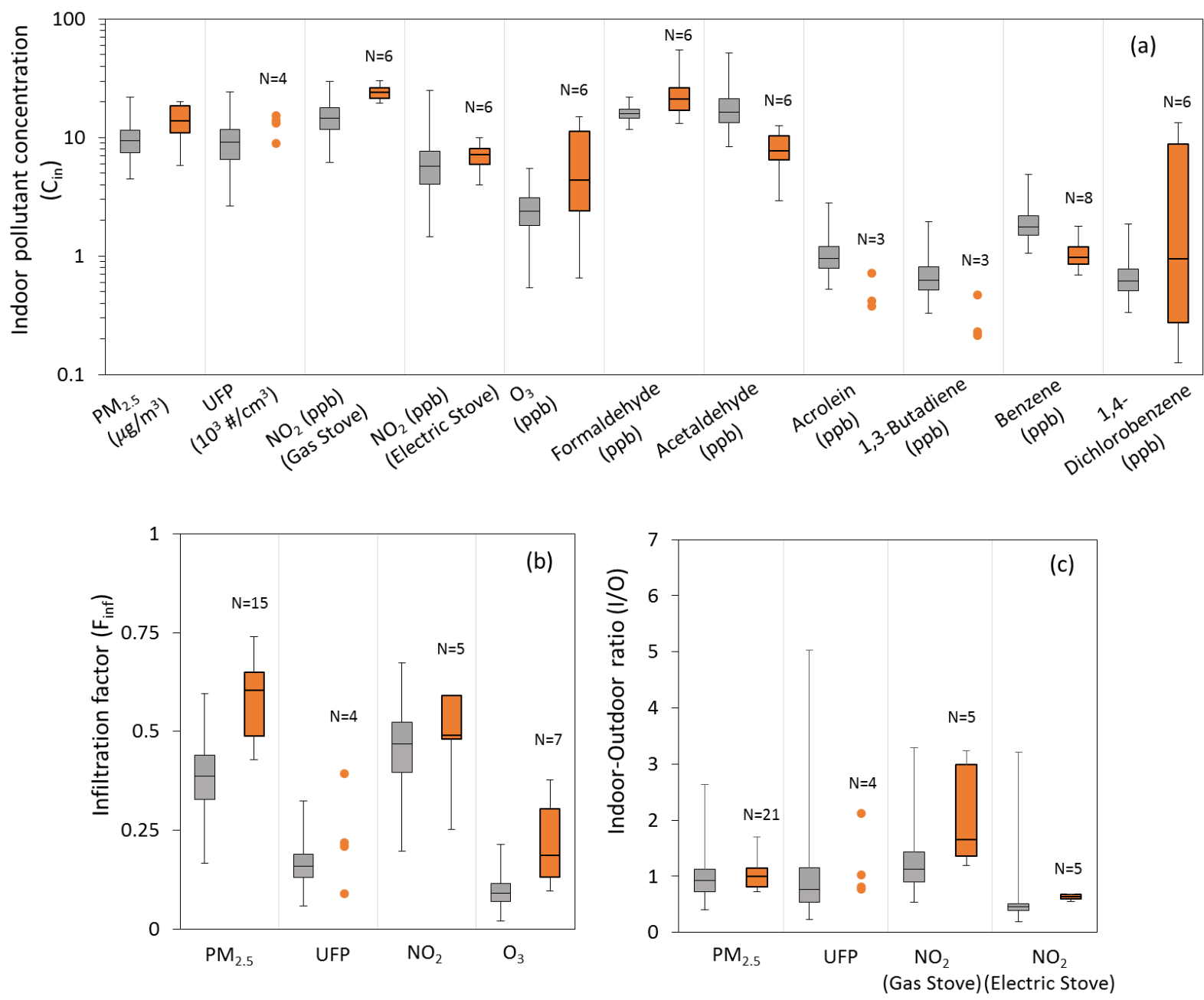

Model Results

Literature

Figure S10. Distributions of model results of annual averages of (a) indoor concentrations of all modeled pollutants (on a log scale), (b) infiltration factors $\left(\mathrm{F}_{\text {inf }}\right)$ for $\mathrm{PM}_{2.5}, \mathrm{UFP}, \mathrm{NO}_{2}$, and $\mathrm{O}_{3}$, and (c) I/O ratios for $\mathrm{PM}_{2.5}$, UFP, and $\mathrm{NO}_{2}$ (split by homes with gas and electric stoves) for the 4,123 model homes in the baseline year (2012) compared to values reported in an extensive literature review for each parameter from ${ }^{1}$. Bars represent the median; boxes represent the $25^{\text {th }}$ and $75^{\text {th }}$ percentiles; and whiskers represent the minimum and maximum ranges. 


\subsection{Modeled DALYs lost due to chronic exposure to residential indoor air pollutants in the baseline year (2012)}

Figure S11 shows the estimated number of DALYs lost due to exposure to all pollutants in the baseline year (2012) made using the modeled population weighted annual average indoor concentrations. Estimates of DALYs lost for criteria pollutants (i.e., $\mathrm{PM}_{2.5}, \mathrm{O}_{3}$, and $\mathrm{NO}_{2}$ ) and aldehydes and VOCs were made using the IND approach and ID approaches in Logue et al. (2012) ${ }^{59}$, respectively. The central estimate of the total DALY burden of chronic pollutant exposures in U.S. residences was approximately 189 DALYs lost per 100,000 persons per year, driven largely by the combined effects associated with exposure to $\mathrm{PM}_{2.5}$ and acrolein.
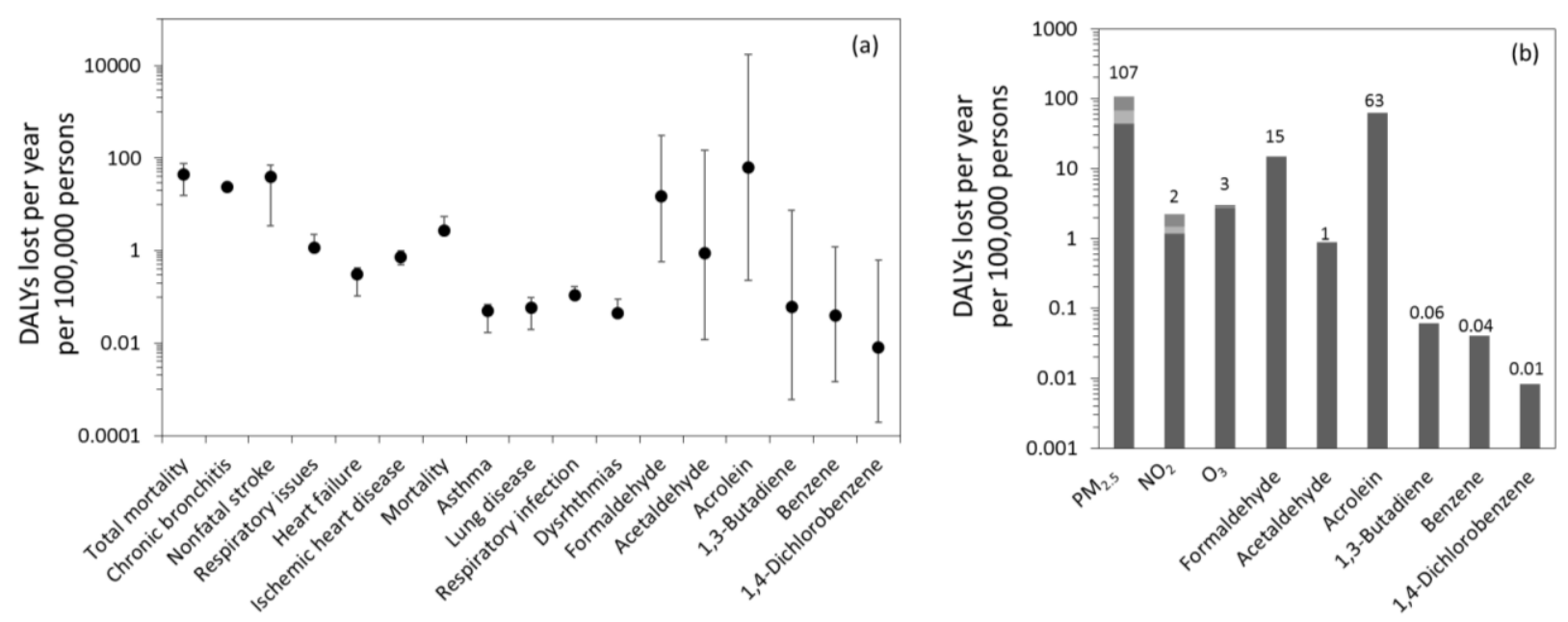

Figure S11. Estimates of annual DALYs lost per 100,000 persons in the baseline year (2012) using the IND and ID approaches from Logue et al. (2012) ${ }^{59}$. The dots in (a) indicate the central estimate of the DALYs lost and the whiskers show the $95 \%$ CI bounds. In (b) the light gray shades for PM PM, $_{2.5}$ $\mathrm{NO}_{2}$, and $\mathrm{O}_{3}$ show the various contributions to total DALYs lost from (a). 


\section{Future years model results $(2050 \mathrm{~s})$}

5.1 Modeled annual space conditioning energy consumption: 2010s vs. 2050s

Figure S12 shows detailed estimated energy use for heating and cooling across the U.S. residential building stock on (a) a site energy basis and (b) a source energy basis for future years (2050s) compared to the baseline year (2012, representing 2010s), taking into consideration changes in the building stock, population movements, and ambient weather and pollutant concentrations that are likely to occur from $\sim 2015$ through the $\sim 2050$ s.

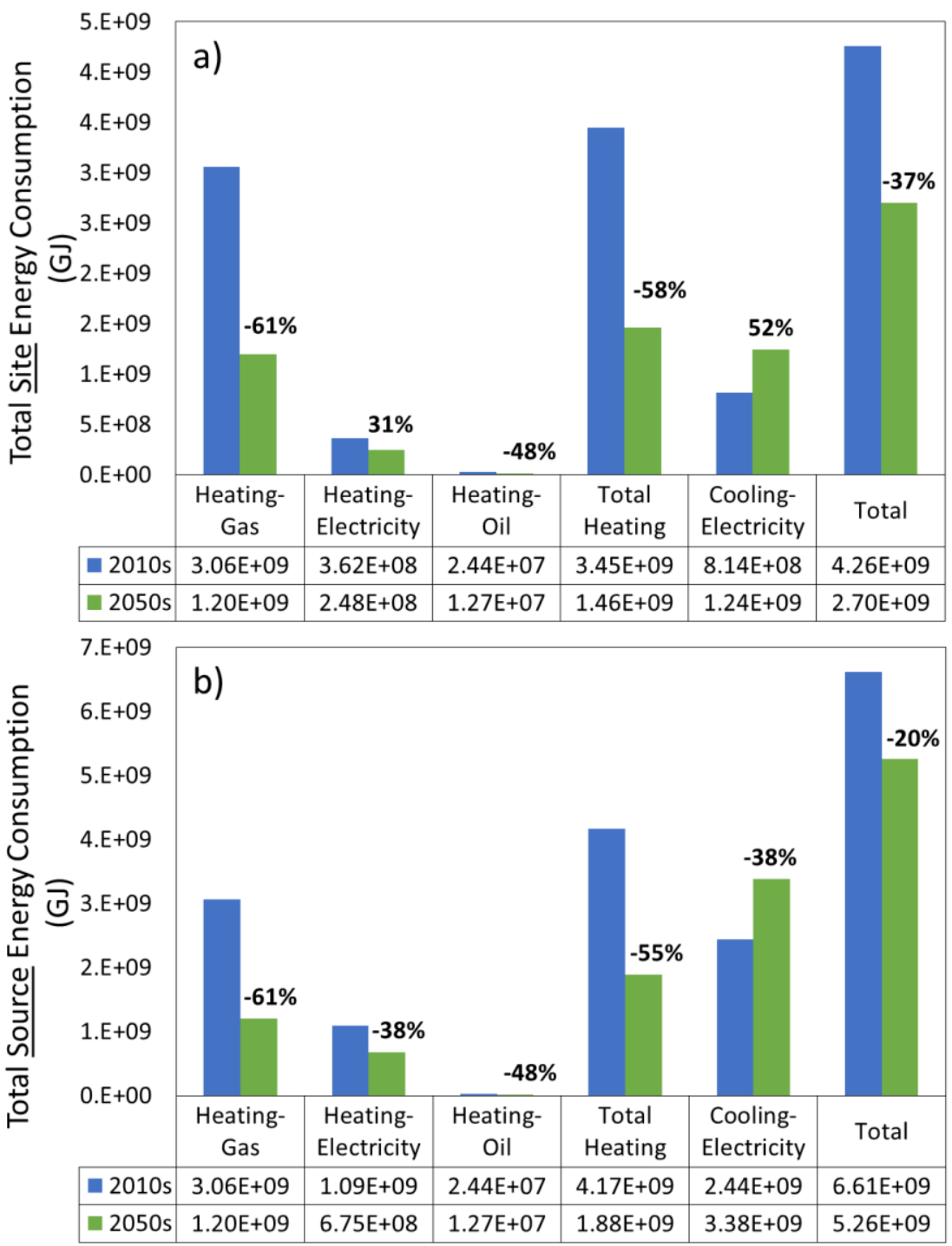

Figure S12. Comparison of total annual residential space conditioning site (a) and source (b) energy consumption for $2010 \mathrm{~s}$ vs. $2050 \mathrm{~s}$ 
5.2 Modeled annual space conditioning energy consumption of the 2012 U.S. housing stock with 2012 and 2050s weather data (isolating climate impacts)

To isolate the impacts of only changing meteorological conditions on building energy use (i.e., climate change acting in the absence of underlying changes to the housing stock and population movements), we applied only the baseline (2012) housing stock model with both the 2012 and 2050s weather data separately (Figure S13). Holding the 2012 housing stock constant and ignoring expected changes to population movements and housing characteristics, we estimate that the total site energy consumption of the U.S. housing stock would decrease by $\sim 20 \%$ in 2050 s compared to 2012 , driven by a $\sim 36 \%$ decrease in heating energy use and a $\sim 45 \%$ increase in cooling energy use.

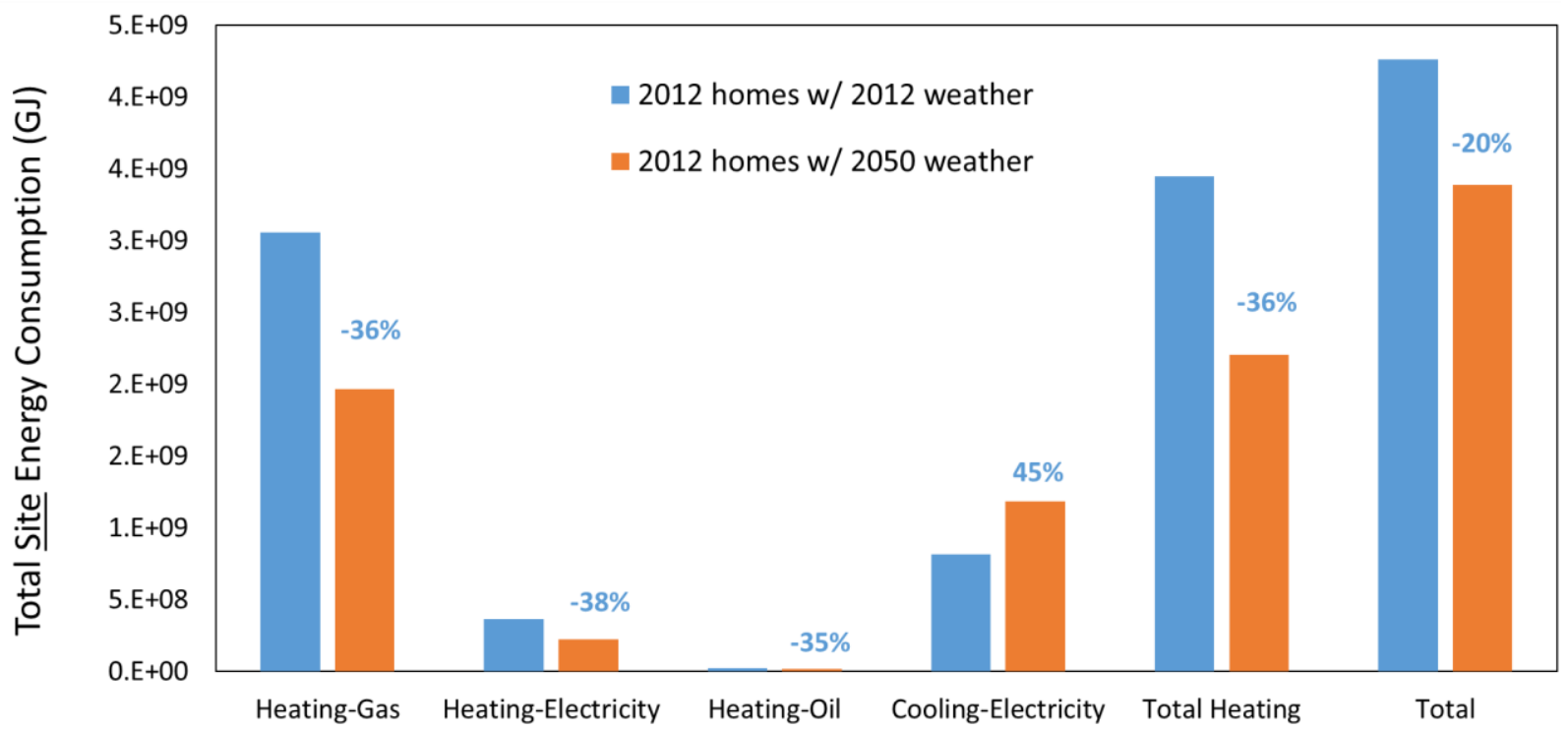

Figure S13. Predicted impacts on climate change alone on site energy use for space conditioning across the 2012 U.S. housing stock using only 2012 and 2050 weather data

To provide some context to these model results, Table S21 shows the number of heating degree days (HDD) and cooling degree days (CDD) for each of the 19 cities, as well as the dwelling-weighted average HDD and CDD, for the 2012 and 2050s simulation years. Overall, the weather files used based on RCP 8.5 show a decrease in the number of HDD and an increase in the number of CDD by 2050s compared to the 2012 model year, with a few exceptions. The net effects yield a $\sim 31 \%$ decrease in dwelling-weighted average HDD and a $\sim 51 \%$ increase in dwelling-weighted average CDD in the 2050s scenario compared to the 2010s scenario. 
Table S21. Heating degree days (HDD) and cooling degree days (CDD) for the 19 model cities for the 2010s and 2050s model scenarios

\begin{tabular}{|c|c|c|c|c|}
\hline \multirow{2}{*}{ Location } & \multicolumn{2}{|c|}{ HDD $\left({ }^{\circ} \mathbf{C}\right.$-days $)$} & \multicolumn{2}{c|}{ CDD $\left({ }^{\circ} \mathbf{C}\right.$-days $)$} \\
\cline { 2 - 5 } & $\mathbf{2 0 1 0 s}$ & $\mathbf{2 0 5 0 s}$ & $\mathbf{2 0 1 0 s}$ & $\mathbf{2 0 5 0 s}$ \\
\hline Atlanta & 1180 & 1316 & 1248 & 1740 \\
\hline Birmingham & 1187 & 1176 & 1324 & 1881 \\
\hline Boston & 2715 & 2282 & 519 & 1308 \\
\hline Buffalo & 3115 & 3199 & 564 & 720 \\
\hline Chicago & 2833 & 1553 & 848 & 622 \\
\hline Cincinnati & 2452 & 2161 & 845 & 1500 \\
\hline Corpus Christi & 338 & 366 & 2484 & 2296 \\
\hline Dallas & 1012 & 1151 & 1949 & 2027 \\
\hline Denver & 2990 & 2733 & 865 & 1088 \\
\hline Los Angeles & 810 & 229 & 409 & 2051 \\
\hline Miami & 118 & 17 & 2370 & 2923 \\
\hline Minneapolis & 3489 & 3048 & 719 & 1220 \\
\hline Nashville & 1658 & 1593 & 1205 & 1758 \\
\hline New York & 2295 & 717 & 687 & 1263 \\
\hline Phoenix & 511 & 356 & 3021 & 3084 \\
\hline Seattle & 2637 & 1723 & 178 & 499 \\
\hline St Louis & 2021 & 1949 & 1343 & 1818 \\
\hline Washington & 2228 & 355 & 888 & 1518 \\
\hline Worcester & 3198 & 2820 & 421 & 810 \\
\hline Dwelling-weighted & $\mathbf{1 8 4 3}$ & $\mathbf{1 2 6 9}$ & $\mathbf{1 1 3 9}$ & $\mathbf{1 7 2 4}$ \\
\hline average & & & & \\
\hline
\end{tabular}

\subsection{Modeled air change rates and HVAC system runtimes in mid-century (2050s)}

Modeled annual average, minimum, and maximum hour air change rates due to infiltration, natural ventilation, and both infiltration and natural ventilation combined, as well as HVAC runtime fractions, from the 8,246 modeled homes in the 2050s are shown in Table S22. Similar to the 2012 model set, older homes are estimated to have higher annual average air change rates than new homes, as expected. The average total air change rate for the modeled homes ranged from $0.14 \mathrm{~h}^{-1}$ for homes built after 2030 to $0.47 \mathrm{~h}^{-1}$ for homes built before 1950. The annual average total air change rate across all vintages in $2050 \mathrm{~s}$ is $0.27 \mathrm{~h}^{-1}$, which is $\sim 31 \%$ less than the 2012 model set. Modeled annual average hourly HVAC runtimes across the model set (not accounting for population-weighting) were similar across different vintages, with a mean of $\sim 22 \%$, which was slightly higher than the mean of $\sim 18 \%$ from the 2012 model set. 
Table S22. Minimum, maximum and annual averages ( \pm standard deviations) of the predicted hourly average air change rates and HVAC runtime fractions in 2050s

\begin{tabular}{|c|c|c|c|c|c|c|c|}
\hline \multicolumn{2}{|c|}{ Year of construction } & $<1950$ & 1950-1969 & 1970-1989 & 1990-2009 & 2010-2029 & $2030-2050$ \\
\hline \multirow{3}{*}{$\begin{array}{l}\text { Infiltration, } \\
h^{-1}\end{array}$} & Min & 0.08 & 0.07 & 0.08 & 0.06 & 0.06 & 0.04 \\
\hline & $\begin{array}{l}\text { Mean } \\
\text { (SD) }\end{array}$ & $\begin{array}{c}0.37 \\
( \pm 0.18)\end{array}$ & $\begin{array}{c}0.34 \\
( \pm 0.17)\end{array}$ & $\begin{array}{c}0.3 \\
( \pm 0.13)\end{array}$ & $\begin{array}{c}0.21 \\
( \pm 0.08)\end{array}$ & $\begin{array}{c}0.12 \\
( \pm 0.04)\end{array}$ & $\begin{array}{c}0.07 \\
( \pm 0.02)\end{array}$ \\
\hline & Max & 1.15 & 0.99 & 0.85 & 0.54 & 0.22 & 0.14 \\
\hline \multirow{3}{*}{$\begin{array}{l}\text { Natural } \\
\text { ventilation, } \\
\mathbf{h}^{-1}\end{array}$} & Min & 0.001 & 0.002 & 0.002 & 0.002 & 0.002 & 0.002 \\
\hline & $\begin{array}{l}\text { Mean } \\
\text { (SD) }\end{array}$ & $\begin{array}{c}0.1 \\
( \pm 0.1)\end{array}$ & $\begin{array}{c}0.09 \\
( \pm 0.1)\end{array}$ & $\begin{array}{c}0.09 \\
( \pm 0.1)\end{array}$ & $\begin{array}{c}0.09 \\
( \pm 0.09)\end{array}$ & $\begin{array}{c}0.07 \\
( \pm 0.06)\end{array}$ & $\begin{array}{c}0.07 \\
( \pm 0.06)\end{array}$ \\
\hline & Max & 1.05 & 0.94 & 0.97 & 0.92 & 0.40 & 0.39 \\
\hline \multirow{3}{*}{$\begin{array}{l}\text { Total ACR } \\
\mathbf{h}^{-1}\end{array}$} & Min & 0.08 & 0.07 & 0.08 & 0.06 & 0.06 & 0.04 \\
\hline & $\begin{array}{c}\text { Mean } \\
\text { (SD) }\end{array}$ & $\begin{array}{c}0.47 \\
( \pm 0.28)\end{array}$ & $\begin{array}{c}0.43 \\
( \pm 0.28)\end{array}$ & $\begin{array}{c}0.39 \\
( \pm 0.24)\end{array}$ & $\begin{array}{c}0.31 \\
( \pm 0.17)\end{array}$ & $\begin{array}{c}0.19 \\
( \pm 0.1)\end{array}$ & $\begin{array}{c}0.14 \\
( \pm 0.09)\end{array}$ \\
\hline & Max & 2.19 & 1.93 & 1.82 & 1.46 & 0.62 & 0.53 \\
\hline \multirow{3}{*}{$\begin{array}{l}\text { HVAC } \\
\text { Runtime, } \\
\%\end{array}$} & Min & 7.9 & 6.5 & 4.7 & 5.8 & 5.4 & 5.3 \\
\hline & $\begin{array}{c}\text { Mean } \\
\text { (SD) }\end{array}$ & $\begin{array}{c}21.3 \\
( \pm 7.1)\end{array}$ & $\begin{array}{c}22.8 \\
( \pm 8.1)\end{array}$ & $\begin{array}{c}21.4 \\
( \pm 8.4)\end{array}$ & $\begin{array}{c}21.7 \\
( \pm 7.0)\end{array}$ & $\begin{array}{c}21.6 \\
( \pm 8.0)\end{array}$ & $\begin{array}{c}22.7 \\
( \pm 9.5)\end{array}$ \\
\hline & Max & 44.6 & 54.9 & 62.7 & 56.8 & 63.7 & 62.2 \\
\hline
\end{tabular}

\subsection{Modeled indoor pollutant concentrations in mid-century (2050s)}

Figure S14 shows resulting estimates of the population-weighted average indoor concentrations of $\mathrm{PM}_{2.5}$, UFPs, $\mathrm{NO}_{2}$, and $\mathrm{O}_{3}$ for the six modeled home vintages in the 2050s model set, separated by indoor and ambient contributions. Figure S15 shows resulting estimates of the population-weighted average indoor concentrations of several modeled VOCs and aldehydes for the six modeled home vintages in the 2050s model set.
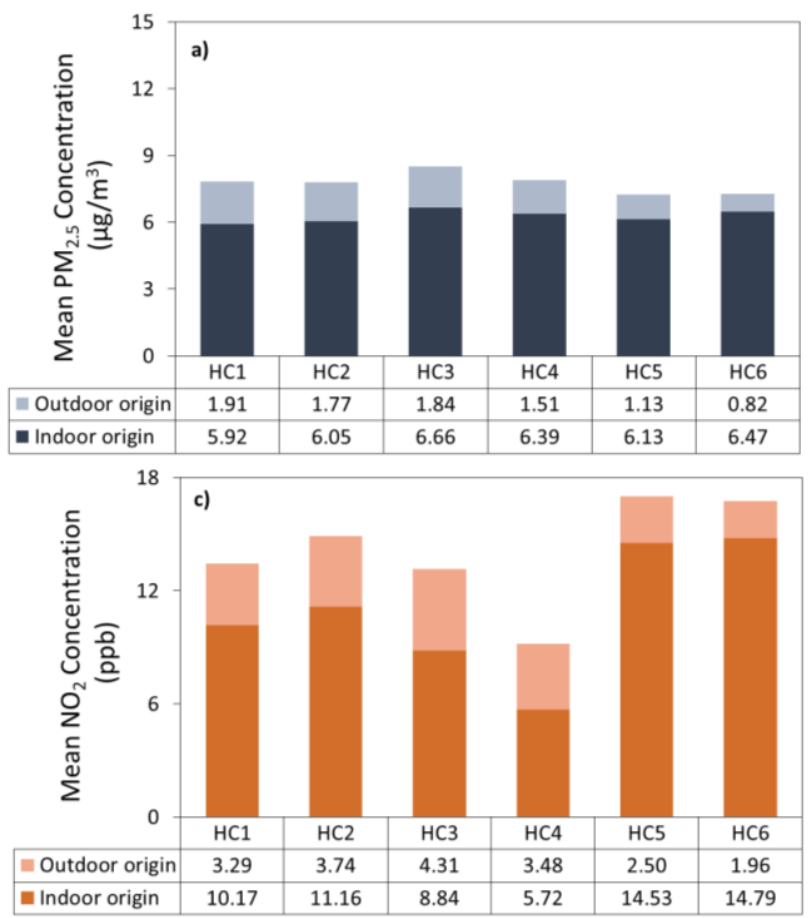
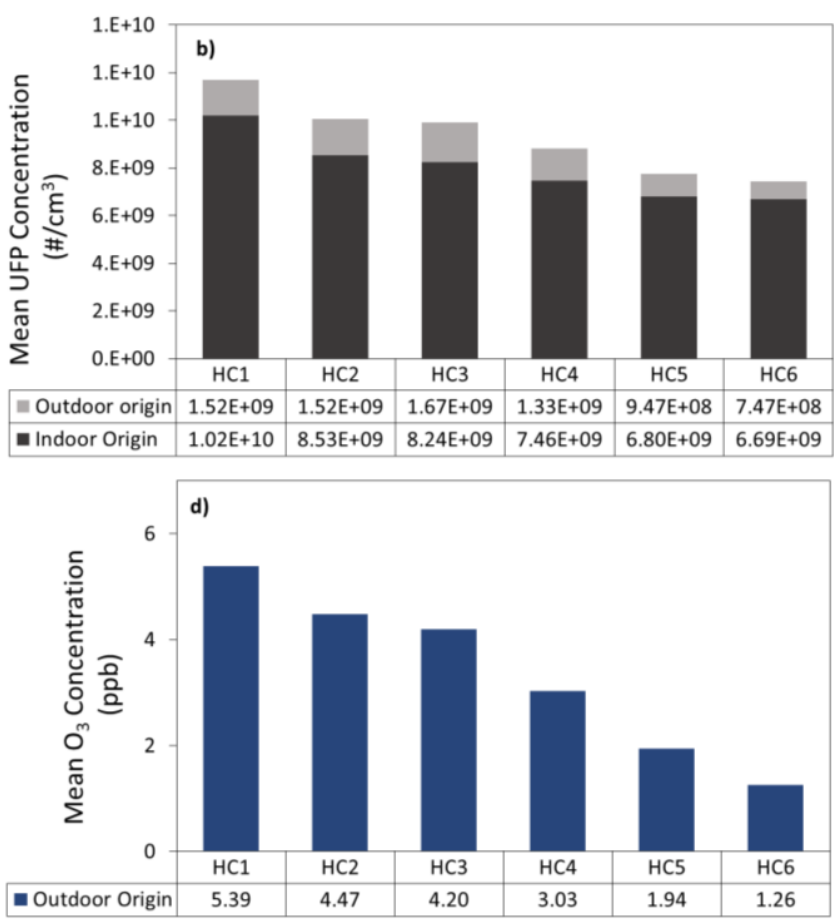

Figure S14. Population-weighted average indoor concentrations of $\mathrm{PM}_{2.5}, \mathrm{UFPs}, \mathrm{NO}_{2}$, and $\mathrm{O}_{3}$ for the six modeled home vintages in the 2050 s model set ("HC1" through "HC6"), separated by indoor and ambient contributions 


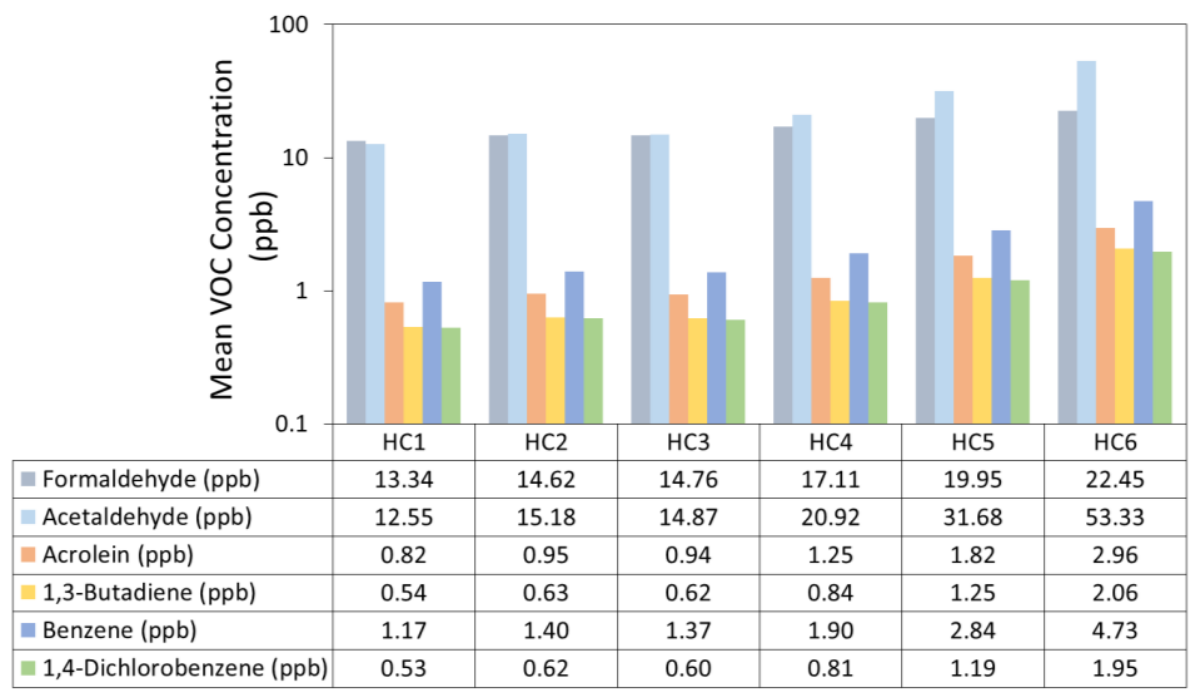

Figure S15. Population-weighted average indoor concentrations of several modeled VOCs and aldehydes for the six modeled home vintages in the 2050s model set ("HC1" through "HC6")

To explore the effects of different factors that contribute to the resulting 2050s IAQ model set, Figure S16 shows four scenarios of population-weighted annual average indoor pollutant concentration resulting from the model applied to the 2010s and 2050s scenarios:

(1) Baseline year (2012 representing the 2010s), with the housing stock model, meteorological conditions, outdoor pollutant concentrations, and population distributions each based on 2010s model inputs;

(2) 2050s-Alt \#1, with the 2010s housing stock model, 2010s population distribution, and 2010s outdoor pollutant concentrations, but with 2050s meteorological conditions applied (to infer the influence of future climate alone);

(3) 2050s-Alt \#2, with the 2010s housing stock model and 2010s population distribution applied with 2050s outdoor pollutant concentrations and 2050s meteorological conditions (to infer the influence of future climate and future ambient air quality); and

(4) The full 2050s model, with the housing stock model, population distribution, meteorological conditions, and outdoor pollutant concentrations all from the $2050 \mathrm{~s}$.

First, comparing the 2050s-Alt \#1 model results to the 2010s model results provides some inference into the impacts of future meteorological conditions alone, holding all other factors constant. In this comparison, the annual average indoor concentrations of pollutants of indoor origin are predicted to decrease by $\sim 6$ $14 \%$, suggesting that future meteorological conditions alone (applied to the current housing stock and population distribution) would slightly increase air change rates and lead to greater dilution of pollutants of indoor origin. Conversely, the annual average indoor concentrations of pollutants of outdoor origin are predicted to increase by a similar magnitude, as greater air change rates with the outdoors introduces greater amounts of ambient air pollutants. The net impact of these two competing effects results in slight increases in the annual average indoor concentrations of $\mathrm{O}_{3}$ and $\mathrm{NO}_{2}$ and slight decreases in $\mathrm{PM}_{2.5}$ and UFPs. 


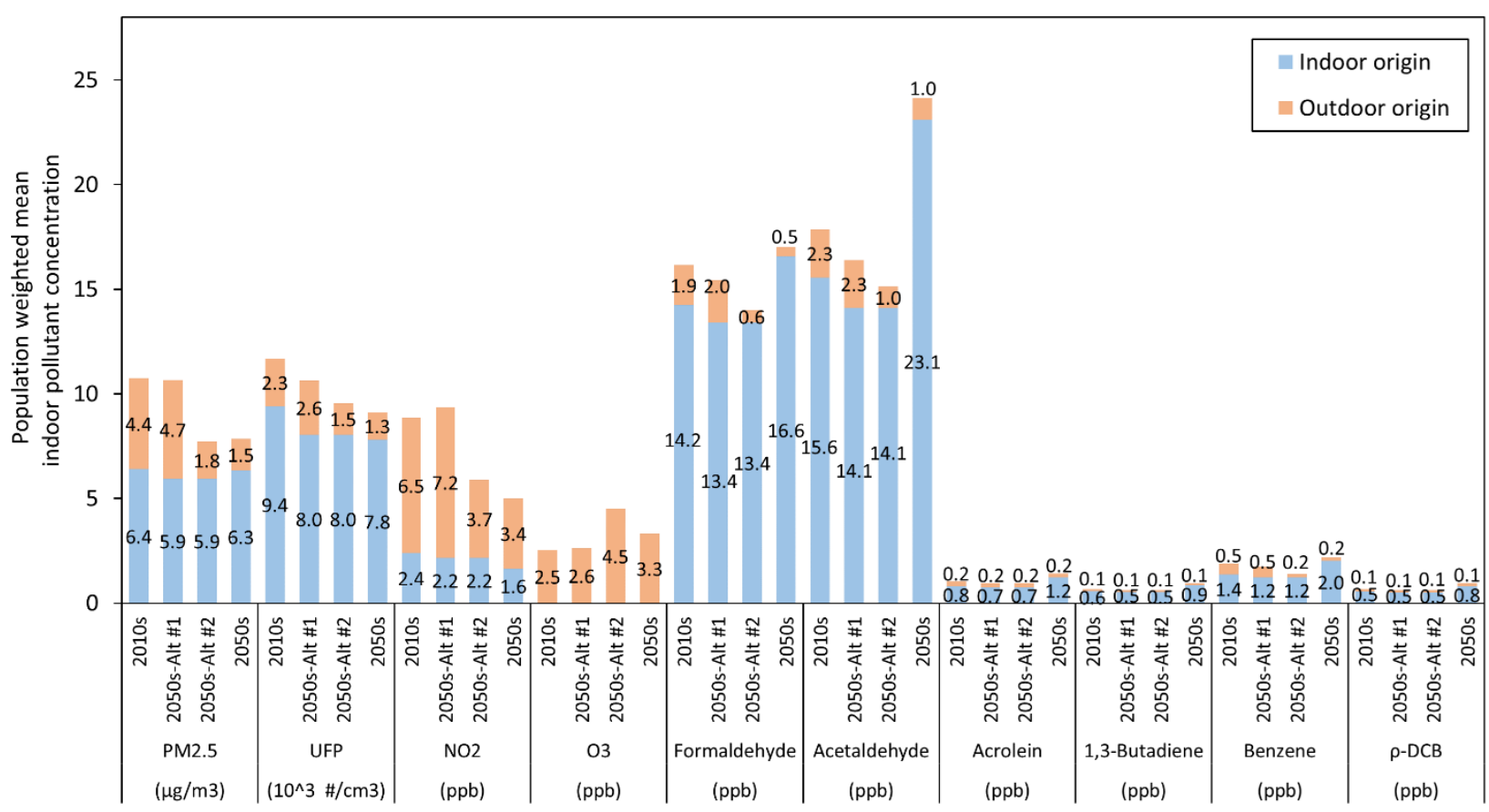

Figure S16. Population-weighted annual average indoor pollutant concentrations under four model scenarios: 2010s, 2050s-Alt \#1, 2050s Alt \#2, and 2050s. "2050s-Alt \#1" refers to 2010s housing stock and population distribution with outdoor pollutant concentrations from the $2010 \mathrm{~s}$ but with weather data from the 2050s. "2050s-Alt \#2" refers to the 2010s housing stock and population distribution with outdoor pollutant concentrations and weather data both from the 2050s.

Second, comparing the 2050s-Alt \#2 model results to the 2010s model results provides some inference into the impacts of both future meteorological conditions and future outdoor air quality, again holding the housing stock and population distribution constant. Note that because both the 2050s-Alt \#1 and 2050s Alt \#2 scenarios are modeled with the baseline 2010s housing stock and population distribution and 2050s weather files, the resulting indoor concentrations of pollutants of indoor origin experience the same magnitudes of changes. In this comparison between 2050s-Alt \#2 and 2010s, there is a large decrease (ranging $~ 34-70 \%$ ) in predicted annual average indoor concentrations of most pollutants of outdoor origin, except for $\mathrm{O}_{3}$, which increases by $\sim 77 \%$. The net effects demonstrate that the combination of predicted changes to both future weather and outdoor air quality conditions, while holding the 2010s housing stock and population distribution constant, would lead to a decrease in the annual average indoor concentrations of all pollutants (including both indoor and outdoor origin) of between 13 to $34 \%$, except for $\mathrm{O}_{3}$, which would increase due to expected increases in ambient concentrations.

Finally, the full 2050s model results demonstrate the impacts of a changing housing stock and population distribution in addition to changing climate and ambient air quality conditions. Annual average indoor concentrations of UFPs, $\mathrm{NO}_{2}$, and $\mathrm{O}_{3}$ are all predicted to decrease compared to 2050s-Alt \#2 (by 4\%, $\sim 15 \%$, and $\sim 27 \%$, respectively), while $\mathrm{PM}_{2.5}$ is predicted to increase $\sim 2 \%$ and VOCs and aldehydes are predicted to increase by $\sim 22-60 \%$. These comparisons demonstrate the potential magnitude of the competing effects that these changing factors - housing stock, population movements, climate conditions, and ambient air quality - might have on future population exposures to pollutants of both indoor and outdoor origin. 


\subsection{Modeled DALYs lost due to chronic exposure to residential indoor air pollutants in 2050s}

Figure S17 shows the estimated number of DALYs lost due to exposure to all pollutants made in the 2050s scenario using the modeled population-weighted annual average indoor concentrations. The central estimate of the total DALY burden of chronic pollutant exposures in U.S. residences was approximately 189 DALYs lost per 100,000 persons per year, still driven largely by the combined effects associated with exposure to $\mathrm{PM}_{2.5}$ and acrolein, but with varying contributions among the different modeled pollutants.
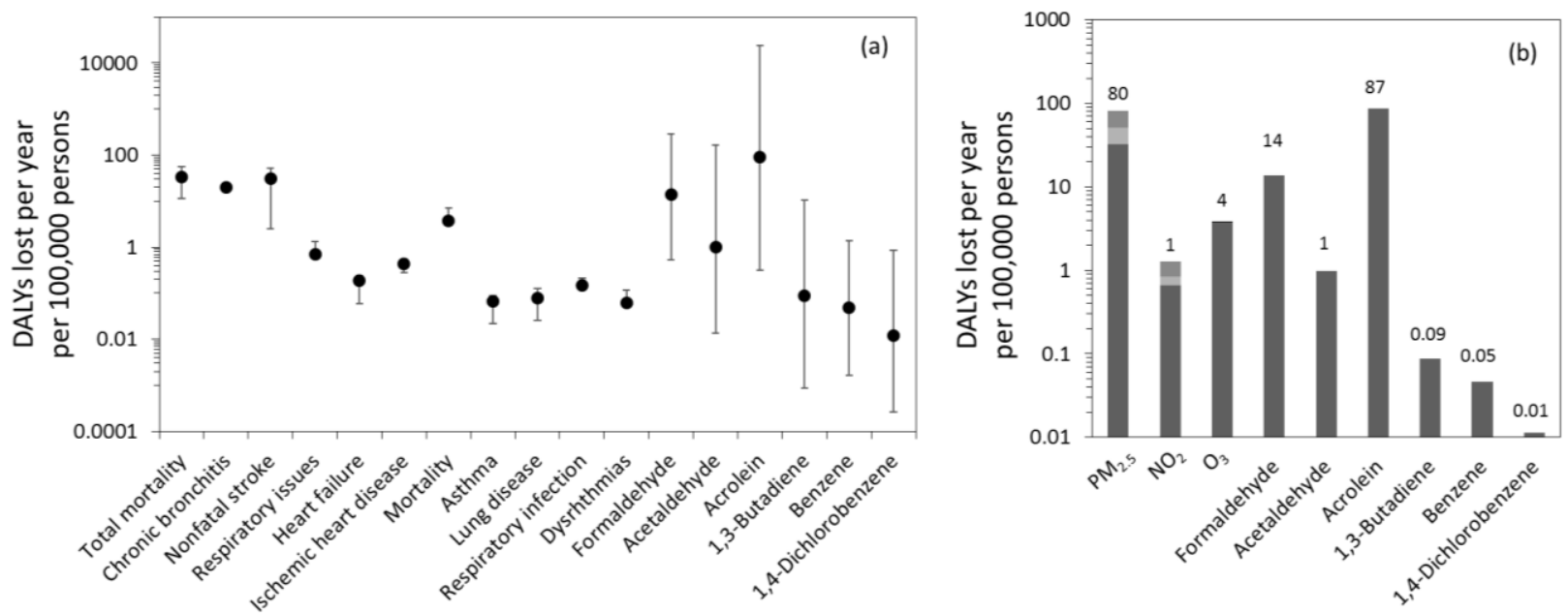

Figure S17. Estimates of annual DALYs lost per 100,000 persons in 2050s using the IND and ID approaches from Logue et al. (2012) ${ }^{59}$. The dots in (a) indicate the central estimate of the DALYs lost and the whiskers show the $95 \%$ CI bounds. In (b) the light gray shades for $\mathrm{PM}_{2.5}, \mathrm{NO}_{2}$, and $\mathrm{O}_{3}$ show the various contributions to total DALYs lost from (a). 


\section{SI References}

(1) Fazli, T.; Stephens, B. Development of a Nationally Representative Set of Combined Building Energy and Indoor Air Quality Models for U.S. Residences. Building and Environment 2018, 136, 198-212. https://doi.org/10.1016/j.buildenv.2018.03.047.

(2) Persily, A. K.; Musser, A.; Leber, D. A Collection of Homes to Represent the U.S. Housing Stock; NISTIR 7330; National Institute of Standards and Technology (NIST): Gaithersburg, MD, 2006.

(3) EIA, U. S. RESIDENTIAL ENERGY CONSUMPTION SURVEY (RECS) https://www.eia.gov/consumption/residential/about.php.

(4) EIA, U. S. 2015 RECS Household Characteristics Technical Documentation Summary. U.S. Department of Energy 2018.

(5) U.S Energy Information Administration, Residential Energy Consumption Survey (RECS) http://www.eia.gov/ (accessed Jan 1, 2016).

(6) U.S. Census Bureau. Characteristics of New Housing https://www.census.gov/construction/chars/ (accessed Mar 1, 2020).

(7) Software Help | BEopt https://beopt.nrel.gov/softwareHelp (accessed Jan 16, 2017).

(8) Persily, A.; Musser, A.; Emmerich, S. J. Modeled Infiltration Rate Distributions for U.S. Housing. Indoor Air 2010, 20 (6), 473-485. https://doi.org/10.1111/j.1600-0668.2010.00669.x.

(9) US EPA. Download Detailed AQS Data. Technology Transfer Network (TTN) Air Quality System (AQS), 2013.

(10) White Box Technologies. Weather Data for Energy Calculations: Historical Data. White Box Technologies Weather Data, 2015.

(11) U.S. Census Bureau, Population DivisionU.S. Census Bureau. Annual Estimates of the Resident Population: April 1, 2010 to July 1, 2017; 2017.

(12) LBL. Envelope Leakage. Residential Diagnostics Database, 2012.

(13) ASHRAE. ASHRAE Handbook of Fundamentals. 2009.

(14) Huang, J.; Ritschard, R.; Bull, J.; Byrne, S.; Turiel, I.; Wilson, D.; Hsui, C.; Foley, D. Methodology and Assumptions for Evaluating Heating and Cooling Energy Requirements in New Single-Family Residential Buildigs; LBL-19128; Lawrence Berkeley National Laboratory, 1987.

(15) Huang, J.; Hanford, J.; Yang, F. Residential Heating and Cooling Loads Component Analysis; LBNL-44636; Lawrence Berkeley National Laboratory, 1999.

(16) IECC. International Energy Conservation Code. 2000.

(17) BCAP. Building Codes Assistance Project http://bcapcodes.org/code-status/slideshow/.

(18) LBNL. Heating and Cooling Equipment Efficiencies - Legacy System - Home Energy Saver \& Score: Engineering Documentation http://hes-documentation.lbl.gov/calculationmethodology/calculation-of-energy-consumption/heating-and-cooling-calculation/heating-andcooling-equipment/heating-equipment-efficiency (accessed Mar 5, 2019).

(19) Navigant Consulting, Inc. EIA-Technology Forecast Updates-Residential and Commercial Building Technologies-Advanced Case; 2018.

(20) Smith, S. K.; Tayman, J.; Swanson, D. A. State and Local Population Projections: Methodology and Analysis; Springer Science \& Business Media, 2006.

(21) Polymenopoulos, A. D.; Long, G. Estimation and Evaluation Methods for Population Growth Models with Spatial Diffusion: Dynamics of Mountain Pine Beetle. Ecological Modelling 1990, 51 (1), 97-121. https://doi.org/10.1016/0304-3800(90)90060-T.

(22) van Imhoff, E.; Post, W. Microsimulation Methods for Population Projection. Population: An English Selection 1998, 10 (1), 97-138.

(23) Passel, J. S.; Cohn, D. U.S. Population Projections: 2005-2050. 2008, 55.

(24) ProximityOne. http://proximityone.com.

(25) U.S. Census Bureau. Projected Population Size and Births, Deaths, and Migration: Main Projections Series for the United States, 2017-2060; Population Division: Washington, DC, 2018. 
(26) JCHS. JCHS Tabulations of the Department of Housing and Urban Development (HUD), 1995 2015 American Housing Surveys; 2017.

(27) Chan, W. R.; Sherman, M. H. Improving Building Envelope and Duct Airtightness of US Dwellings - The Current State of Energy Retrofits; Rockville, MD, 2013.

(28) Berry, L. Patterns of Impact in the Weatherization Assistance Program: A Closer Look. Oak Ridge National Laboratory 1997.

(29) Judkoff, R.; Hancock, E.; Franconi, E.; Hanger, R.; Weiger, J. Mobile Home Weatherization Measures: A Study of Their Effectiveness. Solar Energy Research Institute 1988.

(30) AEO. Residential Demand Module of the National Energy Modeling System: Model Documentation 2018; U.S. Energy Information Administration: Washington, DC, 2018.

(31) Athalye, R. A.; Sivaraman, D.; Elliott, D. B.; Liu, B.; Bartlett, R. Impacts of Model Building Energy Codes; PNNL--25611-Rev1, 1334003; 2016. https://doi.org/10.2172/1334003.

(32) Skamarock, W. C.; Klemp, J. B. A Time-Split Nonhydrostatic Atmospheric Model for Weather Research and Forecasting Applications. Journal of Computational Physics 2008, 227 (7), 34653485. https://doi.org/10.1016/j.jcp.2007.01.037.

(33) Gao, Y.; Fu, J. S.; Drake, J. B.; Liu, Y.; Lamarque, J.-F. Projected Changes of Extreme Weather Events in the Eastern United States Based on a High Resolution Climate Modeling System. Environ. Res. Lett. 2012, 7 (4), 044025. https://doi.org/10.1088/1748-9326/7/4/044025.

(34) Troup, L.; Fannon, D. Morphing Climate Data to Simulate Building Energy Consumption. Proceedings of SimBuild 2016, 6 (1).

(35) Azimi, P.; Zhao, D.; Stephens, B. Modeling the Impact of Residential HVAC Filtration on Indoor Particles of Outdoor Origin (RP-1691). Science and Technology for the Built Environment 2016, 22 (4), 431-462. https://doi.org/10.1080/23744731.2016.1163239.

(36) Weisel, C. P.; Zhang, J. (Jim); Turpin, B. J.; Morandi, M. T.; Colome, S.; Stock, T. H.; Spektor, D. M.; Korn, L.; Winer, A.; Alimokhtari, S.; Kwon, J.; Mohan, K.; Harrington, R.; Giovanetti, R.; Cui, W.; Afshar, M.; Maberti, S.; Shendell, D. Relationship of Indoor, Outdoor and Personal Air (RIOPA) Study: Study Design, Methods and Quality Assurance/Control Results. Journal of Exposure Analysis and Environmental Epidemiology 2004, 15, 123-137. https://doi.org/10.1038/sj.jea.7500379.

(37) Sun, J.; Fu, J. S.; Huang, K.; Gao, Y. Estimation of Future PM2.5- and Ozone-Related Mortality over the Continental United States in a Changing Climate: An Application of High-Resolution Dynamical Downscaling Technique. Journal of the Air \& Waste Management Association 2015, 65 (5), 611-623. https://doi.org/10.1080/10962247.2015.1033068.

(38) Tesche, T. W.; Morris, R.; Tonnesen, G.; McNally, D.; Boylan, J.; Brewer, P. CMAQ/CAMx Annual 2002 Performance Evaluation over the Eastern US. Atmospheric Environment 2006, 40 (26), 4906-4919. https://doi.org/10.1016/j.atmosenv.2005.08.046.

(39) Lam, Y. F.; Fu, J. S.; Wu, S.; Mickley, L. J. Impacts of Future Climate Change and Effects of Biogenic Emissions on Surface Ozone and Particulate Matter Concentrations in the United States. Atmospheric Chemistry and Physics 2011, 11 (10), 4789-4806. https://doi.org/10.5194/acp-114789-2011.

(40) Waring, M. S. Secondary Organic Aerosol in Residences: Predicting Its Fraction of Fine Particle Mass and Determinants of Formation Strength. Indoor Air 2014, 24, 376-389. https://doi.org/10.1111/ina.12092.

(41) Plaisance, H.; Blondel, A.; Desauziers, V.; Mocho, P. Evidence of Indoor Sinks for Formaldehyde through the Field Measurements Using Passive Flux Sampler and Mass Balance. Environ Sci Pollut Res 2019, 26 (29), 29679-29686. https://doi.org/10.1007/s11356-019-06057-2.

(42) Weschler, C. J. Changes in Indoor Pollutants since the 1950s. Atmospheric Environment 2009, 43 (1), 153-169. https://doi.org/10.1016/j.atmosenv.2008.09.044.

(43) Thatcher, T. L.; Lunden, M. M.; Revzan, K. L.; Sextro, R. G.; Brown, N. J. A Concentration Rebound Method for Measuring Particle Penetration and Deposition in the Indoor Environment. Aerosol Sci. Technol. 2003, 37 (11), 847-864. https://doi.org/10.1080/02786820300940. 
(44) Long, C. M.; Suh, H. H.; Catalano, P. J.; Koutrakis, P. Using Time- and Size-Resolved Particulate Data to Quantify Indoor Penetration and Deposition Behavior. Environ. Sci. Technol. 2001, 35 (10), 2089-2099. https://doi.org/10.1021/es001477d.

(45) Logue, J. M.; Sherman, M. H.; Lunden, M. M.; Klepeis, N. E.; Williams, R.; Croghan, C.; Singer, B. C. Development and Assessment of a Physics-Based Simulation Model to Investigate Residential PM2.5 Infiltration across the US Housing Stock. Building and Environment 2015, 94, 21-32. https://doi.org/10.1016/j.buildenv.2015.06.032.

(46) Stephens, B.; Siegel, J. A. Penetration of Ambient Submicron Particles into Single-Family Residences and Associations with Building Characteristics. Indoor Air 2012, 22 (6), 501-513. https://doi.org/10.1111/j.1600-0668.2012.00779.x.

(47) Stephens, B.; Gall, E. T.; Siegel, J. A. Measuring the Penetration of Ambient Ozone into Residential Buildings. Environ. Sci. Technol. 2012, 46 (2), 929-936. https://doi.org/10.1021/es2028795.

(48) Fabian, P.; Adamkiewicz, G.; Levy, J. I. Simulating Indoor Concentrations of NO2 and PM2.5 in Multifamily Housing for Use in Health-Based Intervention Modeling: CONTAM Simulation of Indoor NO2 and PM2.5. Indoor Air 2012, 22 (1), 12-23. https://doi.org/10.1111/j.16000668.2011.00742.x.

(49) Kearney, J.; Wallace, L.; MacNeill, M.; Xu, X.; VanRyswyk, K.; You, H.; Kulka, R.; Wheeler, A. J. Residential Indoor and Outdoor Ultrafine Particles in Windsor, Ontario. Atmos. Environ. 2011, 45 (40), 7583-7593. https://doi.org/10.1016/j.atmosenv.2010.11.002.

(50) Lee, K.; Vallarino, J.; Dumyahn, T.; Ozkaynak, H.; Spengler, J. D. Ozone Decay Rates in Residences. J. Air Waste Ma. 1999, 49 (10), 1238-1244.

(51) Noris, F.; Adamkiewicz, G.; Delp, W. W.; Hotchi, T.; Russell, M.; Singer, B. C.; Spears, M.; Vermeer, K.; Fisk, W. J. Indoor Environmental Quality Benefits of Apartment Energy Retrofits. Building and Environment 2013, 68, 170-178. https://doi.org/10.1016/j.buildenv.2013.07.003.

(52) Hecker, R.; Hofacre, K. C. Development of Performance Data for Common Building Air Cleaning Devices; Final Report EPA/600/R-08/013; U.S. Environmental Protection Agency: Office of Research and Development/National Homeland Security Research Center Research Triangle Park, NC, 2008.

(53) Abt, E.; Suh, H. H.; Catalano, P.; Koutrakis, P. Relative Contribution of Outdoor and Indoor Particle Sources to Indoor Concentrations. Environ. Sci. Technol. 2000, 34 (17), 3579-3587. https://doi.org/10.1021/es990348y.

(54) He, C.; Morawska, L.; Hitchins, J.; Gilbert, D. Contribution from Indoor Sources to Particle Number and Mass Concentrations in Residential Houses. Atmospheric Environment 2004, 38 (21), 3405-3415. https://doi.org/10.1016/j.atmosenv.2004.03.027.

(55) Buonanno, G.; Morawska, L.; Stabile, L. Particle Emission Factors during Cooking Activities. Atmospheric Environment 2009, 43 (20), 3235-3242. https://doi.org/10.1016/j.atmosenv.2009.03.044.

(56) Wallace, L.; Ott, W. Personal Exposure to Ultrafine Particles. J Expo Sci Environ Epidemiol 2011, 21 (1), 20-30. https://doi.org/10.1038/jes.2009.59.

(57) Moschandreas, D. J.; Relwani, S. M. Field Measurements of NO2 Gas Range-Top Burner Emission Rates. Environment International 1989, 15 (1), 489-492. https://doi.org/10.1016/01604120(89)90066-4.

(58) Relwani, S. M.; Moschandreas, D. J.; Billick, I. H. Effects of Operational Factors on Pollutant Emission Rates from Residential Gas Appliances. Journal of the Air Pollution Control Association 1986, 36 (11), 1233-1237. https://doi.org/10.1080/00022470.1986.10466170.

(59) Logue, J. M.; Price, P. N.; Sherman, M. H.; Singer, B. C. A Method to Estimate the Chronic Health Impact of Air Pollutants in U.S. Residences. Environmental Health Perspectives 2012, 120 (2), 216-222. https://doi.org/10.1289/ehp.1104035.

(60) Huijbregts, M. A. J.; Rombouts, L. J. A.; Ragas, A. M. J.; van de Meent, D. Human-Toxicological Effect and Damage Factors of Carcinogenic and Noncarcinogenic Chemicals for Life Cycle Impact Assessment. Integr Environ Assess Manag 2005, 1 (3), 181-244. 
(61) US EPA. The Benefits and Costs of the Clean Air Act from 1990 to 2010; Final Report-Rev. A; U.S. Environmental Protection Agency Office of Air and Radiation: Washington, DC, 1999.

(62) Klepeis, N. E.; Nelson, W. C.; Ott, W. R.; Robinson, J. P.; Tsang, A. M.; Switzer, P.; Behar, J. V.; Hern, S. C.; Engelmann, W. H. The National Human Activity Pattern Survey (NHAPS): A Resource for Assessing Exposure to Environmental Pollutants. J Expo Anal Environ Epidemiol 2001, 11 (3), 231-252. https://doi.org/10.1038/sj.jea.7500165.

(63) Climate at a Glance / National Centers for Environmental Information (NCEI) https://www.ncdc.noaa.gov/cag/national/time-series/110/tavg/ytd/12/18952017?base_prd=true\&firstbaseyear=1901\&lastbaseyear=2000 (accessed Aug 1, 2020).

(64) Murray, D. M.; Burmaster, D. E. Residential Air Exchange Rates in the United States: Empirical and Estimated Parametric Distributions by Season and Climatic Region. Risk Analysis 1995, 15 (4), 459-465. https://doi.org/10.1111/j.1539-6924.1995.tb00338.x.

(65) Offermann, F. Ventilation and Indoor Air Quality in New Homes; CEC-500-2009-085; Public Interest Energy Research (PIER), California Energy Commission and California Air Resources Board, 2009.

(66) Touchie, M. F.; Siegel, J. A. Residential HVAC Runtime from Smart Thermostats: Characterization, Comparison, and Impacts. Indoor Air 2018. https://doi.org/10.1111/ina.12496.

(67) El Orch, Z.; Stephens, B.; Waring, M. S. Predictions and Determinants of Size-Resolved Particle Infiltration Factors in Single-Family Homes in the U.S. Build. Environ. 2014, 74, 106-118. https://doi.org/10.1016/j.buildenv.2014.01.006.

(68) Cetin, K. S.; Novoselac, A. Single and Multi-Family Residential Central All-Air HVAC System Operational Characteristics in Cooling-Dominated Climate. Energy and Buildings 2015, 96, 210220. https://doi.org/10.1016/j.enbuild.2015.03.039. 


\section{SI Appendices}

Table A-1. Primary characteristics of the modeled detached homes (DH)

\begin{tabular}{|c|c|c|c|c|c|c|c|c|c|c|c|c|}
\hline House \# & Floor area $^{1}$ & Year built $^{2}$ & Garage $^{3}$ & Foundation $^{4}$ & \# of Floors ${ }^{5}$ & \# of Bedrooms & \# of Bathrooms & Forced-air $^{6}$ & Heating equipment $^{7}$ & Heating fuel ${ }^{8}$ & Stove fuel $^{9}$ & Weight \\
\hline DH-1 & 1 & 1 & 1 & 3 & 1 & 3 & 1.0 & 2 & $\mathrm{~B}$ & $\mathrm{E}$ & 2 & 224832 \\
\hline DH-2 & 1 & 1 & 2 & 2 & 1 & 2 & 1.0 & 2 & $\mathrm{~S}$ & $\mathrm{G}$ & 1 & 260762 \\
\hline DH-3 & 1 & 1 & 2 & 2 & 2 & 2 & 1.0 & 2 & $\mathrm{~S}$ & $\mathrm{G}$ & 2 & 225744 \\
\hline DH-4 & 1 & 1 & 2 & 3 & 1 & 2 & 1.0 & 2 & $\mathrm{~S}$ & $\mathrm{G}$ & 1 & 724841 \\
\hline DH-5 & 1 & 2 & 1 & 3 & 1 & 2 & 1.0 & 2 & $\mathrm{~B}$ & $\mathrm{E}$ & 2 & 289899 \\
\hline DH-6 & 1 & 2 & 2 & 2 & 1 & 3 & 1.0 & 2 & $\mathrm{~S}$ & $\mathrm{O}$ & 2 & 185831 \\
\hline DH-7 & 1 & 2 & 2 & 3 & 1 & 3 & 1.0 & 2 & B & $\mathrm{E}$ & 2 & 900604 \\
\hline DH-8 & 1 & 3 & 1 & 3 & 1 & 3 & 1.0 & 2 & B & $\mathrm{E}$ & 2 & 367044 \\
\hline DH-9 & 1 & 3 & 2 & 3 & 1 & 3 & 1.0 & 2 & B & $\mathrm{E}$ & 2 & 628095 \\
\hline DH-10 & 1 & 4 & 1 & 3 & 1 & 3 & 2.0 & 2 & B & $E$ & 2 & 227379 \\
\hline DH-11 & 1 & 4 & 2 & 3 & 1 & 3 & 2.0 & 2 & B & $\mathrm{E}$ & 2 & 314950 \\
\hline DH-12 & 2 & 1 & 2 & 1 & 2 & 3 & 2.0 & 2 & $\mathrm{~S}$ & $\mathrm{G}$ & 1 & 159260 \\
\hline DH-13 & 2 & 1 & 2 & 2 & 2 & 3 & 2.0 & 2 & $\mathrm{~S}$ & $\mathrm{G}$ & 2 & 416953 \\
\hline DH-14 & 2 & 1 & 2 & 3 & 1 & 3 & 1.0 & 2 & $\mathrm{~S}$ & $\mathrm{G}$ & 2 & 273653 \\
\hline DH-15 & 2 & 2 & 1 & 3 & 1 & 3 & 1.0 & 2 & B & $E$ & 2 & 193321 \\
\hline DH-16 & 2 & 2 & 2 & 3 & 1 & 3 & 2.0 & 2 & B & $\mathrm{E}$ & 2 & 243360 \\
\hline DH-17 & 2 & 3 & 1 & 3 & 1 & 3 & 2.0 & 2 & $\mathrm{~B}$ & $E$ & 2 & 295006 \\
\hline DH-18 & 2 & 4 & 1 & 3 & 1 & 3 & 2.0 & 2 & B & $\mathrm{E}$ & 2 & 303535 \\
\hline DH-19 & 3 & 1 & 2 & 1 & 2 & 3 & 2.0 & 2 & $\mathrm{~S}$ & $\mathrm{G}$ & 2 & 313160 \\
\hline DH-20 & 3 & 1 & 2 & 2 & 2 & 4 & 2.5 & 2 & $\mathrm{~S}$ & $\mathrm{G}$ & 1 & 279852 \\
\hline DH-21 & 3 & 3 & 1 & 1 & 1 & 4 & 2.5 & 2 & $\mathrm{~S}$ & $\mathrm{G}$ & 2 & 151919 \\
\hline DH-22 & 3 & 4 & 1 & 3 & 1 & 4 & 2.0 & 2 & $\mathrm{~S}$ & $\mathrm{G}$ & 2 & 224890 \\
\hline DH-23 & 3 & 4 & 1 & 3 & 2 & 4 & 3.5 & 2 & $\mathrm{~B}$ & $\mathrm{E}$ & 2 & 277638 \\
\hline DH-24 & 1 & 1 & 1 & 3 & 1 & 3 & 1.0 & 1 & $\mathrm{~F}$ & $\mathrm{G}$ & 1 & 342164 \\
\hline DH-25 & 1 & 1 & 2 & 1 & 1 & 2 & 1.0 & 1 & $\mathrm{~F}$ & $\mathrm{G}$ & 2 & 361178 \\
\hline DH-26 & 1 & 1 & 2 & 2 & 1 & 3 & 1.0 & 1 & $\mathrm{~F}$ & $\mathrm{G}$ & 1 & 1109989 \\
\hline DH-27 & 1 & 1 & 2 & 2 & 2 & 3 & 1.0 & 1 & $\mathrm{~F}$ & $\mathrm{G}$ & 1 & 355111 \\
\hline DH-28 & 1 & 1 & 2 & 3 & 1 & 2 & 1.0 & 1 & $\mathrm{~F}$ & $\mathrm{G}$ & 2 & 942705 \\
\hline DH-29 & 1 & 2 & 1 & 1 & 1 & 3 & 1.0 & 1 & $\mathrm{~F}$ & $\mathrm{G}$ & 2 & 318391 \\
\hline DH-30 & 1 & 2 & 1 & 2 & 1 & 3 & 1.0 & 1 & $\mathrm{~F}$ & $\mathrm{G}$ & 1 & 175478 \\
\hline DH-31 & 1 & 2 & 1 & 3 & 1 & 3 & 2.0 & 1 & $\mathrm{~F}$ & $\mathrm{G}$ & 1 & 1606194 \\
\hline DH-32 & 1 & 2 & 2 & 1 & 1 & 3 & 1.0 & 1 & $\mathrm{~F}$ & $\mathrm{E}$ & 1 & 339650 \\
\hline DH-33 & 1 & 2 & 2 & 2 & 1 & 3 & 1.0 & 1 & $\mathrm{~F}$ & $\mathrm{G}$ & 2 & 475242 \\
\hline DH-34 & 1 & 2 & 2 & 2 & 2 & 3 & 1.5 & 1 & $\mathrm{~F}$ & $\mathrm{O}$ & 2 & 161761 \\
\hline DH-35 & 1 & 2 & 2 & 3 & 1 & 3 & 1.0 & 1 & $\mathrm{~F}$ & $\mathrm{G}$ & 2 & 1621161 \\
\hline DH-36 & 1 & 3 & 1 & 1 & 1 & 3 & 2.0 & 1 & $\mathrm{~F}$ & $\mathrm{G}$ & 1 & 191032 \\
\hline DH-37 & 1 & 3 & 1 & 2 & 1 & 3 & 2.0 & 1 & $\mathrm{~F}$ & $\mathrm{G}$ & 2 & 175975 \\
\hline DH-38 & 1 & 3 & 1 & 3 & 1 & 3 & 2.0 & 1 & $\mathrm{~F}$ & $\mathrm{E}$ & 2 & 2298558 \\
\hline DH-39 & 1 & 3 & 1 & 3 & 2 & 4 & 2.5 & 1 & $\mathrm{~F}$ & $\mathrm{G}$ & 1 & 245114 \\
\hline
\end{tabular}




\begin{tabular}{|c|c|c|c|c|c|c|c|c|c|c|c|c|}
\hline DH-40 & 1 & 3 & 2 & 2 & 1 & 3 & 2.0 & 1 & $\mathrm{~F}$ & $\mathrm{G}$ & 1 & 212618 \\
\hline DH-41 & 1 & 3 & 2 & 3 & 1 & 3 & 1.0 & 1 & $\mathrm{~F}$ & $E$ & 2 & 1126785 \\
\hline DH-42 & 1 & 4 & 1 & 3 & 1 & 3 & 2.0 & 1 & $\mathrm{~F}$ & $E$ & 2 & 1624557 \\
\hline DH-43 & 1 & 4 & 1 & 3 & 2 & 3 & 2.5 & 1 & $\mathrm{~F}$ & $E$ & 2 & 151863 \\
\hline DH-44 & 1 & 4 & 2 & 3 & 1 & 3 & 2.0 & 1 & $\mathrm{~F}$ & $\mathrm{E}$ & 2 & 1373669 \\
\hline DH-45 & 1 & 5 & 1 & 3 & 1 & 3 & 2.0 & 1 & $\mathrm{~F}$ & $\mathrm{G}$ & 2 & 181596 \\
\hline DH-46 & 2 & 1 & 1 & 3 & 1 & 3 & 2.5 & 1 & $\mathrm{~F}$ & $\mathrm{G}$ & 1 & 277522 \\
\hline DH-47 & 2 & 1 & 2 & 1 & 1 & 3 & 1.0 & 1 & $\mathrm{~F}$ & $\mathrm{G}$ & 1 & 188649 \\
\hline DH-48 & 2 & 1 & 2 & 1 & 2 & 3 & 1.0 & 1 & $\mathrm{~F}$ & $\mathrm{G}$ & 2 & 478831 \\
\hline DH-49 & 2 & 1 & 2 & 2 & 2 & 3 & 1.0 & 1 & $\mathrm{~F}$ & $\mathrm{G}$ & 1 & 676072 \\
\hline DH-50 & 2 & 1 & 2 & 3 & 1 & 3 & 2.0 & 1 & $\mathrm{~F}$ & $\mathrm{G}$ & 1 & 497361 \\
\hline DH-51 & 2 & 2 & 1 & 1 & 1 & 3 & 2.0 & 1 & $\mathrm{~F}$ & $\mathrm{G}$ & 2 & 572652 \\
\hline DH-52 & 2 & 2 & 1 & 3 & 1 & 3 & 2.0 & 1 & $\mathrm{~F}$ & $\mathrm{G}$ & 2 & 1008739 \\
\hline DH-53 & 2 & 2 & 2 & 1 & 1 & 3 & 2.0 & 1 & $\mathrm{~F}$ & $\mathrm{G}$ & 2 & 1162932 \\
\hline DH-54 & 2 & 2 & 2 & 1 & 2 & 3 & 1.0 & 1 & $\mathrm{~F}$ & $\mathrm{G}$ & 2 & 209236 \\
\hline DH-55 & 2 & 2 & 2 & 2 & 2 & 4 & 2.5 & 1 & $\mathrm{~F}$ & $\mathrm{G}$ & 1 & 167911 \\
\hline DH-56 & 2 & 2 & 2 & 3 & 1 & 3 & 2.0 & 1 & $\mathrm{~F}$ & $\mathrm{G}$ & 2 & 1239595 \\
\hline DH-57 & 2 & 2 & 2 & 3 & 2 & 3 & 1.5 & 1 & $\mathrm{~F}$ & $\mathrm{G}$ & 1 & 197609 \\
\hline DH-58 & 2 & 3 & 1 & 1 & 1 & 3 & 2.0 & 1 & $\mathrm{~F}$ & $\mathrm{G}$ & 2 & 379112 \\
\hline DH-59 & 2 & 3 & 1 & 1 & 3 & 4 & 2.5 & 1 & $\mathrm{~F}$ & $\mathrm{G}$ & 1 & 164233 \\
\hline DH-60 & 2 & 3 & 1 & 2 & 2 & 4 & 2.5 & 1 & $\mathrm{~F}$ & $\mathrm{G}$ & 1 & 197897 \\
\hline DH-61 & 2 & 3 & 1 & 3 & 1 & 3 & 2.0 & 1 & $\mathrm{~F}$ & $\mathrm{G}$ & 2 & 2059174 \\
\hline DH-62 & 2 & 3 & 1 & 3 & 2 & 3 & 2.5 & 1 & $\mathrm{~F}$ & $\mathrm{G}$ & 2 & 420154 \\
\hline DH-63 & 2 & 3 & 2 & 1 & 1 & 3 & 2.5 & 1 & $\mathrm{~F}$ & $\mathrm{G}$ & 2 & 239528 \\
\hline DH-64 & 2 & 3 & 2 & 3 & 1 & 3 & 2.0 & 1 & $\mathrm{~F}$ & $\mathrm{E}$ & 2 & 659239 \\
\hline DH-65 & 2 & 4 & 1 & 1 & 1 & 4 & 3.5 & 1 & $\mathrm{~F}$ & $\mathrm{G}$ & 2 & 387446 \\
\hline DH-66 & 2 & 4 & 1 & 1 & 2 & 3 & 2.5 & 1 & $\mathrm{~F}$ & $\mathrm{G}$ & 2 & 228463 \\
\hline DH-67 & 2 & 4 & 1 & 2 & 2 & 4 & 2.5 & 1 & $\mathrm{~F}$ & $\mathrm{G}$ & 2 & 353013 \\
\hline DH-68 & 2 & 4 & 1 & 3 & 1 & 3 & 2.0 & 1 & $\mathrm{~F}$ & $\mathrm{G}$ & 2 & 2367386 \\
\hline DH-69 & 2 & 4 & 1 & 3 & 2 & 3 & 2.5 & 1 & $\mathrm{~F}$ & $\mathrm{G}$ & 2 & 786498 \\
\hline DH-70 & 2 & 4 & 2 & 1 & 1 & 3 & 2.5 & 1 & $\mathrm{~F}$ & $E$ & 2 & 193028 \\
\hline DH-71 & 2 & 4 & 2 & 3 & 1 & 4 & 2.0 & 1 & $\mathrm{~F}$ & $\mathrm{G}$ & 2 & 479475 \\
\hline DH-72 & 2 & 5 & 1 & 3 & 1 & 3 & 2.0 & 1 & $\mathrm{~F}$ & $\mathrm{E}$ & 2 & 202628 \\
\hline DH-73 & 3 & 1 & 1 & 1 & 1 & 4 & 1.5 & 1 & $\mathrm{~F}$ & $\mathrm{G}$ & 2 & 206963 \\
\hline DH-74 & 3 & 1 & 1 & 1 & 2 & 3 & 2.5 & 1 & $\mathrm{~F}$ & $\mathrm{G}$ & 1 & 424025 \\
\hline DH-75 & 3 & 1 & 2 & 1 & 1 & 3 & 1.0 & 1 & $\mathrm{~F}$ & $\mathrm{G}$ & 2 & 187935 \\
\hline DH-76 & 3 & 1 & 2 & 1 & 2 & 3 & 2.5 & 1 & $\mathrm{~F}$ & $\mathrm{G}$ & 1 & 1124980 \\
\hline DH-77 & 3 & 1 & 2 & 2 & 2 & 4 & 2.0 & 1 & $\mathrm{~F}$ & $\mathrm{G}$ & 2 & 342676 \\
\hline DH-78 & 3 & 1 & 2 & 3 & 1 & 3 & 2.0 & 1 & $\mathrm{~F}$ & $\mathrm{G}$ & 1 & 152354 \\
\hline DH-79 & 3 & 1 & 2 & 3 & 2 & 3 & 1.0 & 1 & $\mathrm{~F}$ & $\mathrm{G}$ & 2 & 188924 \\
\hline DH-80 & 3 & 2 & 1 & 1 & 1 & 3 & 2.0 & 1 & $\mathrm{~F}$ & $\mathrm{G}$ & 2 & 948161 \\
\hline DH-81 & 3 & 2 & 1 & 1 & 2 & 4 & 2.5 & 1 & $\mathrm{~F}$ & $\mathrm{G}$ & 2 & 583240 \\
\hline DH-82 & 3 & 2 & 1 & 1 & 3 & 3 & 2.5 & 1 & $\mathrm{~F}$ & $\mathrm{G}$ & 1 & 179495 \\
\hline DH-83 & 3 & 2 & 1 & 3 & 1 & 3 & 2.0 & 1 & $\mathrm{~F}$ & $\mathrm{G}$ & 2 & 282832 \\
\hline DH-84 & 3 & 2 & 1 & 3 & 2 & 4 & 2.0 & 1 & $\mathrm{~F}$ & $\mathrm{G}$ & 1 & 172310 \\
\hline
\end{tabular}




\begin{tabular}{|c|c|c|c|c|c|c|c|c|c|c|c|c|}
\hline DH-85 & 3 & 2 & 2 & 1 & 1 & 4 & 2.0 & 1 & $\mathrm{~F}$ & $\mathrm{G}$ & 1 & 513106 \\
\hline DH-86 & 3 & 2 & 2 & 1 & 2 & 4 & 2.5 & 1 & $\mathrm{~F}$ & $\mathrm{G}$ & 1 & 360603 \\
\hline DH-87 & 3 & 2 & 2 & 3 & 1 & 3 & 2.0 & 1 & $\mathrm{~F}$ & $\mathrm{G}$ & 2 & 382444 \\
\hline DH-88 & 3 & 3 & 1 & 1 & 1 & 3 & 2.0 & 1 & $\mathrm{~F}$ & $\mathrm{G}$ & 2 & 885254 \\
\hline DH-89 & 3 & 3 & 1 & 1 & 2 & 4 & 2.5 & 1 & $\mathrm{~F}$ & $\mathrm{G}$ & 2 & 1174102 \\
\hline DH-90 & 3 & 3 & 1 & 1 & 3 & 3 & 2.0 & 1 & $\mathrm{~F}$ & $\mathrm{G}$ & 1 & 267352 \\
\hline DH-91 & 3 & 3 & 1 & 2 & 2 & 4 & 2.5 & 1 & $\mathrm{~F}$ & $\mathrm{G}$ & 1 & 228768 \\
\hline DH-92 & 3 & 3 & 1 & 3 & 1 & 3 & 2.0 & 1 & $\mathrm{~F}$ & $\mathrm{G}$ & 2 & 588272 \\
\hline DH-93 & 3 & 3 & 1 & 3 & 2 & 4 & 3.5 & 1 & $\mathrm{~F}$ & $\mathrm{G}$ & 2 & 1052494 \\
\hline DH-94 & 3 & 3 & 2 & 1 & 2 & 3 & 2.5 & 1 & $\mathrm{~F}$ & $\mathrm{G}$ & 2 & 399927 \\
\hline DH-95 & 3 & 3 & 2 & 3 & 1 & 3 & 2.0 & 1 & $\mathrm{~F}$ & $\mathrm{E}$ & 2 & 163648 \\
\hline DH-96 & 3 & 3 & 2 & 3 & 2 & 3 & 2.5 & 1 & $\mathrm{~F}$ & $\mathrm{G}$ & 2 & 310493 \\
\hline DH-97 & 3 & 4 & 1 & 1 & 1 & 4 & 3.0 & 1 & $\mathrm{~F}$ & $\mathrm{G}$ & 2 & 1186840 \\
\hline DH-98 & 3 & 4 & 1 & 1 & 2 & 4 & 3.5 & 1 & $\mathrm{~F}$ & $\mathrm{G}$ & 2 & 2605058 \\
\hline DH-99 & 3 & 4 & 1 & 1 & 3 & 3 & 2.0 & 1 & $\mathrm{~F}$ & $\mathrm{G}$ & 2 & 261025 \\
\hline DH-100 & 3 & 4 & 1 & 2 & 2 & 4 & 2.5 & 1 & $\mathrm{~F}$ & $\mathrm{G}$ & 2 & 465855 \\
\hline DH-101 & 3 & 4 & 1 & 3 & 1 & 3 & 2.0 & 1 & $\mathrm{~F}$ & $\mathrm{G}$ & 2 & 1334713 \\
\hline DH-102 & 3 & 4 & 1 & 3 & 2 & 4 & 3.5 & 1 & $\mathrm{~F}$ & $\mathrm{G}$ & 1 & 2516276 \\
\hline DH-103 & 3 & 4 & 2 & 3 & 1 & 4 & 2.0 & 1 & $\mathrm{~F}$ & $E$ & 2 & 176536 \\
\hline DH-104 & 3 & 4 & 2 & 3 & 2 & 4 & 2.5 & 1 & $\mathrm{~F}$ & $\mathrm{E}$ & 2 & 413066 \\
\hline DH-105 & 3 & 5 & 1 & 1 & 2 & 4 & 3.5 & 1 & $\mathrm{~F}$ & $\mathrm{G}$ & 2 & 187057 \\
\hline DH-106 & 3 & 5 & 1 & 3 & 1 & 3 & 3.0 & 1 & $\mathrm{~F}$ & $E$ & 2 & 247418 \\
\hline DH-107 & 3 & 5 & 1 & 3 & 2 & 4 & 3.5 & 1 & $\mathrm{~F}$ & $\mathrm{G}$ & 2 & 419245 \\
\hline
\end{tabular}

${ }^{1}$ Floor Area: $1=$ less than $149 \mathrm{~m}^{2}, 2=$ more than $149 \mathrm{~m}^{2}$ less than $223 \mathrm{~m}^{2}$, and $3=$ more than $223 \mathrm{~m}^{2}$

${ }^{2}$ Year built: $1=<1950,2=1950-1969,3=1970-1989,4=1990-2009$, and $5=2010-2015$

${ }^{3}$ Garage: 1 = with garage, and $2=$ without garage

${ }^{4}$ Foundation type: 1 = Finished basement, 2 = Unfinished basement, $3=$ No basement

5 \# of Floors: 1, 2, or 3 story buildings

${ }^{6}$ Forced Air: 1 = with forced-air system, and $2=$ without forced-air system

${ }^{7}$ Heating system: $\mathrm{F}=$ Furnace, $\mathrm{HP}=$ Heat pump, $\mathrm{S}=$ Steam boiler, and $\mathrm{B}=$ baseboard

${ }^{8}$ Heating fuel: $\mathrm{G}=\mathrm{Gas}, \mathrm{E}=$ Electric, and $\mathrm{O}=\mathrm{Oil}$

${ }^{9}$ Stove type: $1=$ Gas stove, 2 = Electric stove 
Table A-2. Primary characteristics of the modeled attached homes (AH)

\begin{tabular}{|c|c|c|c|c|c|c|c|c|c|c|c|c|}
\hline House \# & Floor area & Year built & Garage & Foundation & \# of Floors & \# of Bedrooms & \# of Bathrooms & Forced-air & Heating equipment & Heating fuel & Stove fuel & Weight \\
\hline AH-1 & 2 & 1 & 1 & 2 & 2 & 2 & 3 & 1.5 & $\mathrm{~S}$ & $\mathrm{G}$ & 1 & 65285 \\
\hline AH-2 & 2 & 1 & 1 & 2 & 3 & 1 & 2 & 1 & $\mathrm{~B}$ & $E$ & 2 & 47231 \\
\hline AH-3 & 2 & 1 & 2 & 1 & 3 & 2 & 2 & 1 & $\mathrm{~S}$ & $\mathrm{G}$ & 1 & 40509 \\
\hline AH-4 & 2 & 1 & 2 & 2 & 1 & 2 & 2 & 1.5 & $\mathrm{~S}$ & $\mathrm{G}$ & 1 & 96801 \\
\hline AH-5 & 2 & 1 & 2 & 2 & 3 & 1 & 2 & 1 & $\mathrm{~B}$ & $\mathrm{E}$ & 2 & 172548 \\
\hline AH-6 & 2 & 1 & 2 & 2 & 3 & 2 & 3 & 1 & $\mathrm{~S}$ & $\mathrm{G}$ & 2 & 32513 \\
\hline AH-7 & 2 & 1 & 3 & 1 & 3 & 2 & 3 & 2.5 & $\mathrm{~B}$ & $\mathrm{E}$ & 2 & 45106 \\
\hline AH-8 & 2 & 1 & 3 & 2 & 3 & 1 & 2 & 1 & $\mathrm{~B}$ & $E$ & 2 & 56186 \\
\hline AH-9 & 2 & 1 & 3 & 2 & 3 & 2 & 2 & 1.5 & B & $\mathrm{E}$ & 1 & 83433 \\
\hline AH-10 & 2 & 1 & 4 & 1 & 3 & 1 & 2 & 2 & $\mathrm{~B}$ & $\mathrm{E}$ & 2 & 30013 \\
\hline AH-11 & 2 & 1 & 4 & 1 & 3 & 2 & 2 & 1 & B & $E$ & 2 & 44138 \\
\hline AH-12 & 2 & 1 & 4 & 2 & 3 & 1 & 2 & 1 & $\mathrm{~B}$ & $E$ & 2 & 44163 \\
\hline AH-13 & 2 & 1 & 4 & 2 & 3 & 2 & 2 & 1.5 & $\mathrm{~B}$ & $E$ & 2 & 56203 \\
\hline AH-14 & 2 & 2 & 1 & 1 & 1 & 3 & 5 & 2.5 & $\mathrm{~S}$ & $\mathrm{G}$ & 1 & 35489 \\
\hline AH-15 & 2 & 2 & 1 & 1 & 3 & 2 & 3 & 2 & $\mathrm{~S}$ & $\mathrm{G}$ & 1 & 38324 \\
\hline AH-16 & 2 & 2 & 1 & 2 & 1 & 2 & 4 & 1 & $\mathrm{~S}$ & $\mathrm{G}$ & 1 & 25457 \\
\hline AH-17 & 2 & 2 & 1 & 2 & 1 & 3 & 3 & 1 & $\mathrm{~S}$ & $\mathrm{G}$ & 1 & 40721 \\
\hline AH-18 & 2 & 2 & 1 & 2 & 2 & 2 & 3 & 3 & $\mathrm{~B}$ & $\mathrm{E}$ & 2 & 94705 \\
\hline AH-19 & 2 & 3 & 1 & 2 & 1 & 2 & 2 & 1.5 & $\mathrm{~B}$ & $\mathrm{E}$ & 2 & 61335 \\
\hline AH-20 & 2 & 3 & 3 & 1 & 1 & 2 & 3 & 2.5 & $\mathrm{~S}$ & $\mathrm{G}$ & 2 & 27994 \\
\hline AH-21 & 1 & 1 & 1 & 2 & 1 & 2 & 3 & 1.5 & $\mathrm{~F}$ & $\mathrm{G}$ & 1 & 94794 \\
\hline AH-22 & 1 & 1 & 1 & 2 & 2 & 2 & 3 & 1 & $\mathrm{~F}$ & $\mathrm{G}$ & 1 & 142466 \\
\hline AH-23 & 1 & 1 & 1 & 2 & 3 & 2 & 2 & 1 & $\mathrm{~F}$ & $\mathrm{G}$ & 2 & 42751 \\
\hline AH-24 & 1 & 1 & 2 & 1 & 3 & 1 & 2 & 1 & $\mathrm{~F}$ & $\mathrm{G}$ & 2 & 42649 \\
\hline AH-25 & 1 & 1 & 2 & 2 & 1 & 2 & 3 & 1 & $\mathrm{~F}$ & $\mathrm{G}$ & 1 & 77650 \\
\hline AH-26 & 1 & 1 & 2 & 2 & 2 & 1 & 3 & 1 & $\mathrm{~F}$ & $\mathrm{G}$ & 1 & 36675 \\
\hline AH-27 & 1 & 1 & 2 & 2 & 2 & 2 & 3 & 1 & $\mathrm{~F}$ & $\mathrm{G}$ & 1 & 42691 \\
\hline AH-28 & 1 & 1 & 2 & 2 & 2 & 3 & 4 & 1 & $\mathrm{~F}$ & $\mathrm{G}$ & 1 & 85221 \\
\hline AH-29 & 1 & 1 & 2 & 2 & 3 & 1 & 2 & 1 & $\mathrm{~F}$ & $\mathrm{G}$ & 2 & 191282 \\
\hline AH-30 & 1 & 1 & 2 & 2 & 3 & 2 & 2 & 2.5 & $\mathrm{~F}$ & $E$ & 2 & 45460 \\
\hline AH-31 & 1 & 1 & 3 & 1 & 2 & 1 & 2 & 1 & $\mathrm{~F}$ & $\mathrm{G}$ & 2 & 23349 \\
\hline AH-32 & 1 & 1 & 3 & 1 & 3 & 1 & 2 & 2 & $\mathrm{~F}$ & $E$ & 2 & 212532 \\
\hline AH-33 & 1 & 1 & 3 & 1 & 3 & 2 & 2 & 2.5 & $\mathrm{~F}$ & $E$ & 2 & 160078 \\
\hline AH-34 & 1 & 1 & 3 & 2 & 1 & 2 & 2 & 1 & $\mathrm{~F}$ & $\mathrm{E}$ & 2 & 45026 \\
\hline AH-35 & 1 & 1 & 3 & 2 & 2 & 2 & 3 & 1.5 & $\mathrm{~F}$ & $\mathrm{G}$ & 1 & 134868 \\
\hline AH-36 & 1 & 1 & 3 & 2 & 3 & 1 & 2 & 1 & $\mathrm{~F}$ & $\mathrm{E}$ & 1 & 224812 \\
\hline AH-37 & 1 & 1 & 3 & 2 & 3 & 2 & 2 & 1.5 & $\mathrm{~F}$ & $\mathrm{G}$ & 2 & 314009 \\
\hline AH-38 & 1 & 1 & 4 & 1 & 1 & 1 & 2 & 2.5 & $\mathrm{~F}$ & $\mathrm{G}$ & 2 & 37822 \\
\hline AH-39 & 1 & 1 & 4 & 1 & 3 & 1 & 2 & 2 & $\mathrm{~F}$ & $E$ & 2 & 171143 \\
\hline AH-40 & 1 & 1 & 4 & 1 & 3 & 2 & 3 & 2.5 & $\mathrm{~F}$ & $\mathrm{G}$ & 2 & 217491 \\
\hline AH-41 & 1 & 1 & 4 & 2 & 2 & 2 & 3 & 2.5 & $\mathrm{~F}$ & $E$ & 2 & 28080 \\
\hline AH-42 & 1 & 1 & 4 & 2 & 2 & 3 & 2 & 1 & $\mathrm{~F}$ & $\mathrm{G}$ & 1 & 49649 \\
\hline AH-43 & 1 & 1 & 4 & 2 & 3 & 1 & 2 & 1 & $\mathrm{~F}$ & $\mathrm{E}$ & 2 & 88285 \\
\hline
\end{tabular}




\begin{tabular}{|c|c|c|c|c|c|c|c|c|c|c|c|c|}
\hline AH-44 & 1 & 1 & 4 & 2 & 3 & 2 & 2 & 1.5 & $\mathrm{~F}$ & $\mathrm{E}$ & 2 & 208203 \\
\hline AH-45 & 1 & 1 & 5 & 1 & 3 & 1 & 2 & 2 & $\mathrm{~F}$ & $\mathrm{G}$ & 2 & 54015 \\
\hline AH-46 & 1 & 2 & 1 & 2 & 1 & 1 & 3 & 2 & $\mathrm{~F}$ & $\mathrm{G}$ & 1 & 36714 \\
\hline AH-47 & 1 & 2 & 1 & 2 & 1 & 2 & 3 & 1.5 & $\mathrm{~F}$ & $\mathrm{G}$ & 1 & 158835 \\
\hline AH-48 & 1 & 2 & 2 & 1 & 1 & 2 & 3 & 1.5 & $\mathrm{~F}$ & $\mathrm{G}$ & 1 & 33330 \\
\hline AH-49 & 1 & 2 & 3 & 1 & 1 & 1 & 2 & 2 & $\mathrm{~F}$ & $\mathrm{G}$ & 2 & 62624 \\
\hline AH-50 & 1 & 2 & 3 & 1 & 1 & 2 & 3 & 2.5 & $\mathrm{~F}$ & $\mathrm{G}$ & 2 & 33993 \\
\hline AH-51 & 1 & 2 & 3 & 1 & 3 & 1 & 3 & 2 & $\mathrm{~F}$ & $\mathrm{G}$ & 2 & 82483 \\
\hline AH-52 & 1 & 2 & 3 & 1 & 3 & 2 & 3 & 2.5 & $\mathrm{~F}$ & $\mathrm{G}$ & 2 & 81458 \\
\hline AH-54 & 1 & 2 & 3 & 2 & 1 & 2 & 3 & 3.5 & $\mathrm{~F}$ & $\mathrm{E}$ & 2 & 57669 \\
\hline AH-55 & 1 & 2 & 3 & 2 & 1 & 3 & 3 & 3 & $\mathrm{~F}$ & $\mathrm{E}$ & 2 & 37524 \\
\hline AH-56 & 1 & 2 & 3 & 2 & 3 & 1 & 2 & 2 & $\mathrm{~F}$ & $E$ & 2 & 55146 \\
\hline AH-57 & 1 & 2 & 3 & 2 & 3 & 3 & 2 & 2 & $\mathrm{~F}$ & $\mathrm{G}$ & 1 & 28725 \\
\hline AH-58 & 1 & 2 & 4 & 1 & 1 & 1 & 2 & 3 & $\mathrm{~F}$ & $\mathrm{G}$ & 1 & 49797 \\
\hline AH-59 & 1 & 2 & 4 & 1 & 1 & 2 & 3 & 2.5 & $\mathrm{~F}$ & $\mathrm{G}$ & 2 & 61101 \\
\hline AH-60 & 1 & 2 & 4 & 1 & 2 & 2 & 3 & 2.5 & $\mathrm{~F}$ & $\mathrm{G}$ & 2 & 28690 \\
\hline AH-61 & 1 & 2 & 4 & 1 & 2 & 3 & 3 & 3.5 & $\mathrm{~F}$ & $\mathrm{G}$ & 1 & 45699 \\
\hline AH-62 & 1 & 2 & 4 & 1 & 3 & 1 & 2 & 2 & $\mathrm{~F}$ & $\mathrm{G}$ & 1 & 77205 \\
\hline AH-64 & 1 & 2 & 4 & 1 & 3 & 3 & 3 & 2.5 & $\mathrm{~F}$ & $\mathrm{G}$ & 1 & 68916 \\
\hline AH-65 & 1 & 2 & 4 & 2 & 1 & 2 & 2 & 1.5 & $\mathrm{~F}$ & $\mathrm{G}$ & 1 & 32682 \\
\hline AH-66 & 1 & 2 & 4 & 2 & 3 & 2 & 3 & 2.5 & $\mathrm{~F}$ & $\mathrm{G}$ & 1 & 50835 \\
\hline AH-67 & 1 & 2 & 5 & 1 & 3 & 2 & 3 & 2.5 & $\mathrm{~F}$ & $\mathrm{G}$ & 2 & 39841 \\
\hline AH-68 & 1 & 3 & 1 & 1 & 1 & 2 & 3 & 1.5 & $\mathrm{~F}$ & $\mathrm{G}$ & 1 & 37504 \\
\hline AH-69 & 1 & 3 & 1 & 2 & 1 & 2 & 3 & 1.5 & $\mathrm{~F}$ & $\mathrm{G}$ & 1 & 58310 \\
\hline AH-70 & 1 & 3 & 1 & 2 & 2 & 2 & 6 & 1.5 & $\mathrm{~F}$ & $\mathrm{O}$ & 2 & 27752 \\
\hline AH-71 & 1 & 3 & 2 & 1 & 3 & 2 & 4 & 2.5 & $\mathrm{HP}$ & $E$ & 2 & 22871 \\
\hline AH-72 & 1 & 3 & 3 & 1 & 3 & 2 & 3 & 2.5 & $\mathrm{~F}$ & $\mathrm{G}$ & 1 & 34774 \\
\hline AH-73 & 1 & 3 & 3 & 2 & 1 & 2 & 3 & 2.5 & $\mathrm{~F}$ & $\mathrm{G}$ & 2 & 82405 \\
\hline AH-74 & 1 & 3 & 4 & 1 & 1 & 1 & 3 & 2 & $\mathrm{~F}$ & $\mathrm{G}$ & 1 & 68025 \\
\hline AH-75 & 1 & 3 & 4 & 1 & 1 & 2 & 3 & 2.5 & $\mathrm{~F}$ & $\mathrm{G}$ & 1 & 83648 \\
\hline AH-76 & 1 & 3 & 4 & 1 & 3 & 2 & 3 & 2.5 & $\mathrm{~F}$ & $\mathrm{E}$ & 2 & 48930 \\
\hline AH-77 & 1 & 3 & 5 & 1 & 1 & 1 & 3 & 3 & $\mathrm{~F}$ & $\mathrm{G}$ & 2 & 29002 \\
\hline AH-78 & 1 & 3 & 5 & 1 & 1 & 2 & 3 & 3 & $\mathrm{~F}$ & $\mathrm{G}$ & 1 & 26532 \\
\hline AH-79 & 1 & 3 & 5 & 1 & 3 & 2 & 3 & 3.5 & $\mathrm{~F}$ & $\mathrm{G}$ & 1 & 30401 \\
\hline
\end{tabular}

${ }^{1}$ Floor Area: $1=$ less than $149 \mathrm{~m}^{2}, 2=$ more than $149 \mathrm{~m}^{2}$ less than $223 \mathrm{~m}^{2}$, and $3=$ more than $223 \mathrm{~m}^{2} ;{ }^{2}$ Year built: $1=<1950,2=1950-1969,3=1970-1989,4=1990-2009$, and $5=$ 2010-2015; ${ }^{3}$ Garage: $1=$ with garage, and $2=$ without garage $;{ }^{4}$ Foundation type: $1=$ Finished basement, $2=$ Unfinished basement, $3=$ No basement; ${ }^{5} \#$ of Floors: 1,2 , or 3 story buildings; ${ }^{6}$ Forced Air: $1=$ with forced-air system, and $2=$ without forced-air system; ${ }^{7}$ Heating system: $\mathrm{F}=$ Furnace, $\mathrm{HP}=\mathrm{Heat}$ pump, $\mathrm{S}=\mathrm{Steam}$ boiler, and $\mathrm{B}=$ baseboard; ${ }^{8}$

Heating fuel: $\mathrm{G}=\mathrm{Gas}, \mathrm{E}=$ Electric, and $\mathrm{O}=\mathrm{Oil} ;{ }^{9}$ Stove type: 1 = Gas stove, $2=$ Electric stove 
Table A-3. Primary characteristics of the modeled apartment units (APT)

\begin{tabular}{|c|c|c|c|c|c|c|c|c|c|c|}
\hline House \# & \# of units ${ }^{1}$ & Floor area $^{2}$ & Year built $^{3}$ & \# of Bedrooms & \# of Bathrooms & Forced-air $^{4}$ & Heating equipment $^{5}$ & Heating fuel $^{6}$ & Stove fuel $^{7}$ & Weight \\
\hline APT-1 & 1 & 1 & 1 & 2 & 1 & 2 & $\mathrm{~S}$ & $\mathrm{G}$ & 1 & 702158 \\
\hline APT-2 & 1 & 1 & 1 & 2 & 1 & 1 & $\mathrm{~F}$ & $\mathrm{G}$ & 1 & 690412 \\
\hline APT-3 & 1 & 1 & 2 & 1 & 1 & 2 & B & $\mathrm{E}$ & 2 & 565951 \\
\hline APT-4 & 1 & 1 & 2 & 2 & 1 & 1 & $\mathrm{~F}$ & $\mathrm{G}$ & 2 & 538451 \\
\hline APT-5 & 1 & 1 & 3 & 2 & 1 & 2 & B & $E$ & 2 & 709371 \\
\hline APT-6 & 1 & 1 & 3 & 2 & 1 & 1 & $\mathrm{~F}$ & $\mathrm{E}$ & 2 & 887811 \\
\hline APT-7 & 1 & 1 & 4 & 2 & 1 & 1 & $\mathrm{~F}$ & $\mathrm{E}$ & 2 & 537679 \\
\hline APT-8 & 1 & 2 & 1 & 2 & 1 & 2 & $\mathrm{~S}$ & $\mathrm{G}$ & 1 & 686036 \\
\hline APT-9 & 1 & 2 & 1 & 2 & 1 & 1 & $\mathrm{~F}$ & $\mathrm{G}$ & 1 & 730856 \\
\hline APT-10 & 1 & 2 & 2 & 2 & 1 & 1 & $\mathrm{~F}$ & $\mathrm{G}$ & 2 & 513702 \\
\hline APT-11 & 1 & 2 & 4 & 2 & 2 & 1 & $\mathrm{~F}$ & $\mathrm{G}$ & 2 & 712805 \\
\hline APT-12 & 2 & 1 & 1 & 1 & 1 & 2 & $\mathrm{~S}$ & $\mathrm{G}$ & 1 & 1981621 \\
\hline APT-13 & 2 & 1 & 1 & 1 & 1 & 1 & $\mathrm{~F}$ & $\mathrm{G}$ & 2 & 581246 \\
\hline APT-14 & 2 & 1 & 2 & 1 & 1 & 2 & $S$ & $\mathrm{G}$ & 2 & 1492212 \\
\hline APT-15 & 2 & 1 & 2 & 1 & 1 & 1 & $\mathrm{~F}$ & $\mathrm{G}$ & 1 & 1213312 \\
\hline APT-16 & 2 & 1 & 3 & 1 & 1 & 2 & $\mathrm{~B}$ & $E$ & 2 & 1852299 \\
\hline APT-17 & 2 & 1 & 3 & 1 & 1 & 1 & $\mathrm{~F}$ & $\mathrm{E}$ & 2 & 2861738 \\
\hline APT-18 & 2 & 1 & 4 & 1 & 1 & 2 & $\mathrm{~B}$ & $\mathrm{E}$ & 2 & 1231593 \\
\hline APT-19 & 2 & 1 & 4 & 1 & 1 & 1 & $\mathrm{~F}$ & $\mathrm{E}$ & 2 & 1498942 \\
\hline APT-20 & 2 & 2 & 3 & 2 & 1 & 2 & $\mathrm{~S}$ & $\mathrm{E}$ & 2 & 611063 \\
\hline APT-21 & 2 & 2 & 3 & 2 & 2 & 1 & $\mathrm{~F}$ & $\mathrm{E}$ & 2 & 1486617 \\
\hline APT-22 & 2 & 2 & 4 & 2 & 1 & 2 & $\mathrm{~B}$ & $\mathrm{E}$ & 2 & 778676 \\
\hline APT-23 & 2 & 2 & 4 & 2 & 2 & 1 & $\mathrm{~F}$ & $E$ & 2 & 1569853 \\
\hline
\end{tabular}

${ }^{1}$ Number of units: $1=2$ to 4 units and $2=5$ or more units

${ }^{2}$ Floor Area: $1=$ less than $149 \mathrm{~m}^{2}, 2=$ more than $149 \mathrm{~m}^{2}$ less than $223 \mathrm{~m}^{2}$, and $3=$ more than $223 \mathrm{~m}^{2}$

${ }^{3}$ Year built: $1=<1950,2=1950-1969,3=1970-1989,4=1990-2009$, and $5=2010-2015$

${ }^{4}$ Forced Air: $1=$ with forced-air system, and $2=$ without forced-air system

${ }^{5}$ Heating system: $\mathrm{F}=$ Furnace, $\mathrm{HP}=$ Heat pump, $\mathrm{S}=$ Steam boiler, and $\mathrm{B}=$ baseboard

${ }^{6}$ Heating fuel: $\mathrm{G}=\mathrm{Gas}, \mathrm{E}=$ Electric, and $\mathrm{O}=$ Oil

${ }^{7}$ Stove type: $1=$ Gas stove, 2 = Electric stove 
Table A-4. Primary characteristics of the modeled manufactured homes (MH)

\begin{tabular}{|c|c|c|c|c|c|c|c|c|c|}
\hline House \# & 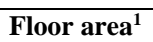 & Year built ${ }^{2}$ & \# of Bedrooms & \# of Bathrooms & Forced-air $^{3}$ & Heating equipment $^{4}$ & Heating fuel $^{5}$ & Stove fuel $^{6}$ & Weight \\
\hline MH-1 & 1 & 2 & 2 & 1 & 1 & $\mathrm{~F}$ & $\mathrm{G}$ & 1 & 309663 \\
\hline MH-2 & 1 & 3 & 2 & 1 & 2 & B & $\mathrm{E}$ & 2 & 947532 \\
\hline MH-3 & 1 & 3 & 3 & 2 & 1 & $\mathrm{~F}$ & $\mathrm{E}$ & 2 & 1594989 \\
\hline MH-4 & 1 & 4 & 2 & 1 & 2 & B & $\mathrm{E}$ & 2 & 529503 \\
\hline MH-5 & 1 & 4 & 3 & 2 & 1 & $\mathrm{~F}$ & $E$ & 2 & 1656194 \\
\hline MH-6 & 2 & 4 & 3 & 2 & 1 & $\mathrm{~F}$ & $\mathrm{E}$ & 2 & 511289 \\
\hline
\end{tabular}

${ }^{1}$ Floor Area: $1=$ less than $149 \mathrm{~m}^{2}, 2=$ more than $149 \mathrm{~m}^{2}$ less than $223 \mathrm{~m}^{2}$, and $3=$ more than $223 \mathrm{~m}^{2}$

${ }^{2}$ Year built: $1=<1950,2=1950-1969,3=1970-1989,4=1990-2009$, and $5=2010-2015$

${ }^{3}$ Forced Air: $1=$ with forced-air system, and $2=$ without forced-air system

${ }^{4}$ Heating system: $\mathrm{F}=$ Furnace, $\mathrm{HP}=$ Heat pump, $\mathrm{S}=$ Steam boiler, and $\mathrm{B}=$ baseboard

${ }^{5}$ Heating fuel: $\mathrm{G}=\mathrm{Gas}, \mathrm{E}=$ Electric, and $\mathrm{O}=\mathrm{Oil}$

${ }^{6}$ Stove type: $1=$ Gas stove, 2 = Electric stove 
Table A-5. Home characteristics by climate zone and year of construction

\begin{tabular}{|c|c|c|c|c|c|c|}
\hline City & \multicolumn{6}{|c|}{ Atlanta, GA } \\
\hline Home vintage & $<1950$ & $1950-1969$ & 1970-1989 & 1990-2009 & $\begin{array}{c}2010-2015 \\
(2010-2029)\end{array}$ & $2030-2050$ \\
\hline $\begin{array}{c}\text { Floor } \\
\text { Insulation } \\
\left(\mathbf{m}^{2} \mathbf{K} / \mathbf{W}\right) \\
\end{array}$ & Uninsulated & Uninsulated & 3.3 (R-19) & $3.3(\mathrm{R}-19)$ & 3.3 (R-19) & $3.7(\mathrm{R}-21)$ \\
\hline $\begin{array}{c}\text { Exterior Wall } \\
\text { Material }\end{array}$ & Wood, light & Brick & Aluminum & Vinyl, light & Vinyl, light & Vinyl, light \\
\hline $\begin{array}{c}\text { Wall insulation } \\
\left(\mathbf{m}^{2} \mathbf{K} / \mathbf{W}\right)\end{array}$ & Uninsulated & Uninsulated & 1.9 (R-11) & 1.9 (R-13) & 4.9 (R-28) & 6.3 (R-36) \\
\hline $\begin{array}{c}\text { Wall } \\
\text { Characteristics }\end{array}$ & $\begin{array}{c}\text { Fiberglass batt } \\
\text { Gr- } 1,2 \times 4, \\
16 \text { in o.c. }\end{array}$ & $\begin{array}{c}\text { Fiberglass batt } \\
\text { Gr- } 1,2 \times 4, \\
16 \text { in o.c. }\end{array}$ & $\begin{array}{c}\text { Fiberglass batt } \\
\text { Gr- } 1,2 \times 4, \\
16 \text { in o.c. }\end{array}$ & $\begin{array}{c}\text { Fiberglass batt } \\
\text { Gr- } 1,2 \times 4, \\
16 \text { in o.c. }\end{array}$ & $\begin{array}{c}\text { Fiberglass batt } \\
\text { Gr- } 1,2 \times 4, \\
16 \text { in o.c. }\end{array}$ & $\begin{array}{c}\text { Fiberglass batt } \\
\text { Gr- } 1,2 \mathrm{x} 4 \\
16 \text { in o.c }\end{array}$ \\
\hline $\begin{array}{c}\text { Attic } \\
\text { Insulation } \\
\left(\mathbf{m}^{2} \mathbf{K} / \mathbf{W}\right) \\
\end{array}$ & Uninsulated & $1.3(\mathrm{R}-7)$ & 4.7 (R-27) & 5.3 (R-30) & 6.7 (R-38) & $8.6(\mathrm{R}-49)$ \\
\hline $\begin{array}{c}\text { Window U- } \\
\text { Value }\left(W / m^{2} K\right)\end{array}$ & 5.3 & 6.0 & 3.4 & 3.1 & 2.0 & 1.7 \\
\hline $\begin{array}{l}\text { Window } \\
\text { SHGC }\end{array}$ & 0.72 & 0.73 & 0.65 & 0.4 & 0.25 & 0.22 \\
\hline $\begin{array}{c}\text { Duct Insulation } \\
\left(\mathrm{m}^{2} \mathrm{~K} / \mathrm{W}\right)\end{array}$ & 0.7 (R-4) & 0.7 (R-4) & 0.9 (R-5) & 0.9 (R-5) & $1.4(\mathrm{R}-8)$ & $1.4(\mathrm{R}-8)$ \\
\hline City & & & Birmin & am, AL & & \\
\hline Home vintage & $<1950$ & $1950-1969$ & 1970-1989 & 1990-2009 & $\begin{array}{c}2010-2015 \\
(2010-2029)\end{array}$ & $2030-2050$ \\
\hline $\begin{array}{c}\text { Floor } \\
\text { Insulation } \\
\left(\mathbf{m}^{2} \mathbf{K} / \mathbf{W}\right)\end{array}$ & Uninsulated & Uninsulated & Uninsulated & 3.4 (R-19) & 3.4 (R-19) & 3.7 (R-21) \\
\hline $\begin{array}{c}\text { Exterior Wall } \\
\text { Material }\end{array}$ & Wood, light & Brick & Aluminum & Vinyl, light & Vinyl, light & Vinyl, light \\
\hline $\begin{array}{c}\text { Wall insulation } \\
\left(\mathbf{m}^{2} \mathbf{K} / \mathbf{W}\right)\end{array}$ & Uninsulated & Uninsulated & $1.9(\mathrm{R}-11)$ & $2.3(\mathrm{R}-13)$ & 4.9 (R-28) & $6.3(\mathrm{R}-36)$ \\
\hline $\begin{array}{c}\text { Wall } \\
\text { Characteristics }\end{array}$ & $\begin{array}{c}\text { Fiberglass batt } \\
\text { Gr- } 1,2 \times 4, \\
16 \text { in o.c. }\end{array}$ & $\begin{array}{c}\text { Fiberglass batt } \\
\text { Gr- } 1,2 \times 4, \\
16 \text { in o.c. }\end{array}$ & $\begin{array}{c}\text { Fiberglass batt } \\
\text { Gr- } 1,2 \times 4, \\
16 \text { in o.c. }\end{array}$ & $\begin{array}{c}\text { Fiberglass batt } \\
\text { Gr- } 1,2 \times 4, \\
16 \text { in o.c. }\end{array}$ & $\begin{array}{c}\text { Fiberglass batt } \\
\text { Gr- } 1,2 \times 4, \\
16 \text { in o.c. }\end{array}$ & $\begin{array}{c}\text { Fiberglass batt } \\
\text { Gr-1, } 2 \times 4, \\
16 \text { in o.c. }\end{array}$ \\
\hline $\begin{array}{c}\text { Attic } \\
\text { Insulation } \\
\left(\mathbf{m}^{2} \mathbf{K} / \mathbf{W}\right) \\
\end{array}$ & Uninsulated & $1.2(\mathrm{R}-7)$ & $4.8(\mathrm{R}-27)$ & $5.3(\mathrm{R}-30)$ & $6.7(\mathrm{R}-38)$ & $8.6(\mathrm{R}-49)$ \\
\hline $\begin{array}{c}\text { Window U- } \\
\text { Value }\left(W / \mathbf{m}^{2} \mathbf{K}\right) \\
\end{array}$ & 3.1 & 3.5 & 2.6 & 3.4 & 2 & 1.7 \\
\hline $\begin{array}{c}\text { Window } \\
\text { SHGC }\end{array}$ & 0.65 & 0.66 & 0.59 & 0.4 & 0.25 & 0.22 \\
\hline $\begin{array}{c}\text { Duct Insulation } \\
\left(\mathrm{m}^{2} \mathrm{~K} / \mathrm{W}\right)\end{array}$ & 0.7 (R-4) & 0.7 (R-4) & $0.9(\mathrm{R}-5)$ & $0.9(\mathrm{R}-5)$ & $1.4(\mathrm{R}-8)$ & $1.4(\mathrm{R}-8)$ \\
\hline
\end{tabular}


Table A-5 (continued). Home characteristics by climate zone and year of construction

\begin{tabular}{|c|c|c|c|c|c|c|}
\hline City & \multicolumn{6}{|c|}{ Boston, MA } \\
\hline Home vintage & $<1950$ & $1950-1969$ & 1970-1989 & 1990-2009 & $\begin{array}{r}2010-2015 \\
(2010-2029)\end{array}$ & $2030-2050$ \\
\hline $\begin{array}{c}\text { Floor Insulation } \\
\left(\mathbf{m}^{2} \mathbf{K} / \mathbf{W}\right)\end{array}$ & Uninsulated & Uninsulated & Uninsulated & $3.7(\mathrm{R}-21)$ & $5.3(\mathrm{R}-30)$ & $6.7(\mathrm{R}-38)$ \\
\hline Exterior Wall Material & Wood, light & Wood, light & Wood, light & Vinyl, light & Vinyl, light & Vinyl, light \\
\hline $\begin{array}{c}\text { Wall insulation } \\
\left(\mathbf{m}^{2} \mathbf{K} / \mathbf{W}\right)\end{array}$ & Uninsulated & Uninsulated & $2.3(\mathrm{R}-13)$ & $3.2(\mathrm{R}-18)$ & $5.8(\mathrm{R}-33)$ & $7.0(\mathrm{R}-40)$ \\
\hline Wall Characteristics & $\begin{array}{c}\text { Fiberglass } \\
\text { batt } \\
\text { Gr-1, } 2 \times 4, \\
16 \text { in o.c. }\end{array}$ & $\begin{array}{c}\text { Fiberglass } \\
\text { batt } \\
\text { Gr- } 1,2 \times 4, \\
16 \text { in o.c. }\end{array}$ & $\begin{array}{c}\text { Fiberglass } \\
\text { batt } \\
\text { Gr- } 1,2 \times 4, \\
16 \text { in o.c. }\end{array}$ & $\begin{array}{c}\text { Fiberglass } \\
\text { batt } \\
\text { Gr- } 1,2 \times 4, \\
16 \text { in o.c. }\end{array}$ & $\begin{array}{c}\text { Fiberglass } \\
\text { batt } \\
\text { Gr- } 1,2 \times 4, \\
16 \text { in o.c. }\end{array}$ & $\begin{array}{c}\text { Fiberglass } \\
\text { batt } \\
\text { Gr- } 1,2 \times 4, \\
16 \text { in o.c. }\end{array}$ \\
\hline $\begin{array}{c}\text { Attic Insulation } \\
\left(\mathbf{m}^{2} \mathbf{K} / \mathbf{W}\right)\end{array}$ & Uninsulated & $3.9(\mathrm{R}-22)$ & $4.8(\mathrm{R}-27)$ & 6.7 (R-38) & $8.6(\mathrm{R}-49)$ & $10.6(\mathrm{R}-60)$ \\
\hline $\begin{array}{c}\text { Window U-Value } \\
\left(\mathbf{W} / \mathbf{m}^{2} \mathbf{K}\right)\end{array}$ & 3.1 & 3.5 & 2.6 & 2.0 & 2.0 & 1.5 \\
\hline Window SHGC & 0.65 & 0.66 & 0.59 & 0.59 & 0.59 & 0.59 \\
\hline $\begin{array}{c}\begin{array}{c}\text { Duct Insulation } \\
\left(\mathbf{m}^{2} \mathbf{K} / \mathbf{W}\right)\end{array} \\
\end{array}$ & $0.7(\mathrm{R}-4)$ & $0.7(\mathrm{R}-4)$ & $0.9(\mathrm{R}-5)$ & $0.9(\mathrm{R}-5)$ & $1.4(\mathrm{R}-8)$ & $1.4(\mathrm{R}-8)$ \\
\hline City & \multicolumn{6}{|c|}{ Buffalo, NY } \\
\hline Home vintage & $<1950$ & $1950-1969$ & 1970-1989 & 1990-2009 & $\begin{array}{c}2010-2015 \\
(2010-2029)\end{array}$ & $2030-2050$ \\
\hline $\begin{array}{c}\text { Floor Insulation } \\
\left(\mathbf{m}^{2} \mathbf{K} / \mathbf{W}\right)\end{array}$ & Uninsulated & Uninsulated & $3.4(\mathrm{R}-19)$ & $3.7(\mathrm{R}-21)$ & $5.3(\mathrm{R}-30)$ & $6.7(\mathrm{R}-38)$ \\
\hline Exterior Wall Material & Wood, light & Wood, light & Wood, light & Vinyl, light & Vinyl, light & Vinyl, light \\
\hline $\begin{array}{c}\text { Wall insulation } \\
\left(\mathbf{m}^{2} \mathbf{K} / \mathbf{W}\right)\end{array}$ & Uninsulated & Uninsulated & $2.3(\mathrm{R}-13)$ & $3.7(\mathrm{R}-21)$ & $5.8(\mathrm{R}-33)$ & $7.0(\mathrm{R}-40)$ \\
\hline Wall Characteristics & $\begin{array}{c}\text { Fiberglass } \\
\text { batt } \\
\text { Gr- } 1,2 \times 4, \\
16 \text { in o.c. }\end{array}$ & $\begin{array}{c}\text { Fiberglass } \\
\text { batt } \\
\text { Gr- } 1,2 \times 4, \\
16 \text { in o.c. }\end{array}$ & $\begin{array}{c}\text { Fiberglass } \\
\text { batt } \\
\text { Gr- } 1,2 \times 4, \\
16 \text { in o.c. }\end{array}$ & $\begin{array}{c}\text { Fiberglass } \\
\text { batt } \\
\text { Gr- } 1,2 \times 4, \\
16 \text { in o.c. }\end{array}$ & $\begin{array}{c}\text { Fiberglass } \\
\text { batt } \\
\text { Gr- } 1,2 \times 4, \\
16 \text { in o.c. }\end{array}$ & $\begin{array}{c}\text { Fiberglass } \\
\text { batt } \\
\text { Gr- } 1,2 \times 4 \text {, } \\
16 \text { in o.c. }\end{array}$ \\
\hline $\begin{array}{c}\text { Attic Insulation } \\
\left(\mathbf{m}^{2} \mathbf{K} / \mathbf{W}\right)\end{array}$ & Uninsulated & $1.2(\mathrm{R}-7)$ & $4.8(\mathrm{R}-27)$ & $8.6(\mathrm{R}-49)$ & 6.7 (R-38) & $10.6(\mathrm{R}-60)$ \\
\hline $\begin{array}{c}\text { Window U-Value } \\
\left(\mathbf{W} / \mathbf{m}^{2} \mathbf{K}\right)\end{array}$ & 3.1 & 3.5 & 2.6 & 2.0 & 1.7 & 1.5 \\
\hline Window SHGC & 0.65 & 0.66 & 0.59 & 0.59 & 0.59 & 0.59 \\
\hline $\begin{array}{c}\text { Duct Insulation } \\
\left(\mathrm{m}^{2} \mathrm{~K} / \mathrm{W}\right)\end{array}$ & $0.7(\mathrm{R}-4)$ & $0.7(\mathrm{R}-4)$ & $0.9(\mathrm{R}-5)$ & $0.9(\mathrm{R}-5)$ & $1.4(\mathrm{R}-8)$ & $1.4(\mathrm{R}-8)$ \\
\hline
\end{tabular}


Table A-5 (continued). Home characteristics by climate zone and year of construction

\begin{tabular}{|c|c|c|c|c|c|c|}
\hline City & \multicolumn{6}{|c|}{ Chicago, IL } \\
\hline Home vintage & $<1950$ & $1950-1969$ & 1970-1989 & 1990-2009 & $\begin{array}{c}2010-2015 \\
(2010-2029) \\
\end{array}$ & $2030-2050$ \\
\hline $\begin{array}{c}\begin{array}{c}\text { Floor Insulation } \\
\left(\mathbf{m}^{2} \mathbf{K} / \mathbf{W}\right)\end{array} \\
\end{array}$ & Uninsulated & Uninsulated & Uninsulated & $3.7(\mathrm{R}-21)$ & $5.3(\mathrm{R}-30)$ & $6.7(\mathrm{R}-38)$ \\
\hline Exterior Wall Material & Wood, light & Brick & Aluminum & Vinyl, light & Vinyl, light & Vinyl, light \\
\hline $\begin{array}{c}\begin{array}{c}\text { Wall insulation } \\
\left(\mathbf{m}^{2} \mathbf{K} / \mathbf{W}\right)\end{array} \\
\end{array}$ & Uninsulated & Uninsulated & $2.3(\mathrm{R}-13)$ & $3.7(\mathrm{R}-21)$ & $5.8(\mathrm{R}-33)$ & $7.0(\mathrm{R}-40)$ \\
\hline Wall Characteristics & $\begin{array}{c}\begin{array}{c}\text { Fiberglass } \\
\text { batt }\end{array} \\
\text { Gr- } 1,2 \times 4, \\
16 \text { in o.c. }\end{array}$ & $\begin{array}{c}\text { Fiberglass } \\
\text { batt } \\
\text { Gr- } 1,2 \times 4, \\
16 \text { in o.c. }\end{array}$ & $\begin{array}{c}\text { Fiberglass } \\
\text { batt } \\
\text { Gr- } 1,2 \times 4, \\
16 \text { in o.c. }\end{array}$ & $\begin{array}{c}\text { Fiberglass } \\
\text { batt } \\
\text { Gr- } 1,2 \times 4, \\
16 \text { in o.c. }\end{array}$ & $\begin{array}{c}\text { Fiberglass } \\
\text { batt } \\
\text { Gr-1, } 2 \times 4, \\
16 \text { in o.c. }\end{array}$ & $\begin{array}{c}\text { Fiberglass } \\
\text { batt } \\
\text { Gr- } 1,2 \times 4, \\
16 \text { in o.c. }\end{array}$ \\
\hline $\begin{array}{c}\text { Attic Insulation } \\
\left(\mathbf{m}^{2} \mathbf{K} / \mathbf{W}\right)\end{array}$ & Uninsulated & $1.9(\mathrm{R}-11)$ & $5.6(\mathrm{R}-32)$ & $8.6(\mathrm{R}-49)$ & $6.7(\mathrm{R}-38)$ & $10.6(\mathrm{R}-60)$ \\
\hline $\begin{array}{c}\text { Window U-Value } \\
\left(\mathbf{W} / \mathbf{m}^{2} \mathbf{K}\right)\end{array}$ & 3.1 & 3.5 & 2.6 & 2.0 & 2.0 & 1.5 \\
\hline Window SHGC & 0.65 & 0.66 & 0.59 & 0.59 & 0.59 & 0.59 \\
\hline $\begin{array}{l}\text { Duct Insulation } \\
\left(\mathrm{m}^{2} \mathrm{~K} / \mathrm{W}\right)\end{array}$ & $0.7(\mathrm{R}-4)$ & $0.7(\mathrm{R}-4)$ & $0.9(\mathrm{R}-5)$ & $0.9(\mathrm{R}-5)$ & $1.4(\mathrm{R}-8)$ & $1.4(\mathrm{R}-8)$ \\
\hline City & \multicolumn{6}{|c|}{ Cincinnati, OH } \\
\hline Home vintage & $<1950$ & $1950-1969$ & 1970-1989 & 1990-2009 & $\begin{array}{c}2010-2015 \\
(2010-2029) \\
\end{array}$ & $2030-2050$ \\
\hline $\begin{array}{c}\begin{array}{c}\text { Floor Insulation } \\
\left(\mathbf{m}^{2} \mathbf{K} / \mathbf{W}\right)\end{array} \\
\end{array}$ & Uninsulated & Uninsulated & Uninsulated & $3.4(\mathrm{R}-19)$ & $3.4(\mathrm{R}-19)$ & $3.7(\mathrm{R}-21)$ \\
\hline Exterior Wall Material & Wood, light & Brick & Aluminum & Vinyl, light & Vinyl, light & Vinyl, light \\
\hline $\begin{array}{c}\text { Wall insulation } \\
\left(\mathbf{m}^{2} \mathbf{K} / \mathbf{W}\right)\end{array}$ & Uninsulated & Uninsulated & $2.3(\mathrm{R}-13)$ & $3.7(\mathrm{R}-21)$ & $5.8(\mathrm{R}-33)$ & $6.3(\mathrm{R}-36)$ \\
\hline Wall Characteristics & $\begin{array}{c}\text { Fiberglass } \\
\text { batt } \\
\text { Gr- } 1,2 \times 4 \\
16 \text { in o.c. }\end{array}$ & $\begin{array}{c}\begin{array}{c}\text { Fiberglass } \\
\text { batt }\end{array} \\
\text { Gr- } 1,2 \times 4, \\
16 \text { in o.c. }\end{array}$ & 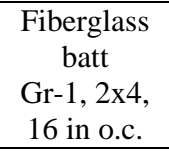 & $\begin{array}{c}\begin{array}{c}\text { Fiberglass } \\
\text { batt }\end{array} \\
\text { Gr-1, } 2 \times 4, \\
16 \text { in o.c. }\end{array}$ & $\begin{array}{c}\begin{array}{c}\text { Fiberglass } \\
\text { batt }\end{array} \\
\text { Gr-1, } 2 \times 4, \\
16 \text { in o.c. }\end{array}$ & $\begin{array}{c}\text { Fiberglass } \\
\text { batt } \\
\text { Gr-1, } 2 \times 4, \\
16 \text { in o.c }\end{array}$ \\
\hline $\begin{array}{c}\text { Attic Insulation } \\
\left(\mathbf{m}^{2} \mathbf{K} / \mathbf{W}\right)\end{array}$ & Uninsulated & $1.9(\mathrm{R}-11)$ & $5.6(\mathrm{R}-32)$ & $6.7(\mathrm{R}-38)$ & $6.7(\mathrm{R}-38)$ & $10.6(\mathrm{R}-60)$ \\
\hline $\begin{array}{c}\text { Window U-Value } \\
\left(\mathbf{W} / \mathbf{m}^{2} \mathbf{K}\right)\end{array}$ & 3.1 & 3.5 & 2.6 & 2.6 & 2.0 & 1.7 \\
\hline Window SHGC & 0.65 & 0.66 & 0.59 & 0.59 & 0.59 & 0.59 \\
\hline $\begin{array}{c}\text { Duct Insulation } \\
\left(\mathbf{m}^{2} \mathbf{K} / \mathbf{W}\right)\end{array}$ & $0.7(\mathrm{R}-4)$ & $0.7(\mathrm{R}-4)$ & $0.9(\mathrm{R}-5)$ & $0.9(\mathrm{R}-5)$ & $1.4(\mathrm{R}-8)$ & $1.4(\mathrm{R}-8)$ \\
\hline
\end{tabular}


Table A-5 (continued). Home characteristics by climate zone and year of construction

\begin{tabular}{|c|c|c|c|c|c|c|}
\hline City & \multicolumn{6}{|c|}{ Corpus Christi, TX } \\
\hline Home vintage & $<1950$ & $1950-1969$ & 1970-1989 & 1990-2009 & $\begin{array}{c}2010-2015 \\
(2010-2029)\end{array}$ & $2030-2050$ \\
\hline $\begin{array}{c}\text { Floor Insulation } \\
\left(\mathrm{m}^{2} \mathrm{~K} / \mathrm{W}\right)\end{array}$ & Uninsulated & Uninsulated & $0.9(\mathrm{R}-5)$ & $1.9(\mathrm{R}-11)$ & $2.3(\mathrm{R}-13)$ & $3.3(\mathrm{R}-19)$ \\
\hline $\begin{array}{c}\text { Exterior Wall } \\
\text { Material }\end{array}$ & Wood, light & Brick & Wood, light & Vinyl, light & Vinyl, light & Vinyl, light \\
\hline $\begin{array}{c}\text { Wall insulation } \\
\left(\mathbf{m}^{2} \mathbf{K} / \mathbf{W}\right)\end{array}$ & Uninsulated & Uninsulated & $1.9(\mathrm{R}-11)$ & $1.9(\mathrm{R}-11)$ & $3.0(\mathrm{R}-17)$ & $3.3(\mathrm{R}-19)$ \\
\hline Wall Characteristics & $\begin{array}{c}\text { Fiberglass } \\
\text { batt } \\
\text { Gr-1, } 2 \times 4, \\
16 \text { in o.c. }\end{array}$ & $\begin{array}{c}\text { Fiberglass } \\
\text { batt } \\
\text { Gr- } 1,2 \times 4, \\
16 \text { in o.c. }\end{array}$ & $\begin{array}{c}\begin{array}{c}\text { Fiberglass } \\
\text { batt }\end{array} \\
\text { Gr- } 1,2 \times 4, \\
16 \text { in o.c. }\end{array}$ & $\begin{array}{c}\text { Fiberglass } \\
\text { batt } \\
\text { Gr-1, } 2 \times 4, \\
16 \text { in o.c. }\end{array}$ & $\begin{array}{c}\text { Fiberglass } \\
\text { batt } \\
\text { Gr- } 1,2 \times 4, \\
16 \text { in o.c. }\end{array}$ & $\begin{array}{c}\text { Fiberglass } \\
\text { batt } \\
\text { Gr-1, } 2 \times 4, \\
16 \text { in o.c. }\end{array}$ \\
\hline $\begin{array}{l}\text { Attic Insulation } \\
\left(\mathbf{m}^{2} \mathrm{~K} / \mathrm{W}\right)\end{array}$ & Uninsulated & $1.2(\mathrm{R}-7)$ & $1.2(\mathrm{R}-7)$ & $3.4(\mathrm{R}-19)$ & $5.3(\mathrm{R}-30)$ & $8.6(\mathrm{R}-49)$ \\
\hline $\begin{array}{c}\text { Window U-Value } \\
\left(\mathbf{W} / \mathbf{m}^{2} \mathbf{K}\right)\end{array}$ & 5.3 & 6.0 & 6.0 & 4.3 & 3.7 & 2.0 \\
\hline Window SHGC & 0.72 & 0.73 & 0.73 & 0.40 & 0.30 & 0.22 \\
\hline $\begin{array}{l}\text { Duct Insulation } \\
\left(\mathbf{m}^{2} \mathrm{~K} / \mathrm{W}\right)\end{array}$ & $0.7(\mathrm{R}-4)$ & $0.7(\mathrm{R}-4)$ & $0.9(\mathrm{R}-5)$ & $0.9(\mathrm{R}-5)$ & $1.4(\mathrm{R}-8)$ & $1.4(\mathrm{R}-8)$ \\
\hline City & \multicolumn{6}{|c|}{ Dallas, $\mathbf{T X}$} \\
\hline Home vintage & $<1950$ & $1950-1969$ & 1970-1989 & $1990-2009$ & $\begin{array}{c}2010-2015 \\
(2010-2029) \\
\end{array}$ & $2030-2050$ \\
\hline $\begin{array}{c}\text { Floor Insulation } \\
\left(\mathbf{m}^{2} \mathrm{~K} / \mathrm{W}\right)\end{array}$ & Uninsulated & Uninsulated & $0.9(\mathrm{R}-5)$ & $1.9(\mathrm{R}-11)$ & $3.4(\mathrm{R}-19)$ & $3.7(\mathrm{R}-21)$ \\
\hline $\begin{array}{c}\text { Exterior Wall } \\
\text { Material }\end{array}$ & Wood, light & Brick & Wood, light & Vinyl, light & Vinyl, light & Vinyl, light \\
\hline $\begin{array}{c}\text { Wall insulation } \\
\left(\mathbf{m}^{2} \mathbf{K} / \mathbf{W}\right)\end{array}$ & Uninsulated & Uninsulated & $1.9(\mathrm{R}-11)$ & $1.9(\mathrm{R}-11)$ & $3.2(\mathrm{R}-18)$ & $6.3(\mathrm{R}-36)$ \\
\hline Wall Characteristics & $\begin{array}{c}\text { Fiberglass } \\
\text { batt } \\
\text { Gr-1, } 2 \times 4, \\
16 \text { in o.c. }\end{array}$ & $\begin{array}{c}\text { Fiberglass } \\
\text { batt } \\
\text { Gr-1, } 2 \times 4, \\
16 \text { in o.c. }\end{array}$ & $\begin{array}{c}\text { Fiberglass } \\
\text { batt } \\
\text { Gr- } 1,2 \times 4, \\
16 \text { in o.c. }\end{array}$ & $\begin{array}{c}\text { Fiberglass } \\
\text { batt } \\
\text { Gr- } 1,2 \times 4 \text {, } \\
16 \text { in o.c. }\end{array}$ & $\begin{array}{c}\text { Fiberglass } \\
\text { batt } \\
\text { Gr- } 1,2 \times 4, \\
16 \text { in o.c. }\end{array}$ & $\begin{array}{c}\text { Fiberglass } \\
\text { batt } \\
\text { Gr-1, } 2 \times 4, \\
16 \text { in o.c. }\end{array}$ \\
\hline $\begin{array}{c}\text { Attic Insulation } \\
\left(\mathbf{m}^{2} \mathbf{K} / \mathbf{W}\right)\end{array}$ & Uninsulated & $1.2(\mathrm{R}-7)$ & 4.8 (R-27) & $3.4(\mathrm{R}-19)$ & $5.3(\mathrm{R}-30)$ & $8.6(\mathrm{R}-49)$ \\
\hline $\begin{array}{c}\text { Window U-Value } \\
\left(W / \mathbf{m}^{2} \mathbf{K}\right)\end{array}$ & 5.3 & 6.0 & 6.0 & 4.3 & 2.8 & 1.7 \\
\hline Window SHGC & 0.72 & 0.73 & 0.73 & 0.4 & 0.3 & 0.22 \\
\hline $\begin{array}{c}\text { Duct Insulation } \\
\left(\mathrm{m}^{2} \mathrm{~K} / \mathrm{W}\right)\end{array}$ & $0.7(\mathrm{R}-4)$ & $0.7(\mathrm{R}-4)$ & $0.9(\mathrm{R}-5)$ & 0.9 (R-5) & $1.4(\mathrm{R}-8)$ & $1.4(\mathrm{R}-8)$ \\
\hline
\end{tabular}


Table A-5 (continued). Home characteristics by climate zone and year of construction

\begin{tabular}{|c|c|c|c|c|c|c|}
\hline City & \multicolumn{6}{|c|}{ Denver, CO } \\
\hline Home vintage & $<1950$ & $1950-1969$ & 1970-1989 & $1990-2009$ & $\begin{array}{c}2010-2015 \\
(2010-2029)\end{array}$ & $2030-2050$ \\
\hline $\begin{array}{c}\text { Floor Insulation } \\
\left(\mathrm{m}^{2} \mathrm{~K} / \mathbf{W}\right)\end{array}$ & Uninsulated & Uninsulated & $0.9(\mathrm{R}-5)$ & $3.7(\mathrm{R}-21)$ & $3.7(\mathrm{R}-21)$ & $6.7(\mathrm{R}-38)$ \\
\hline $\begin{array}{c}\text { Exterior Wall } \\
\text { Material } \\
\end{array}$ & Wood, light & Brick & stucco & Vinyl, light & Vinyl, light & Vinyl, light \\
\hline $\begin{array}{c}\text { Wall insulation } \\
\left(\mathrm{m}^{2} \mathbf{K} / \mathbf{W}\right)\end{array}$ & Uninsulated & Uninsulated & $2.3(\mathrm{R}-13)$ & $3.2(\mathrm{R}-18)$ & $3.2(\mathrm{R}-18)$ & $7.0(\mathrm{R}-40)$ \\
\hline $\begin{array}{c}\text { Wall } \\
\text { Characteristics }\end{array}$ & $\begin{array}{c}\text { Fiberglass } \\
\text { batt } \\
\text { Gr- } 1,2 \times 4, \\
16 \text { in o.c. }\end{array}$ & $\begin{array}{c}\text { Fiberglass } \\
\text { batt } \\
\text { Gr- } 1,2 \times 4, \\
16 \text { in o.c. }\end{array}$ & $\begin{array}{c}\text { Fiberglass } \\
\text { batt } \\
\text { Gr- } 1,2 \times 4, \\
16 \text { in o.c. }\end{array}$ & $\begin{array}{c}\text { Fiberglass } \\
\text { batt } \\
\text { Gr- } 1,2 \times 4, \\
16 \text { in o.c. }\end{array}$ & $\begin{array}{c}\text { Fiberglass } \\
\text { batt } \\
\text { Gr-1, } 2 \times 4, \\
16 \text { in o.c. }\end{array}$ & $\begin{array}{c}\text { Fiberglass } \\
\text { batt } \\
\text { Gr-1, } 2 \times 4, \\
16 \text { in o.c. }\end{array}$ \\
\hline $\begin{array}{l}\text { Attic Insulation } \\
\qquad\left(\mathbf{m}^{2} \mathbf{K} / \mathbf{W}\right)\end{array}$ & Uninsulated & $1.9(\mathrm{R}-11)$ & $5.1(\mathrm{R}-29)$ & $6.7(\mathrm{R}-38)$ & $6.7(\mathrm{R}-38)$ & $10.6(\mathrm{R}-60)$ \\
\hline $\begin{array}{c}\text { Window U-Value } \\
\left(W / \mathbf{m}^{2} \mathbf{K}\right)\end{array}$ & 5.3 & 6.0 & 2.6 & 2.0 & 2.0 & 1.5 \\
\hline Window SHGC & 0.72 & 0.73 & 0.59 & 0.59 & 0.59 & 0.59 \\
\hline $\begin{array}{l}\text { Duct Insulation } \\
\qquad\left(\mathrm{m}^{2} \mathrm{~K} / \mathbf{W}\right)\end{array}$ & $0.7(\mathrm{R}-4)$ & $0.7(\mathrm{R}-4)$ & $0.9(\mathrm{R}-5)$ & $0.9(\mathrm{R}-5)$ & $1.4(\mathrm{R}-8)$ & $1.4(\mathrm{R}-8)$ \\
\hline City & \multicolumn{6}{|c|}{ Los Angeles, CA } \\
\hline Home vintage & $<1950$ & $1950-1969$ & 1970-1989 & $1990-2009$ & $\begin{array}{c}2010-2015 \\
(2010-2029) \\
\end{array}$ & $2030-2050$ \\
\hline $\begin{array}{c}\text { Floor Insulation } \\
\left(\mathrm{m}^{2} \mathrm{~K} / \mathrm{W}\right)\end{array}$ & Uninsulated & Uninsulated & Uninsulated & $3.4(\mathrm{R}-19)$ & $3.4(\mathrm{R}-19)$ & $3.7(\mathrm{R}-21)$ \\
\hline $\begin{array}{c}\text { Exterior Wall } \\
\text { Material }\end{array}$ & Wood, light & stucco & stucco & Vinyl, light & Vinyl, light & Vinyl, light \\
\hline $\begin{array}{c}\text { Wall insulation } \\
\left(\mathbf{m}^{2} \mathbf{K} / \mathbf{W}\right)\end{array}$ & Uninsulated & Uninsulated & $1.9(\mathrm{R}-11)$ & $2.3(\mathrm{R}-13)$ & $3.2(\mathrm{R}-18)$ & $6.3(\mathrm{R}-36)$ \\
\hline $\begin{array}{c}\text { Wall } \\
\text { Characteristics }\end{array}$ & $\begin{array}{c}\text { Fiberglass } \\
\text { batt } \\
\text { Gr- } 1,2 \times 4, \\
16 \text { in o.c. }\end{array}$ & $\begin{array}{c}\text { Fiberglass } \\
\text { batt } \\
\text { Gr- } 1,2 \times 4, \\
16 \text { in o.c. }\end{array}$ & $\begin{array}{c}\text { Fiberglass } \\
\text { batt } \\
\text { Gr- } 1,2 \times 4, \\
16 \text { in o.c. }\end{array}$ & $\begin{array}{c}\text { Fiberglass } \\
\text { batt } \\
\text { Gr- } 1,2 \times 4, \\
16 \text { in o.c. }\end{array}$ & $\begin{array}{c}\text { Fiberglass } \\
\text { batt } \\
\text { Gr- } 1,2 \times 4, \\
16 \text { in o.c. }\end{array}$ & $\begin{array}{c}\text { Fiberglass } \\
\text { batt } \\
\text { Gr-1, } 2 \times 4, \\
16 \text { in o.c. }\end{array}$ \\
\hline $\begin{array}{c}\text { Attic Insulation } \\
\left(\mathbf{m}^{2} \mathbf{K} / \mathbf{W}\right)\end{array}$ & Uninsulated & $1.2(\mathrm{R}-7)$ & $4.4(\mathrm{R}-25)$ & $5.3(\mathrm{R}-30)$ & $5.3(\mathrm{R}-30)$ & $8.6(\mathrm{R}-49)$ \\
\hline $\begin{array}{c}\text { Window U-Value } \\
\left(\mathbf{W} / \mathbf{m}^{2} \mathbf{K}\right)\end{array}$ & 5.3 & 6.0 & 3.4 & 3.4 & 2.8 & 1.7 \\
\hline Window SHGC & 0.72 & 0.73 & 0.65 & 0.4 & 0.3 & 0.22 \\
\hline $\begin{array}{c}\begin{array}{c}\text { Duct Insulation } \\
\left(\mathrm{m}^{2} \mathrm{~K} / \mathrm{W}\right)\end{array} \\
\end{array}$ & $0.7(\mathrm{R}-4)$ & $0.7(\mathrm{R}-4)$ & $0.9(\mathrm{R}-5)$ & $0.9(\mathrm{R}-5)$ & $1.4(\mathrm{R}-8)$ & $1.4(\mathrm{R}-8)$ \\
\hline
\end{tabular}


Table A-5 (continued). Home characteristics by climate zone and year of construction

\begin{tabular}{|c|c|c|c|c|c|c|}
\hline City & \multicolumn{6}{|c|}{ Miami, FL } \\
\hline Home vintage & $<1950$ & $1950-1969$ & 1970-1989 & $1990-2009$ & $\begin{array}{c}2010-2015 \\
(2010-2029) \\
\end{array}$ & $2030-2050$ \\
\hline $\begin{array}{c}\text { Floor Insulation } \\
\left(\mathbf{m}^{2} \mathbf{K} / \mathbf{W}\right)\end{array}$ & Uninsulated & Uninsulated & $3.4(\mathrm{R}-19)$ & $1.9(\mathrm{R}-11)$ & $2.3(\mathrm{R}-13)$ & $3.4(\mathrm{R}-19)$ \\
\hline Exterior Wall Material & Wood, light & Brick & Aluminum & Vinyl, light & Vinyl, light & Vinyl, light \\
\hline $\begin{array}{c}\text { Wall insulation } \\
\left(\mathbf{m}^{2} \mathbf{K} / \mathbf{W}\right)\end{array}$ & Uninsulated & Uninsulated & $1.9(\mathrm{R}-11)$ & $1.9(\mathrm{R}-11)$ & $2.8(\mathrm{R}-16)$ & $4.1(\mathrm{R}-23)$ \\
\hline Wall Characteristics & $\begin{array}{c}\begin{array}{c}\text { Fiberglass } \\
\text { batt }\end{array} \\
\text { Gr- } 1,2 \times 4, \\
16 \text { in o.c. }\end{array}$ & $\begin{array}{c}\begin{array}{c}\text { Fiberglass } \\
\text { batt }\end{array} \\
\text { Gr- } 1,2 \times 4, \\
16 \text { in o.c. }\end{array}$ & $\begin{array}{c}\text { Fiberglass } \\
\text { batt } \\
\text { Gr- } 1,2 \times 4, \\
16 \text { in o.c. }\end{array}$ & $\begin{array}{c}\begin{array}{c}\text { Fiberglass } \\
\text { batt }\end{array} \\
\text { Gr-1, } 2 \times 4, \\
16 \text { in o.c. }\end{array}$ & $\begin{array}{c}\text { Fiberglass } \\
\text { batt } \\
\text { Gr- } 1,2 \times 4, \\
16 \text { in o.c. }\end{array}$ & $\begin{array}{c}\text { Fiberglass } \\
\text { batt } \\
\text { Gr- } 1,2 \times 4, \\
16 \text { in o.c. }\end{array}$ \\
\hline $\begin{array}{l}\text { Attic Insulation } \\
\left(\mathbf{m}^{2} \mathbf{K} / \mathbf{W}\right)\end{array}$ & Uninsulated & $1.2(\mathrm{R}-7)$ & $4.8(\mathrm{R}-27)$ & $2.3(\mathrm{R}-13)$ & $5.3(\mathrm{R}-30)$ & $6.7(\mathrm{R}-38)$ \\
\hline $\begin{array}{c}\text { Window U-Value } \\
\left(\mathbf{W} / \mathbf{m}^{2} \mathbf{K}\right)\end{array}$ & 3.1 & 3.5 & 6.0 & 6.9 & 6.8 & 1.8 \\
\hline Window SHGC & 0.65 & 0.66 & 0.73 & 0.40 & 0.30 & 0.22 \\
\hline $\begin{array}{l}\text { Duct Insulation } \\
\left(\mathrm{m}^{2} \mathrm{~K} / \mathrm{W}\right)\end{array}$ & $0.7(\mathrm{R}-4)$ & $0.7(\mathrm{R}-4)$ & $0.9(\mathrm{R}-5)$ & $0.9(\mathrm{R}-5)$ & $1.4(\mathrm{R}-8)$ & $1.4(\mathrm{R}-8)$ \\
\hline City & \multicolumn{6}{|c|}{ Minneapolis, MN } \\
\hline Home vintage & $<1950$ & $1950-1969$ & 1970-1989 & 1990-2009 & $\begin{array}{c}2010-2015 \\
(2010-2029) \\
\end{array}$ & $2030-2050$ \\
\hline $\begin{array}{c}\text { Floor Insulation } \\
\left(\mathbf{m}^{2} \mathbf{K} / \mathbf{W}\right)\end{array}$ & Uninsulated & Uninsulated & $0.9(\mathrm{R}-5)$ & $3.7(\mathrm{R}-21)$ & $5.3(\mathrm{R}-30)$ & $8.6(\mathrm{R}-49)$ \\
\hline Exterior Wall Material & Wood, light & Wood, light & Wood, light & Vinyl, light & Vinyl, light & Vinyl, light \\
\hline $\begin{array}{c}\text { Wall insulation } \\
\left(\mathrm{m}^{2} \mathrm{~K} / \mathbf{W}\right)\end{array}$ & Uninsulated & Uninsulated & $3.4(\mathrm{R}-19)$ & $3.7(\mathrm{R}-21)$ & $6.0(\mathrm{R}-34)$ & $9.0(\mathrm{R}-51)$ \\
\hline Wall Characteristics & $\begin{array}{c}\text { Fiberglass } \\
\text { batt } \\
\text { Gr- } 1,2 \times 4, \\
16 \text { in o.c. }\end{array}$ & $\begin{array}{c}\text { Fiberglass } \\
\text { batt } \\
\text { Gr- } 1,2 \times 4, \\
16 \text { in o.c. }\end{array}$ & $\begin{array}{c}\text { Fiberglass } \\
\text { batt } \\
\text { Gr- } 1,2 \times 4, \\
16 \text { in o.c. }\end{array}$ & $\begin{array}{c}\text { Fiberglass } \\
\text { batt } \\
\text { Gr-1, } 2 \times 4, \\
16 \text { in o.c. }\end{array}$ & $\begin{array}{c}\text { Fiberglass } \\
\text { batt } \\
\text { Gr- } 1,2 \times 4, \\
16 \text { in o.c. }\end{array}$ & $\begin{array}{c}\text { Fiberglass } \\
\text { batt } \\
\text { Gr-1, } 2 \times 4 \\
16 \text { in o.c. }\end{array}$ \\
\hline $\begin{array}{c}\begin{array}{c}\text { Attic Insulation } \\
\left(\mathbf{m}^{2} \mathbf{K} / \mathbf{W}\right)\end{array} \\
\end{array}$ & Uninsulated & $1.2(\mathrm{R}-7)$ & $5.6(\mathrm{R}-32)$ & $8.6(\mathrm{R}-49)$ & $8.6(\mathrm{R}-49)$ & $10.6(\mathrm{R}-60)$ \\
\hline $\begin{array}{c}\text { Window U-Value } \\
\left(\mathbf{W} / \mathbf{m}^{2} \mathbf{K}\right)\end{array}$ & 3.1 & 3.5 & 2.6 & 2.0 & 2.0 & 1.5 \\
\hline Window SHGC & 0.65 & 0.65 & 0.59 & 0.59 & 0.59 & 0.59 \\
\hline $\begin{array}{c}\text { Duct Insulation } \\
\left(\mathbf{m}^{2} \mathrm{~K} / \mathrm{W}\right)\end{array}$ & $0.7(\mathrm{R}-4)$ & $0.7(\mathrm{R}-4)$ & $0.9(\mathrm{R}-5)$ & $0.9(\mathrm{R}-5)$ & $1.4(\mathrm{R}-8)$ & $1.4(\mathrm{R}-8)$ \\
\hline
\end{tabular}


Table A-5 (continued). Home characteristics by climate zone and year of construction

\begin{tabular}{|c|c|c|c|c|c|c|}
\hline City & \multicolumn{6}{|c|}{ Nashville, TN } \\
\hline Home vintage & $<1950$ & $1950-1969$ & 1970-1989 & 1990-2009 & $\begin{array}{c}2010-2015 \\
(2010-2029)\end{array}$ & $2030-2050$ \\
\hline $\begin{array}{c}\text { Floor Insulation } \\
\left(\mathbf{m}^{2} \mathbf{K} / \mathbf{W}\right)\end{array}$ & Uninsulated & Uninsulated & Uninsulated & $3.4(\mathrm{R}-19)$ & $3.4(\mathrm{R}-19)$ & $3.7(\mathrm{R}-21)$ \\
\hline Exterior Wall Material & Wood, light & Brick & Aluminum & Vinyl, light & Vinyl, light & Vinyl, light \\
\hline $\begin{array}{c}\text { Wall insulation } \\
\left(\mathrm{m}^{2} \mathrm{~K} / \mathrm{W}\right)\end{array}$ & Uninsulated & Uninsulated & $1.9(\mathrm{R}-11)$ & $2.3(\mathrm{R}-13)$ & $3.2(\mathrm{R}-18)$ & $6.3(\mathrm{R}-36)$ \\
\hline Wall Characteristics & $\begin{array}{c}\text { Fiberglass } \\
\text { batt } \\
\text { Gr- } 1,2 \times 4, \\
16 \text { in o.c. }\end{array}$ & $\begin{array}{c}\begin{array}{c}\text { Fiberglass } \\
\text { batt }\end{array} \\
\text { Gr- } 1,2 \times 4, \\
16 \text { in o.c. }\end{array}$ & $\begin{array}{c}\text { Fiberglass } \\
\text { batt } \\
\text { Gr- } 1,2 \times 4, \\
16 \text { in o.c. }\end{array}$ & $\begin{array}{c}\begin{array}{c}\text { Fiberglass } \\
\text { batt }\end{array} \\
\text { Gr- } 1,2 \times 4, \\
16 \text { in o.c. }\end{array}$ & $\begin{array}{c}\text { Fiberglass } \\
\text { batt } \\
\text { Gr-1, } 2 \times 4, \\
16 \text { in o.c. }\end{array}$ & $\begin{array}{c}\text { Fiberglass } \\
\text { batt } \\
\text { Gr-1, } 2 \times 4 \\
16 \text { in o.c. }\end{array}$ \\
\hline $\begin{array}{l}\text { Attic Insulation } \\
\left(\mathrm{m}^{2} \mathrm{~K} / \mathrm{W}\right)\end{array}$ & Uninsulated & $1.2(\mathrm{R}-7)$ & $4.8(\mathrm{R}-27)$ & $5.3(\mathrm{R}-30)$ & $6.7(\mathrm{R}-38)$ & $10.6(\mathrm{R}-60)$ \\
\hline $\begin{array}{l}\text { Window U-Value } \\
\left(\mathbf{W} / \mathbf{m}^{2} \mathbf{K}\right)\end{array}$ & 5.3 & 6.0 & 3.4 & 2.8 & 2.3 & 1.7 \\
\hline Window SHGC & 0.72 & 0.73 & 0.65 & 0.65 & 0.65 & 0.65 \\
\hline $\begin{array}{l}\text { Duct Insulation } \\
\left(\mathrm{m}^{2} \mathrm{~K} / \mathrm{W}\right)\end{array}$ & $0.7(\mathrm{R}-4)$ & $0.7(\mathrm{R}-4)$ & $0.9(\mathrm{R}-5)$ & $0.9(\mathrm{R}-5)$ & $1.4(\mathrm{R}-8)$ & $1.4(\mathrm{R}-8)$ \\
\hline City & \multicolumn{6}{|c|}{ New York, NY } \\
\hline Home vintage & $<1950$ & $1950-1969$ & 1970-1989 & 1990-2009 & $\begin{array}{c}2010-2015 \\
(2010-2029) \\
\end{array}$ & $2030-2050$ \\
\hline $\begin{array}{c}\begin{array}{c}\text { Floor Insulation } \\
\left(\mathbf{m}^{2} \mathbf{K} / \mathbf{W}\right)\end{array} \\
\end{array}$ & Uninsulated & Uninsulated & $3.4(\mathrm{R}-19)$ & $3.4(\mathrm{R}-19)$ & $3.4(\mathrm{R}-19)$ & $3.7(\mathrm{R}-21)$ \\
\hline Exterior Wall Material & Wood, light & Wood, light & Wood, light & Vinyl, light & Vinyl, light & Vinyl, light \\
\hline $\begin{array}{c}\text { Wall insulation } \\
\left(\mathbf{m}^{2} \mathbf{K} / \mathbf{W}\right)\end{array}$ & Uninsulated & Uninsulated & $2.3(\mathrm{R}-13)$ & $2.8(\mathrm{R}-16)$ & $3.2(\mathrm{R}-18)$ & $6.3(\mathrm{R}-36)$ \\
\hline Wall Characteristics & $\begin{array}{c}\text { Fiberglass } \\
\text { batt } \\
\text { Gr- } 1,2 \times 4 \\
16 \text { in o.c. }\end{array}$ & $\begin{array}{c}\text { Fiberglass } \\
\text { batt } \\
\text { Gr- } 1,2 \times 4, \\
16 \text { in o.c. }\end{array}$ & $\begin{array}{c}\text { Fiberglass } \\
\text { batt } \\
\text { Gr- } 1,2 \times 4, \\
16 \text { in o.c. }\end{array}$ & $\begin{array}{c}\text { Fiberglass } \\
\text { batt } \\
\text { Gr- } 1,2 \times 4, \\
16 \text { in o.c. }\end{array}$ & $\begin{array}{c}\text { Fiberglass } \\
\text { batt } \\
\text { Gr- } 1,2 \times 4, \\
16 \text { in o.c. }\end{array}$ & $\begin{array}{c}\text { Fiberglass } \\
\text { batt } \\
\text { Gr-1, } 2 \times 4 \\
16 \text { in o.c. }\end{array}$ \\
\hline $\begin{array}{c}\text { Attic Insulation } \\
\left(\mathbf{m}^{2} \mathbf{K} / \mathbf{W}\right)\end{array}$ & Uninsulated & $1.2(\mathrm{R}-7)$ & $4.8(\mathrm{R}-27)$ & $6.7(\mathrm{R}-38)$ & $6.7(\mathrm{R}-38)$ & $10.6(\mathrm{R}-60)$ \\
\hline $\begin{array}{c}\text { Window U-Value } \\
\left(\mathbf{W} / \mathbf{m}^{2} \mathbf{K}\right)\end{array}$ & 3.1 & 3.5 & 2.6 & 2.6 & 2.0 & 1.7 \\
\hline Window SHGC & 0.65 & 0.66 & 0.59 & 0.59 & 0.59 & 0.59 \\
\hline $\begin{array}{c}\text { Duct Insulation } \\
\left(\mathrm{m}^{2} \mathrm{~K} / \mathrm{W}\right)\end{array}$ & 0.7 (R-4) & $0.7(\mathrm{R}-4)$ & $0.9(\mathrm{R}-5)$ & $0.9(\mathrm{R}-5)$ & $1.4(\mathrm{R}-8)$ & $1.4(\mathrm{R}-8)$ \\
\hline
\end{tabular}


Table A-5 (continued). Home characteristics by climate zone and year of construction

\begin{tabular}{|c|c|c|c|c|c|c|}
\hline City & \multicolumn{6}{|c|}{ Phoenix, AZ } \\
\hline Home vintage & $<1950$ & $1950-1969$ & 1970-1989 & $1990-2009$ & $\begin{array}{c}2010-2015 \\
(2010-2029) \\
\end{array}$ & $2030-2050$ \\
\hline $\begin{array}{c}\text { Floor Insulation } \\
\left(\mathbf{m}^{2} \mathbf{K} / \mathbf{W}\right)\end{array}$ & Uninsulated & Uninsulated & $0.9(\mathrm{R}-5)$ & $1.9(\mathrm{R}-11)$ & $1.9(\mathrm{R}-11)$ & $3.3(\mathrm{R}-19)$ \\
\hline Exterior Wall Material & Wood, light & Brick & Stucco & Vinyl, light & Vinyl, light & Vinyl, light \\
\hline $\begin{array}{c}\text { Wall insulation } \\
\left(\mathbf{m}^{2} \mathbf{K} / \mathbf{W}\right)\end{array}$ & Uninsulated & Uninsulated & $2.3(\mathrm{R}-13)$ & $1.9(\mathrm{R}-11)$ & $1.9(\mathrm{R}-11)$ & $4.2(\mathrm{R}-24)$ \\
\hline Wall Characteristics & $\begin{array}{c}\begin{array}{c}\text { Fiberglass } \\
\text { batt }\end{array} \\
\text { Gr- } 1,2 \times 4, \\
16 \text { in o.c. }\end{array}$ & $\begin{array}{c}\text { Fiberglass } \\
\text { batt } \\
\text { Gr- } 1,2 \times 4, \\
16 \text { in o.c. }\end{array}$ & $\begin{array}{c}\text { Fiberglass } \\
\text { batt } \\
\text { Gr- } 1,2 \times 4, \\
16 \text { in o.c. }\end{array}$ & $\begin{array}{c}\text { Fiberglass } \\
\text { batt } \\
\text { Gr-1, } 2 \times 4, \\
16 \text { in o.c. }\end{array}$ & $\begin{array}{c}\text { Fiberglass } \\
\text { batt } \\
\text { Gr- } 1,2 \times 4 \text {, } \\
16 \text { in o.c. }\end{array}$ & $\begin{array}{c}\text { Fiberglass } \\
\text { batt } \\
\text { Gr-1, } 2 \times 4, \\
16 \text { in o.c. }\end{array}$ \\
\hline $\begin{array}{l}\text { Attic Insulation } \\
\left(\mathbf{m}^{2} \mathbf{K} / \mathbf{W}\right)\end{array}$ & Uninsulated & $1.9(\mathrm{R}-11)$ & $5.1(\mathrm{R}-29)$ & $3.4(\mathrm{R}-19)$ & $3.4(\mathrm{R}-19)$ & $8.6(\mathrm{R}-49)$ \\
\hline $\begin{array}{c}\text { Window U-Value } \\
\left(\mathbf{W} / \mathbf{m}^{2} \mathbf{K}\right)\end{array}$ & 5.3 & 6.0 & 3.5 & 4.3 & 4.3 & 2.0 \\
\hline Window SHGC & 0.72 & 0.73 & 0.66 & 0.40 & 0.30 & 0.22 \\
\hline $\begin{array}{l}\text { Duct Insulation } \\
\left(\mathrm{m}^{2} \mathrm{~K} / \mathrm{W}\right)\end{array}$ & $0.7(\mathrm{R}-4)$ & $0.7(\mathrm{R}-4)$ & $0.9(\mathrm{R}-5)$ & $0.9(\mathrm{R}-5)$ & $1.4(\mathrm{R}-8)$ & $1.4(\mathrm{R}-8)$ \\
\hline City & \multicolumn{6}{|c|}{ Seattle, WA } \\
\hline Home vintage & $<1950$ & $1950-1969$ & 1970-1989 & $1990-2009$ & $\begin{array}{l}2010-2015 \\
(2010-2029) \\
\end{array}$ & $2030-2050$ \\
\hline $\begin{array}{c}\begin{array}{c}\text { Floor Insulation } \\
\left(\mathbf{m}^{2} \mathbf{K} / \mathbf{W}\right)\end{array} \\
\end{array}$ & Uninsulated & Uninsulated & $3.4(\mathrm{R}-19)$ & $3.4(\mathrm{R}-19)$ & $5.3(\mathrm{R}-30)$ & $6.7(\mathrm{R}-38)$ \\
\hline Exterior Wall Material & Wood, light & Wood, light & Wood, light & Vinyl, light & Vinyl, light & Vinyl, light \\
\hline $\begin{array}{c}\text { Wall insulation } \\
\left(\mathrm{m}^{2} \mathrm{~K} / \mathrm{W}\right)\end{array}$ & Uninsulated & Uninsulated & $1.9(\mathrm{R}-11)$ & $2.8(\mathrm{R}-16)$ & $5.8(\mathrm{R}-33)$ & $7.0(\mathrm{R}-40)$ \\
\hline Wall Characteristics & $\begin{array}{c}\text { Fiberglass } \\
\text { batt } \\
\text { Gr-1, } 2 \times 4, \\
16 \text { in o.c. }\end{array}$ & $\begin{array}{c}\text { Fiberglass } \\
\text { batt } \\
\text { Gr- } 1,2 \times 4, \\
16 \text { in o.c. }\end{array}$ & $\begin{array}{c}\text { Fiberglass } \\
\text { batt } \\
\text { Gr- } 1,2 \times 4, \\
16 \text { in o.c. }\end{array}$ & $\begin{array}{c}\text { Fiberglass } \\
\text { batt } \\
\text { Gr- } 1,2 \times 4, \\
16 \text { in o.c. }\end{array}$ & $\begin{array}{c}\text { Fiberglass } \\
\text { batt } \\
\text { Gr-1, } 2 \times 4, \\
16 \text { in o.c. }\end{array}$ & $\begin{array}{c}\text { Fiberglass } \\
\text { batt } \\
\text { Gr-1, } 2 \times 4, \\
16 \text { in o.c. }\end{array}$ \\
\hline $\begin{array}{c}\text { Attic Insulation } \\
\left(\mathbf{m}^{2} \mathbf{K} / \mathbf{W}\right)\end{array}$ & Uninsulated & $1.9(\mathrm{R}-11)$ & $5.6(\mathrm{R}-32)$ & 6.7 (R-38) & $6.7(\mathrm{R}-38)$ & $10.6(\mathrm{R}-60)$ \\
\hline $\begin{array}{c}\text { Window U-Value } \\
\left(\mathbf{W} / \mathbf{m}^{2} \mathbf{K}\right)\end{array}$ & 3.1 & 3.5 & 2.6 & 2.6 & 2.0 & 1.5 \\
\hline Window SHGC & 0.65 & 0.66 & 0.59 & 0.59 & 0.59 & 0.59 \\
\hline $\begin{array}{c}\text { Duct Insulation } \\
\left(\mathrm{m}^{2} \mathrm{~K} / \mathrm{W}\right)\end{array}$ & $0.7(\mathrm{R}-4)$ & $0.7(\mathrm{R}-4)$ & $0.9(\mathrm{R}-5)$ & $0.9(\mathrm{R}-5)$ & $1.4(\mathrm{R}-8)$ & $1.4(\mathrm{R}-8)$ \\
\hline
\end{tabular}


Table A-5 (continued). Home characteristics by climate zone and year of construction

\begin{tabular}{|c|c|c|c|c|c|c|}
\hline City & \multicolumn{6}{|c|}{$\begin{array}{l}\text { St. Louis, MO } \\
\end{array}$} \\
\hline Home vintage & $<1950$ & $1950-1969$ & 1970-1989 & 1990-2009 & $\begin{array}{c}2010-2015 \\
(2010-2029) \\
\end{array}$ & $2030-2050$ \\
\hline $\begin{array}{c}\text { Floor Insulation } \\
\left(\mathbf{m}^{2} \mathbf{K} / \mathbf{W}\right)\end{array}$ & Uninsulated & Uninsulated & $0.9(\mathrm{R}-5)$ & $3.4(\mathrm{R}-19)$ & $3.4(\mathrm{R}-19)$ & $3.7(\mathrm{R}-21)$ \\
\hline Exterior Wall Material & Wood, light & Wood, light & Wood, light & Vinyl, light & Vinyl, light & Vinyl, light \\
\hline $\begin{array}{c}\text { Wall insulation } \\
\left(\mathbf{m}^{2} \mathbf{K} / \mathbf{W}\right)\end{array}$ & Uninsulated & Uninsulated & $3.4(\mathrm{R}-19)$ & $2.8(\mathrm{R}-16)$ & $2.3(\mathrm{R}-13)$ & $6.3(\mathrm{R}-36)$ \\
\hline Wall Characteristics & $\begin{array}{c}\begin{array}{c}\text { Fiberglass } \\
\text { batt }\end{array} \\
\text { Gr- } 1,2 \times 4, \\
16 \text { in o.c. }\end{array}$ & $\begin{array}{c}\text { Fiberglass } \\
\text { batt } \\
\text { Gr- } 1,2 \times 4, \\
16 \text { in o.c. }\end{array}$ & $\begin{array}{c}\begin{array}{c}\text { Fiberglass } \\
\text { batt }\end{array} \\
\text { Gr- } 1,2 \times 4, \\
16 \text { in o.c. }\end{array}$ & $\begin{array}{c}\begin{array}{c}\text { Fiberglass } \\
\text { batt }\end{array} \\
\text { Gr- } 1,2 \times 4, \\
16 \text { in o.c. }\end{array}$ & $\begin{array}{c}\begin{array}{c}\text { Fiberglass } \\
\text { batt }\end{array} \\
\text { Gr-1, } 2 \times 4, \\
16 \text { in o.c. }\end{array}$ & $\begin{array}{c}\text { Fiberglass } \\
\text { batt } \\
\text { Gr-1, } 2 \times 4, \\
16 \text { in o.c. }\end{array}$ \\
\hline $\begin{array}{l}\text { Attic Insulation } \\
\left(\mathrm{m}^{2} \mathrm{~K} / \mathrm{W}\right)\end{array}$ & Uninsulated & $1.3(\mathrm{R}-7)$ & $5.6(\mathrm{R}-32)$ & $6.7(\mathrm{R}-38)$ & $6.7(\mathrm{R}-38)$ & $10.6(\mathrm{R}-60)$ \\
\hline $\begin{array}{c}\text { Window U-Value } \\
\left(\mathbf{W} / \mathbf{m}^{2} \mathbf{K}\right)\end{array}$ & 3.1 & 3.5 & 2.6 & 2.6 & 2.6 & 1.7 \\
\hline Window SHGC & 0.65 & 0.66 & 0.59 & 0.59 & 0.59 & 0.59 \\
\hline $\begin{array}{l}\text { Duct Insulation } \\
\left(\mathrm{m}^{2} \mathrm{~K} / \mathrm{W}\right)\end{array}$ & $0.7(\mathrm{R}-4)$ & $0.7(\mathrm{R}-4)$ & $0.9(\mathrm{R}-5)$ & $0.9(\mathrm{R}-5)$ & $1.4(\mathrm{R}-8)$ & $1.4(\mathrm{R}-8)$ \\
\hline City & \multicolumn{6}{|c|}{ Washington, DC } \\
\hline Home vintage & $<1950$ & $1950-1969$ & 1970-1989 & 1990-2009 & $\begin{array}{c}2010-2015 \\
(2010-2029) \\
\end{array}$ & $2030-2050$ \\
\hline $\begin{array}{c}\text { Floor Insulation } \\
\left(\mathbf{m}^{2} \mathbf{K} / \mathbf{W}\right)\end{array}$ & Uninsulated & Uninsulated & $3.4(\mathrm{R}-19)$ & $3.4(\mathrm{R}-19)$ & $3.4(\mathrm{R}-19)$ & $3.7(\mathrm{R}-19)$ \\
\hline Exterior Wall Material & Wood, light & Brick & Aluminum & Vinyl, light & Vinyl, light & Vinyl, light \\
\hline $\begin{array}{c}\text { Wall insulation } \\
\left(\mathbf{m}^{2} \mathbf{K} / \mathbf{W}\right)\end{array}$ & Uninsulated & Uninsulated & $1.9(\mathrm{R}-11)$ & $2.8(\mathrm{R}-16)$ & $3.2(\mathrm{R}-18)$ & $6.3(\mathrm{R}-36)$ \\
\hline Wall Characteristics & $\begin{array}{c}\text { Fiberglass } \\
\text { batt } \\
\text { Gr- } 1,2 \times 4, \\
16 \text { in o.c. }\end{array}$ & $\begin{array}{c}\text { Fiberglass } \\
\text { batt } \\
\text { Gr- } 1,2 \times 4, \\
16 \text { in o.c. }\end{array}$ & $\begin{array}{c}\begin{array}{c}\text { Fiberglass } \\
\text { batt }\end{array} \\
\text { Gr- } 1,2 \times 4, \\
16 \text { in o.c. }\end{array}$ & $\begin{array}{c}\text { Fiberglass } \\
\text { batt } \\
\text { Gr- } 1,2 \times 4, \\
16 \text { in o.c. }\end{array}$ & $\begin{array}{c}\text { Fiberglass } \\
\text { batt } \\
\text { Gr- } 1,2 \times 4, \\
16 \text { in o.c. }\end{array}$ & $\begin{array}{c}\text { Fiberglass } \\
\text { batt } \\
\text { Gr-1, } 2 \times 4, \\
16 \text { in o.c. }\end{array}$ \\
\hline $\begin{array}{c}\text { Attic Insulation } \\
\left(\mathbf{m}^{2} \mathbf{K} / \mathbf{W}\right)\end{array}$ & Uninsulated & $1.3(\mathrm{R}-7)$ & $4.8(\mathrm{R}-27)$ & $6.7(\mathrm{R}-38)$ & $6.7(\mathrm{R}-38)$ & $10.6(\mathrm{R}-60)$ \\
\hline $\begin{array}{c}\text { Window U-Value } \\
\left(\mathbf{W} / \mathbf{m}^{2} \mathbf{K}\right)\end{array}$ & 5.3 & 6.0 & 2.6 & 2.6 & 2.0 & 1.7 \\
\hline Window SHGC & 0.72 & 0.73 & 0.59 & 0.59 & 0.59 & 0.59 \\
\hline $\begin{array}{c}\text { Duct Insulation } \\
\left(\mathrm{m}^{2} \mathrm{~K} / \mathrm{W}\right)\end{array}$ & $0.7(\mathrm{R}-4)$ & $0.7(\mathrm{R}-4)$ & $0.9(\mathrm{R}-5)$ & $0.9(\mathrm{R}-5)$ & $1.4(\mathrm{R}-8)$ & $1.4(\mathrm{R}-8)$ \\
\hline
\end{tabular}


Table A-5 (continued). Home characteristics by climate zone and year of construction

\begin{tabular}{|c|c|c|c|c|c|c|}
\hline City & \multicolumn{6}{|c|}{ Worchester, MA } \\
\hline Home vintage & $<1950$ & $1950-1969$ & 1970-1989 & 1990-2009 & $\begin{array}{c}2010-2015 \\
(2010-2029) \\
\end{array}$ & $2030-2050$ \\
\hline $\begin{array}{c}\text { Floor Insulation } \\
\left(\mathbf{m}^{2} \mathbf{K} / \mathbf{W}\right)\end{array}$ & Uninsulated & Uninsulated & Uninsulated & $3.7(\mathrm{R}-21)$ & $5.3(\mathrm{R}-30)$ & $6.7(\mathrm{R}-38)$ \\
\hline Exterior Wall Material & Wood, light & Wood, light & Wood, light & Vinyl, light & Vinyl, light & Vinyl, light \\
\hline $\begin{array}{c}\text { Wall insulation } \\
\left(\mathrm{m}^{2} \mathbf{K} / \mathbf{W}\right)\end{array}$ & Uninsulated & Uninsulated & $2.3(\mathrm{R}-13)$ & $3.7(\mathrm{R}-21)$ & $5.8(\mathrm{R}-33)$ & $7.0(\mathrm{R}-40)$ \\
\hline Wall Characteristics & $\begin{array}{c}\text { Fiberglass } \\
\text { batt } \\
\text { Gr-1, } 2 \times 4, \\
16 \text { in o.c. }\end{array}$ & $\begin{array}{c}\text { Fiberglass } \\
\text { batt } \\
\text { Gr-1, } 2 \times 4, \\
16 \text { in o.c. }\end{array}$ & $\begin{array}{c}\text { Fiberglass } \\
\text { batt } \\
\text { Gr-1, } 2 \times 4 \text {, } \\
16 \text { in o.c. }\end{array}$ & $\begin{array}{c}\text { Fiberglass } \\
\text { batt } \\
\text { Gr-1, } 2 \times 4, \\
16 \text { in o.c. }\end{array}$ & $\begin{array}{c}\text { Fiberglass } \\
\text { batt } \\
\text { Gr- } 1,2 \times 4 \text {, } \\
16 \text { in o.c. }\end{array}$ & $\begin{array}{c}\text { Fiberglass } \\
\text { batt } \\
\text { Gr-1, } 2 \times 4, \\
16 \text { in o.c. }\end{array}$ \\
\hline $\begin{array}{l}\text { Attic Insulation } \\
\left(\mathrm{m}^{2} \mathrm{~K} / \mathrm{W}\right)\end{array}$ & Uninsulated & $3.9(\mathrm{R}-22)$ & $4.8(\mathrm{R}-27)$ & $8.6(\mathrm{R}-49)$ & $6.7(\mathrm{R}-38)$ & $10.6(\mathrm{R}-60)$ \\
\hline $\begin{array}{c}\text { Window U-Value } \\
\left(\mathbf{W} / \mathbf{m}^{2} \mathbf{K}\right)\end{array}$ & 3.1 & 3.5 & 2.6 & 2.0 & 2.0 & 1.5 \\
\hline Window SHGC & 0.65 & 0.66 & 0.59 & 0.59 & 0.59 & 0.59 \\
\hline $\begin{array}{c}\text { Duct Insulation } \\
\left(\mathrm{m}^{2} \mathrm{~K} / \mathrm{W}\right)\end{array}$ & $0.7(\mathrm{R}-4)$ & $0.7(\mathrm{R}-4)$ & $0.9(\mathrm{R}-5)$ & $0.9(\mathrm{R}-5)$ & $1.4(\mathrm{R}-8)$ & $1.4(\mathrm{R}-8)$ \\
\hline
\end{tabular}


Table A-6. Relative proportion of detached homes (DH) in each of the 9 Census Divisions

\begin{tabular}{|c|c|c|c|c|c|c|c|c|c|c|}
\hline $\begin{array}{c}\text { Model } \\
\text { Number }\end{array}$ & $\begin{array}{c}\text { New } \\
\text { England }\end{array}$ & $\begin{array}{l}\text { Middle } \\
\text { Atlantic }\end{array}$ & $\begin{array}{c}\text { East } \\
\text { North } \\
\text { Central } \\
\end{array}$ & $\begin{array}{c}\text { West } \\
\text { North } \\
\text { Central } \\
\end{array}$ & $\begin{array}{c}\text { South } \\
\text { Atlantic }\end{array}$ & $\begin{array}{c}\text { East } \\
\text { South } \\
\text { Central }\end{array}$ & $\begin{array}{c}\text { West } \\
\text { South } \\
\text { Central }\end{array}$ & $\begin{array}{l}\text { Mountain } \\
\text { North }\end{array}$ & $\begin{array}{l}\text { Mountain } \\
\text { South }\end{array}$ & Pacific \\
\hline DH-1 & $0 \%$ & $0 \%$ & $0 \%$ & $0 \%$ & $0 \%$ & $0 \%$ & $32 \%$ & $0 \%$ & $0 \%$ & $68 \%$ \\
\hline DH-2 & $6 \%$ & $11 \%$ & $20 \%$ & $6 \%$ & $8 \%$ & $13 \%$ & $0 \%$ & $0 \%$ & $0 \%$ & $36 \%$ \\
\hline DH-3 & $5 \%$ & $63 \%$ & $6 \%$ & $26 \%$ & $0 \%$ & $0 \%$ & $0 \%$ & $0 \%$ & $0 \%$ & $0 \%$ \\
\hline DH-4 & $0 \%$ & $2 \%$ & $0 \%$ & $2 \%$ & $26 \%$ & $18 \%$ & $14 \%$ & $4 \%$ & $2 \%$ & $33 \%$ \\
\hline DH-5 & $0 \%$ & $0 \%$ & $31 \%$ & $0 \%$ & $7 \%$ & $6 \%$ & $20 \%$ & $4 \%$ & $0 \%$ & $32 \%$ \\
\hline DH-6 & $36 \%$ & $0 \%$ & $0 \%$ & $16 \%$ & $19 \%$ & $7 \%$ & $0 \%$ & $21 \%$ & $0 \%$ & $0 \%$ \\
\hline DH-7 & $2 \%$ & $0 \%$ & $5 \%$ & $2 \%$ & $39 \%$ & $8 \%$ & $31 \%$ & $3 \%$ & $0 \%$ & $10 \%$ \\
\hline DH-8 & $0 \%$ & $8 \%$ & $13 \%$ & $4 \%$ & $14 \%$ & $10 \%$ & $16 \%$ & $0 \%$ & $7 \%$ & $27 \%$ \\
\hline DH-9 & $7 \%$ & $7 \%$ & $8 \%$ & $0 \%$ & $26 \%$ & $23 \%$ & $30 \%$ & $0 \%$ & $0 \%$ & $0 \%$ \\
\hline DH-10 & $0 \%$ & $10 \%$ & $6 \%$ & $0 \%$ & $32 \%$ & $0 \%$ & $9 \%$ & $9 \%$ & $0 \%$ & $34 \%$ \\
\hline DH-11 & $0 \%$ & $5 \%$ & $0 \%$ & $0 \%$ & $42 \%$ & $13 \%$ & $29 \%$ & $0 \%$ & $10 \%$ & $0 \%$ \\
\hline DH-12 & $7 \%$ & $56 \%$ & $12 \%$ & $0 \%$ & $25 \%$ & $0 \%$ & $0 \%$ & $0 \%$ & $0 \%$ & $0 \%$ \\
\hline DH-13 & $4 \%$ & $55 \%$ & $4 \%$ & $0 \%$ & $18 \%$ & $0 \%$ & $0 \%$ & $0 \%$ & $0 \%$ & $19 \%$ \\
\hline DH-14 & $0 \%$ & $0 \%$ & $0 \%$ & $0 \%$ & $26 \%$ & $17 \%$ & $29 \%$ & $0 \%$ & $9 \%$ & $19 \%$ \\
\hline DH-15 & $0 \%$ & $0 \%$ & $22 \%$ & $0 \%$ & $0 \%$ & $0 \%$ & $38 \%$ & $0 \%$ & $0 \%$ & $40 \%$ \\
\hline DH-16 & $0 \%$ & $0 \%$ & $8 \%$ & $5 \%$ & $27 \%$ & $8 \%$ & $39 \%$ & $0 \%$ & $0 \%$ & $13 \%$ \\
\hline DH-17 & $0 \%$ & $17 \%$ & $0 \%$ & $0 \%$ & $42 \%$ & $5 \%$ & $16 \%$ & $0 \%$ & $0 \%$ & $19 \%$ \\
\hline DH-18 & $0 \%$ & $5 \%$ & $0 \%$ & $0 \%$ & $20 \%$ & $20 \%$ & $0 \%$ & $11 \%$ & $9 \%$ & $34 \%$ \\
\hline DH-19 & $7 \%$ & $40 \%$ & $33 \%$ & $15 \%$ & $0 \%$ & $0 \%$ & $0 \%$ & $0 \%$ & $0 \%$ & $4 \%$ \\
\hline DH-20 & $32 \%$ & $32 \%$ & $7 \%$ & $17 \%$ & $0 \%$ & $0 \%$ & $0 \%$ & $0 \%$ & $0 \%$ & $12 \%$ \\
\hline DH-21 & $8 \%$ & $13 \%$ & $32 \%$ & $0 \%$ & $0 \%$ & $0 \%$ & $0 \%$ & $46 \%$ & $0 \%$ & $0 \%$ \\
\hline DH-22 & $0 \%$ & $0 \%$ & $0 \%$ & $0 \%$ & $16 \%$ & $0 \%$ & $26 \%$ & $12 \%$ & $27 \%$ & $19 \%$ \\
\hline DH-23 & $0 \%$ & $0 \%$ & $12 \%$ & $0 \%$ & $12 \%$ & $0 \%$ & $14 \%$ & $0 \%$ & $10 \%$ & $52 \%$ \\
\hline DH-24 & $0 \%$ & $0 \%$ & $20 \%$ & $0 \%$ & $0 \%$ & $0 \%$ & $11 \%$ & $0 \%$ & $0 \%$ & $69 \%$ \\
\hline DH-25 & $0 \%$ & $0 \%$ & $44 \%$ & $24 \%$ & $0 \%$ & $8 \%$ & $0 \%$ & $5 \%$ & $0 \%$ & $19 \%$ \\
\hline DH-26 & $3 \%$ & $13 \%$ & $41 \%$ & $17 \%$ & $3 \%$ & $7 \%$ & $0 \%$ & $1 \%$ & $3 \%$ & $13 \%$ \\
\hline DH-27 & $5 \%$ & $0 \%$ & $51 \%$ & $25 \%$ & $15 \%$ & $0 \%$ & $0 \%$ & $3 \%$ & $0 \%$ & $0 \%$ \\
\hline DH-28 & $0 \%$ & $0 \%$ & $8 \%$ & $9 \%$ & $26 \%$ & $15 \%$ & $22 \%$ & $6 \%$ & $3 \%$ & $10 \%$ \\
\hline DH-29 & $6 \%$ & $5 \%$ & $26 \%$ & $50 \%$ & $0 \%$ & $3 \%$ & $0 \%$ & $0 \%$ & $0 \%$ & $10 \%$ \\
\hline DH-30 & $8 \%$ & $15 \%$ & $35 \%$ & $27 \%$ & $0 \%$ & $6 \%$ & $0 \%$ & $0 \%$ & $0 \%$ & $9 \%$ \\
\hline DH-31 & $0 \%$ & $0 \%$ & $9 \%$ & $3 \%$ & $7 \%$ & $8 \%$ & $30 \%$ & $0 \%$ & $6 \%$ & $36 \%$ \\
\hline DH-32 & $15 \%$ & $14 \%$ & $19 \%$ & $15 \%$ & $13 \%$ & $16 \%$ & $0 \%$ & $5 \%$ & $0 \%$ & $3 \%$ \\
\hline DH-33 & $0 \%$ & $20 \%$ & $19 \%$ & $10 \%$ & $25 \%$ & $17 \%$ & $0 \%$ & $0 \%$ & $0 \%$ & $10 \%$ \\
\hline DH-34 & $20 \%$ & $42 \%$ & $0 \%$ & $8 \%$ & $30 \%$ & $0 \%$ & $0 \%$ & $0 \%$ & $0 \%$ & $0 \%$ \\
\hline DH-35 & $1 \%$ & $2 \%$ & $7 \%$ & $7 \%$ & $24 \%$ & $14 \%$ & $20 \%$ & $6 \%$ & $6 \%$ & $13 \%$ \\
\hline DH-36 & $0 \%$ & $11 \%$ & $52 \%$ & $23 \%$ & $13 \%$ & $0 \%$ & $0 \%$ & $0 \%$ & $0 \%$ & $0 \%$ \\
\hline DH-37 & $0 \%$ & $0 \%$ & $35 \%$ & $32 \%$ & $8 \%$ & $11 \%$ & $0 \%$ & $0 \%$ & $0 \%$ & $15 \%$ \\
\hline DH-38 & $0 \%$ & $2 \%$ & $5 \%$ & $1 \%$ & $22 \%$ & $8 \%$ & $30 \%$ & $2 \%$ & $7 \%$ & $23 \%$ \\
\hline DH-39 & $0 \%$ & $12 \%$ & $6 \%$ & $0 \%$ & $12 \%$ & $7 \%$ & $22 \%$ & $0 \%$ & $9 \%$ & $32 \%$ \\
\hline DH-40 & $0 \%$ & $0 \%$ & $20 \%$ & $26 \%$ & $21 \%$ & $27 \%$ & $0 \%$ & $0 \%$ & $0 \%$ & $6 \%$ \\
\hline DH-41 & $4 \%$ & $3 \%$ & $8 \%$ & $3 \%$ & $44 \%$ & $20 \%$ & $10 \%$ & $0 \%$ & $2 \%$ & $7 \%$ \\
\hline DH-42 & $1 \%$ & $0 \%$ & $4 \%$ & $1 \%$ & $27 \%$ & $8 \%$ & $19 \%$ & $5 \%$ & $6 \%$ & $28 \%$ \\
\hline DH-43 & $0 \%$ & $0 \%$ & $0 \%$ & $0 \%$ & $30 \%$ & $0 \%$ & $37 \%$ & $9 \%$ & $6 \%$ & $17 \%$ \\
\hline DH-44 & $2 \%$ & $6 \%$ & $6 \%$ & $2 \%$ & $35 \%$ & $23 \%$ & $8 \%$ & $3 \%$ & $5 \%$ & $11 \%$ \\
\hline DH-45 & $0 \%$ & $0 \%$ & $12 \%$ & $0 \%$ & $21 \%$ & $10 \%$ & $24 \%$ & $0 \%$ & $13 \%$ & $20 \%$ \\
\hline DH-46 & $0 \%$ & $0 \%$ & $47 \%$ & $0 \%$ & $10 \%$ & $4 \%$ & $0 \%$ & $0 \%$ & $0 \%$ & $39 \%$ \\
\hline DH-47 & $10 \%$ & $0 \%$ & $43 \%$ & $9 \%$ & $0 \%$ & $0 \%$ & $0 \%$ & $38 \%$ & $0 \%$ & $0 \%$ \\
\hline DH-48 & $7 \%$ & $15 \%$ & $32 \%$ & $29 \%$ & $10 \%$ & $3 \%$ & $0 \%$ & $0 \%$ & $0 \%$ & $4 \%$ \\
\hline DH-49 & $18 \%$ & $8 \%$ & $42 \%$ & $17 \%$ & $6 \%$ & $2 \%$ & $0 \%$ & $1 \%$ & $0 \%$ & $5 \%$ \\
\hline DH-50 & $2 \%$ & $0 \%$ & $21 \%$ & $6 \%$ & $16 \%$ & $7 \%$ & $30 \%$ & $0 \%$ & $0 \%$ & $17 \%$ \\
\hline DH-51 & $4 \%$ & $29 \%$ & $40 \%$ & $16 \%$ & $6 \%$ & $0 \%$ & $0 \%$ & $3 \%$ & $0 \%$ & $2 \%$ \\
\hline DH-52 & $0 \%$ & $6 \%$ & $5 \%$ & $4 \%$ & $23 \%$ & $4 \%$ & $30 \%$ & $0 \%$ & $4 \%$ & $24 \%$ \\
\hline DH-53 & $5 \%$ & $9 \%$ & $41 \%$ & $18 \%$ & $22 \%$ & $0 \%$ & $0 \%$ & $1 \%$ & $0 \%$ & $3 \%$ \\
\hline DH-54 & $0 \%$ & $25 \%$ & $31 \%$ & $35 \%$ & $0 \%$ & $9 \%$ & $0 \%$ & $0 \%$ & $0 \%$ & $0 \%$ \\
\hline DH-55 & $17 \%$ & $50 \%$ & $25 \%$ & $0 \%$ & $0 \%$ & $9 \%$ & $0 \%$ & $0 \%$ & $0 \%$ & $0 \%$ \\
\hline
\end{tabular}




\begin{tabular}{|c|c|c|c|c|c|c|c|c|c|c|}
\hline DH-56 & $0 \%$ & $0 \%$ & $9 \%$ & $2 \%$ & $35 \%$ & $23 \%$ & $11 \%$ & $0 \%$ & $10 \%$ & $10 \%$ \\
\hline DH-57 & $6 \%$ & $0 \%$ & $49 \%$ & $0 \%$ & $39 \%$ & $7 \%$ & $0 \%$ & $0 \%$ & $0 \%$ & $0 \%$ \\
\hline DH-58 & $5 \%$ & $18 \%$ & $30 \%$ & $17 \%$ & $15 \%$ & $5 \%$ & $0 \%$ & $8 \%$ & $0 \%$ & $2 \%$ \\
\hline DH-59 & $0 \%$ & $0 \%$ & $55 \%$ & $19 \%$ & $10 \%$ & $0 \%$ & $0 \%$ & $15 \%$ & $0 \%$ & $0 \%$ \\
\hline DH-60 & $0 \%$ & $43 \%$ & $0 \%$ & $0 \%$ & $42 \%$ & $0 \%$ & $0 \%$ & $0 \%$ & $0 \%$ & $15 \%$ \\
\hline DH-61 & $3 \%$ & $1 \%$ & $1 \%$ & $0 \%$ & $23 \%$ & $8 \%$ & $34 \%$ & $0 \%$ & $11 \%$ & $19 \%$ \\
\hline DH-62 & $0 \%$ & $3 \%$ & $3 \%$ & $2 \%$ & $22 \%$ & $0 \%$ & $13 \%$ & $9 \%$ & $3 \%$ & $45 \%$ \\
\hline DH-63 & $0 \%$ & $15 \%$ & $18 \%$ & $25 \%$ & $38 \%$ & $0 \%$ & $0 \%$ & $4 \%$ & $0 \%$ & $0 \%$ \\
\hline DH-64 & $0 \%$ & $0 \%$ & $2 \%$ & $0 \%$ & $47 \%$ & $8 \%$ & $33 \%$ & $0 \%$ & $4 \%$ & $6 \%$ \\
\hline DH-65 & $0 \%$ & $6 \%$ & $30 \%$ & $59 \%$ & $5 \%$ & $0 \%$ & $0 \%$ & $0 \%$ & $0 \%$ & $0 \%$ \\
\hline DH-66 & $0 \%$ & $23 \%$ & $23 \%$ & $31 \%$ & $8 \%$ & $0 \%$ & $0 \%$ & $9 \%$ & $0 \%$ & $7 \%$ \\
\hline DH-67 & $3 \%$ & $33 \%$ & $31 \%$ & $0 \%$ & $16 \%$ & $0 \%$ & $0 \%$ & $14 \%$ & $0 \%$ & $3 \%$ \\
\hline DH-68 & $1 \%$ & $0 \%$ & $8 \%$ & $2 \%$ & $29 \%$ & $6 \%$ & $19 \%$ & $3 \%$ & $18 \%$ & $15 \%$ \\
\hline DH-69 & $1 \%$ & $6 \%$ & $12 \%$ & $0 \%$ & $25 \%$ & $5 \%$ & $9 \%$ & $4 \%$ & $4 \%$ & $32 \%$ \\
\hline DH-70 & $10 \%$ & $0 \%$ & $24 \%$ & $18 \%$ & $22 \%$ & $26 \%$ & $0 \%$ & $0 \%$ & $0 \%$ & $0 \%$ \\
\hline DH-71 & $0 \%$ & $3 \%$ & $9 \%$ & $0 \%$ & $34 \%$ & $14 \%$ & $30 \%$ & $0 \%$ & $3 \%$ & $6 \%$ \\
\hline DH-72 & $0 \%$ & $0 \%$ & $0 \%$ & $0 \%$ & $15 \%$ & $17 \%$ & $32 \%$ & $0 \%$ & $23 \%$ & $12 \%$ \\
\hline DH-73 & $9 \%$ & $0 \%$ & $37 \%$ & $19 \%$ & $0 \%$ & $0 \%$ & $0 \%$ & $25 \%$ & $0 \%$ & $10 \%$ \\
\hline DH-74 & $0 \%$ & $30 \%$ & $49 \%$ & $15 \%$ & $6 \%$ & $0 \%$ & $0 \%$ & $0 \%$ & $0 \%$ & $0 \%$ \\
\hline DH-75 & $0 \%$ & $16 \%$ & $32 \%$ & $39 \%$ & $0 \%$ & $6 \%$ & $0 \%$ & $7 \%$ & $0 \%$ & $0 \%$ \\
\hline DH-76 & $7 \%$ & $22 \%$ & $51 \%$ & $11 \%$ & $1 \%$ & $2 \%$ & $0 \%$ & $1 \%$ & $0 \%$ & $5 \%$ \\
\hline DH-77 & $12 \%$ & $36 \%$ & $22 \%$ & $13 \%$ & $0 \%$ & $4 \%$ & $0 \%$ & $3 \%$ & $0 \%$ & $9 \%$ \\
\hline DH-78 & $0 \%$ & $0 \%$ & $0 \%$ & $16 \%$ & $11 \%$ & $29 \%$ & $29 \%$ & $0 \%$ & $0 \%$ & $14 \%$ \\
\hline DH-79 & $0 \%$ & $0 \%$ & $0 \%$ & $20 \%$ & $33 \%$ & $13 \%$ & $0 \%$ & $0 \%$ & $0 \%$ & $33 \%$ \\
\hline DH-80 & $5 \%$ & $12 \%$ & $47 \%$ & $13 \%$ & $12 \%$ & $2 \%$ & $0 \%$ & $6 \%$ & $0 \%$ & $3 \%$ \\
\hline DH-81 & $4 \%$ & $42 \%$ & $30 \%$ & $16 \%$ & $0 \%$ & $3 \%$ & $0 \%$ & $5 \%$ & $0 \%$ & $0 \%$ \\
\hline DH-82 & $0 \%$ & $52 \%$ & $48 \%$ & $0 \%$ & $0 \%$ & $0 \%$ & $0 \%$ & $0 \%$ & $0 \%$ & $0 \%$ \\
\hline DH-83 & $0 \%$ & $0 \%$ & $0 \%$ & $0 \%$ & $0 \%$ & $0 \%$ & $50 \%$ & $0 \%$ & $24 \%$ & $26 \%$ \\
\hline DH-84 & $0 \%$ & $14 \%$ & $0 \%$ & $0 \%$ & $14 \%$ & $0 \%$ & $35 \%$ & $0 \%$ & $0 \%$ & $37 \%$ \\
\hline DH-85 & $5 \%$ & $8 \%$ & $44 \%$ & $0 \%$ & $24 \%$ & $2 \%$ & $0 \%$ & $9 \%$ & $0 \%$ & $8 \%$ \\
\hline DH-86 & $7 \%$ & $38 \%$ & $22 \%$ & $6 \%$ & $10 \%$ & $0 \%$ & $0 \%$ & $17 \%$ & $0 \%$ & $0 \%$ \\
\hline DH-87 & $0 \%$ & $0 \%$ & $11 \%$ & $0 \%$ & $28 \%$ & $4 \%$ & $35 \%$ & $0 \%$ & $17 \%$ & $6 \%$ \\
\hline DH-88 & $2 \%$ & $8 \%$ & $46 \%$ & $25 \%$ & $2 \%$ & $3 \%$ & $0 \%$ & $13 \%$ & $0 \%$ & $0 \%$ \\
\hline DH-89 & $7 \%$ & $13 \%$ & $37 \%$ & $17 \%$ & $14 \%$ & $2 \%$ & $0 \%$ & $9 \%$ & $0 \%$ & $1 \%$ \\
\hline DH-90 & $0 \%$ & $11 \%$ & $54 \%$ & $28 \%$ & $0 \%$ & $0 \%$ & $0 \%$ & $6 \%$ & $0 \%$ & $0 \%$ \\
\hline DH-91 & $13 \%$ & $27 \%$ & $28 \%$ & $15 \%$ & $12 \%$ & $5 \%$ & $0 \%$ & $0 \%$ & $0 \%$ & $0 \%$ \\
\hline DH-92 & $0 \%$ & $0 \%$ & $3 \%$ & $3 \%$ & $10 \%$ & $11 \%$ & $36 \%$ & $0 \%$ & $15 \%$ & $21 \%$ \\
\hline DH-93 & $0 \%$ & $0 \%$ & $7 \%$ & $2 \%$ & $35 \%$ & $5 \%$ & $25 \%$ & $0 \%$ & $3 \%$ & $24 \%$ \\
\hline DH-94 & $36 \%$ & $15 \%$ & $9 \%$ & $15 \%$ & $7 \%$ & $5 \%$ & $0 \%$ & $10 \%$ & $0 \%$ & $3 \%$ \\
\hline DH-95 & $0 \%$ & $0 \%$ & $13 \%$ & $0 \%$ & $49 \%$ & $10 \%$ & $28 \%$ & $0 \%$ & $0 \%$ & $0 \%$ \\
\hline DH-96 & $0 \%$ & $0 \%$ & $0 \%$ & $0 \%$ & $28 \%$ & $0 \%$ & $69 \%$ & $0 \%$ & $0 \%$ & $3 \%$ \\
\hline DH-97 & $4 \%$ & $10 \%$ & $41 \%$ & $18 \%$ & $4 \%$ & $6 \%$ & $0 \%$ & $17 \%$ & $0 \%$ & $0 \%$ \\
\hline DH-98 & $4 \%$ & $14 \%$ & $28 \%$ & $18 \%$ & $25 \%$ & $0 \%$ & $0 \%$ & $9 \%$ & $0 \%$ & $2 \%$ \\
\hline DH-99 & $0 \%$ & $0 \%$ & $20 \%$ & $65 \%$ & $0 \%$ & $0 \%$ & $0 \%$ & $15 \%$ & $0 \%$ & $0 \%$ \\
\hline DH-100 & $16 \%$ & $10 \%$ & $18 \%$ & $9 \%$ & $23 \%$ & $10 \%$ & $0 \%$ & $11 \%$ & $0 \%$ & $4 \%$ \\
\hline DH-101 & $0 \%$ & $0 \%$ & $2 \%$ & $0 \%$ & $27 \%$ & $9 \%$ & $35 \%$ & $1 \%$ & $15 \%$ & $11 \%$ \\
\hline DH-102 & $0 \%$ & $1 \%$ & $4 \%$ & $0 \%$ & $26 \%$ & $7 \%$ & $23 \%$ & $2 \%$ & $8 \%$ & $28 \%$ \\
\hline DH-103 & $0 \%$ & $0 \%$ & $0 \%$ & $0 \%$ & $29 \%$ & $12 \%$ & $30 \%$ & $15 \%$ & $8 \%$ & $7 \%$ \\
\hline DH-104 & $7 \%$ & $6 \%$ & $0 \%$ & $0 \%$ & $26 \%$ & $16 \%$ & $35 \%$ & $0 \%$ & $0 \%$ & $10 \%$ \\
\hline DH-105 & $0 \%$ & $10 \%$ & $8 \%$ & $36 \%$ & $46 \%$ & $0 \%$ & $0 \%$ & $0 \%$ & $0 \%$ & $0 \%$ \\
\hline DH-106 & $0 \%$ & $0 \%$ & $0 \%$ & $0 \%$ & $23 \%$ & $9 \%$ & $43 \%$ & $0 \%$ & $25 \%$ & $0 \%$ \\
\hline DH-107 & $0 \%$ & $0 \%$ & $6 \%$ & $0 \%$ & $26 \%$ & $0 \%$ & $49 \%$ & $11 \%$ & $0 \%$ & $8 \%$ \\
\hline
\end{tabular}


Table A-7. Relative proportion of attached homes (AH) in each of the 9 Census Divisions

\begin{tabular}{|c|c|c|c|c|c|c|c|c|c|c|}
\hline $\begin{array}{l}\text { Model } \\
\text { Number }\end{array}$ & $\begin{array}{c}\text { New } \\
\text { England }\end{array}$ & $\begin{array}{l}\text { Middle } \\
\text { Atlantic }\end{array}$ & $\begin{array}{c}\text { East } \\
\text { North } \\
\text { Central }\end{array}$ & $\begin{array}{c}\text { West } \\
\text { North } \\
\text { Central }\end{array}$ & $\begin{array}{l}\text { South } \\
\text { Atlantic }\end{array}$ & $\begin{array}{c}\text { East } \\
\text { South } \\
\text { Central }\end{array}$ & $\begin{array}{c}\text { West } \\
\text { South } \\
\text { Central }\end{array}$ & $\begin{array}{l}\text { Mountain } \\
\text { North }\end{array}$ & $\begin{array}{l}\text { Mountain } \\
\text { South }\end{array}$ & Pacific \\
\hline AH-1 & $0 \%$ & $90 \%$ & $0 \%$ & $10 \%$ & $0 \%$ & $0 \%$ & $0 \%$ & $0 \%$ & $0 \%$ & $0 \%$ \\
\hline $\mathrm{AH}-2$ & $0 \%$ & $0 \%$ & $0 \%$ & $28 \%$ & $0 \%$ & $20 \%$ & $22 \%$ & $0 \%$ & $0 \%$ & $30 \%$ \\
\hline AH-3 & $0 \%$ & $100 \%$ & $0 \%$ & $0 \%$ & $0 \%$ & $0 \%$ & $0 \%$ & $0 \%$ & $0 \%$ & $0 \%$ \\
\hline AH-4 & $0 \%$ & $88 \%$ & $12 \%$ & $0 \%$ & $0 \%$ & $0 \%$ & $0 \%$ & $0 \%$ & $0 \%$ & $0 \%$ \\
\hline AH-5 & $0 \%$ & $0 \%$ & $0 \%$ & $0 \%$ & $39 \%$ & $0 \%$ & $36 \%$ & $0 \%$ & $0 \%$ & $25 \%$ \\
\hline AH-6 & $100 \%$ & $0 \%$ & $0 \%$ & $0 \%$ & $0 \%$ & $0 \%$ & $0 \%$ & $0 \%$ & $0 \%$ & $0 \%$ \\
\hline AH-7 & $0 \%$ & $0 \%$ & $0 \%$ & $0 \%$ & $39 \%$ & $0 \%$ & $0 \%$ & $0 \%$ & $43 \%$ & $18 \%$ \\
\hline AH-8 & $0 \%$ & $0 \%$ & $0 \%$ & $13 \%$ & $43 \%$ & $0 \%$ & $0 \%$ & $0 \%$ & $0 \%$ & $44 \%$ \\
\hline AH-9 & $0 \%$ & $31 \%$ & $0 \%$ & $0 \%$ & $14 \%$ & $12 \%$ & $0 \%$ & $0 \%$ & $36 \%$ & $7 \%$ \\
\hline AH-10 & $0 \%$ & $0 \%$ & $0 \%$ & $0 \%$ & $56 \%$ & $0 \%$ & $0 \%$ & $0 \%$ & $0 \%$ & $44 \%$ \\
\hline $\mathrm{AH}-11$ & $0 \%$ & $0 \%$ & $34 \%$ & $25 \%$ & $0 \%$ & $0 \%$ & $0 \%$ & $0 \%$ & $0 \%$ & $41 \%$ \\
\hline AH-12 & $0 \%$ & $0 \%$ & $35 \%$ & $0 \%$ & $31 \%$ & $0 \%$ & $0 \%$ & $0 \%$ & $0 \%$ & $34 \%$ \\
\hline AH-13 & $0 \%$ & $0 \%$ & $0 \%$ & $0 \%$ & $69 \%$ & $0 \%$ & $31 \%$ & $0 \%$ & $0 \%$ & $0 \%$ \\
\hline AH-14 & $0 \%$ & $100 \%$ & $0 \%$ & $0 \%$ & $0 \%$ & $0 \%$ & $0 \%$ & $0 \%$ & $0 \%$ & $0 \%$ \\
\hline $\mathrm{AH}-15$ & $0 \%$ & $100 \%$ & $0 \%$ & $0 \%$ & $0 \%$ & $0 \%$ & $0 \%$ & $0 \%$ & $0 \%$ & $0 \%$ \\
\hline AH-16 & $0 \%$ & $100 \%$ & $0 \%$ & $0 \%$ & $0 \%$ & $0 \%$ & $0 \%$ & $0 \%$ & $0 \%$ & $0 \%$ \\
\hline AH-17 & $0 \%$ & $0 \%$ & $100 \%$ & $0 \%$ & $0 \%$ & $0 \%$ & $0 \%$ & $0 \%$ & $0 \%$ & $0 \%$ \\
\hline AH-18 & $0 \%$ & $83 \%$ & $17 \%$ & $0 \%$ & $0 \%$ & $0 \%$ & $0 \%$ & $0 \%$ & $0 \%$ & $0 \%$ \\
\hline AH-19 & $0 \%$ & $100 \%$ & $0 \%$ & $0 \%$ & $0 \%$ & $0 \%$ & $0 \%$ & $0 \%$ & $0 \%$ & $0 \%$ \\
\hline AH-20 & $28 \%$ & $0 \%$ & $0 \%$ & $21 \%$ & $0 \%$ & $0 \%$ & $0 \%$ & $50 \%$ & $0 \%$ & $0 \%$ \\
\hline $\mathrm{AH}-21$ & $12 \%$ & $54 \%$ & $21 \%$ & $0 \%$ & $14 \%$ & $0 \%$ & $0 \%$ & $0 \%$ & $0 \%$ & $0 \%$ \\
\hline AH-22 & $9 \%$ & $48 \%$ & $0 \%$ & $0 \%$ & $42 \%$ & $0 \%$ & $0 \%$ & $0 \%$ & $0 \%$ & $0 \%$ \\
\hline $\mathrm{AH}-23$ & $0 \%$ & $0 \%$ & $0 \%$ & $0 \%$ & $76 \%$ & $0 \%$ & $0 \%$ & $24 \%$ & $0 \%$ & $0 \%$ \\
\hline $\mathrm{AH}-24$ & $0 \%$ & $0 \%$ & $0 \%$ & $0 \%$ & $0 \%$ & $0 \%$ & $0 \%$ & $0 \%$ & $25 \%$ & $75 \%$ \\
\hline AH-25 & $0 \%$ & $58 \%$ & $26 \%$ & $0 \%$ & $16 \%$ & $0 \%$ & $0 \%$ & $0 \%$ & $0 \%$ & $0 \%$ \\
\hline AH-26 & $0 \%$ & $0 \%$ & $53 \%$ & $0 \%$ & $0 \%$ & $25 \%$ & $0 \%$ & $0 \%$ & $0 \%$ & $22 \%$ \\
\hline $\mathrm{AH}-27$ & $0 \%$ & $100 \%$ & $0 \%$ & $0 \%$ & $0 \%$ & $0 \%$ & $0 \%$ & $0 \%$ & $0 \%$ & $0 \%$ \\
\hline AH-28 & $0 \%$ & $100 \%$ & $0 \%$ & $0 \%$ & $0 \%$ & $0 \%$ & $0 \%$ & $0 \%$ & $0 \%$ & $0 \%$ \\
\hline AH-29 & $8 \%$ & $0 \%$ & $20 \%$ & $0 \%$ & $33 \%$ & $5 \%$ & $5 \%$ & $5 \%$ & $0 \%$ & $23 \%$ \\
\hline AH-30 & $0 \%$ & $0 \%$ & $0 \%$ & $0 \%$ & $56 \%$ & $0 \%$ & $0 \%$ & $0 \%$ & $0 \%$ & $44 \%$ \\
\hline AH-31 & $0 \%$ & $0 \%$ & $0 \%$ & $71 \%$ & $0 \%$ & $29 \%$ & $0 \%$ & $0 \%$ & $0 \%$ & $0 \%$ \\
\hline AH-32 & $0 \%$ & $0 \%$ & $0 \%$ & $0 \%$ & $20 \%$ & $0 \%$ & $17 \%$ & $7 \%$ & $20 \%$ & $37 \%$ \\
\hline AH-33 & $8 \%$ & $0 \%$ & $19 \%$ & $5 \%$ & $0 \%$ & $0 \%$ & $10 \%$ & $0 \%$ & $6 \%$ & $52 \%$ \\
\hline AH-34 & $0 \%$ & $0 \%$ & $0 \%$ & $0 \%$ & $100 \%$ & $0 \%$ & $0 \%$ & $0 \%$ & $0 \%$ & $0 \%$ \\
\hline AH-35 & $0 \%$ & $42 \%$ & $12 \%$ & $0 \%$ & $46 \%$ & $0 \%$ & $0 \%$ & $0 \%$ & $0 \%$ & $0 \%$ \\
\hline AH-36 & $0 \%$ & $0 \%$ & $0 \%$ & $7 \%$ & $42 \%$ & $3 \%$ & $19 \%$ & $0 \%$ & $0 \%$ & $30 \%$ \\
\hline AH-37 & $5 \%$ & $24 \%$ & $0 \%$ & $4 \%$ & $22 \%$ & $5 \%$ & $3 \%$ & $12 \%$ & $0 \%$ & $25 \%$ \\
\hline AH-38 & $0 \%$ & $0 \%$ & $77 \%$ & $23 \%$ & $0 \%$ & $0 \%$ & $0 \%$ & $0 \%$ & $0 \%$ & $0 \%$ \\
\hline AH-39 & $0 \%$ & $12 \%$ & $36 \%$ & $0 \%$ & $12 \%$ & $0 \%$ & $0 \%$ & $14 \%$ & $0 \%$ & $26 \%$ \\
\hline AH-40 & $4 \%$ & $9 \%$ & $11 \%$ & $9 \%$ & $31 \%$ & $0 \%$ & $15 \%$ & $0 \%$ & $8 \%$ & $13 \%$ \\
\hline $\mathrm{AH}-41$ & $0 \%$ & $0 \%$ & $0 \%$ & $0 \%$ & $58 \%$ & $42 \%$ & $0 \%$ & $0 \%$ & $0 \%$ & $0 \%$ \\
\hline AH-42 & $0 \%$ & $100 \%$ & $0 \%$ & $0 \%$ & $0 \%$ & $0 \%$ & $0 \%$ & $0 \%$ & $0 \%$ & $0 \%$ \\
\hline AH-43 & $0 \%$ & $0 \%$ & $0 \%$ & $0 \%$ & $29 \%$ & $0 \%$ & $10 \%$ & $0 \%$ & $40 \%$ & $21 \%$ \\
\hline AH-44 & $0 \%$ & $19 \%$ & $0 \%$ & $0 \%$ & $62 \%$ & $3 \%$ & $5 \%$ & $0 \%$ & $0 \%$ & $10 \%$ \\
\hline $\mathrm{AH}-45$ & $0 \%$ & $65 \%$ & $18 \%$ & $16 \%$ & $0 \%$ & $0 \%$ & $0 \%$ & $0 \%$ & $0 \%$ & $0 \%$ \\
\hline AH-46 & $0 \%$ & $0 \%$ & $100 \%$ & $0 \%$ & $0 \%$ & $0 \%$ & $0 \%$ & $0 \%$ & $0 \%$ & $0 \%$ \\
\hline AH-47 & $0 \%$ & $69 \%$ & $0 \%$ & $0 \%$ & $31 \%$ & $0 \%$ & $0 \%$ & $0 \%$ & $0 \%$ & $0 \%$ \\
\hline $\mathrm{AH}-48$ & $0 \%$ & $100 \%$ & $0 \%$ & $0 \%$ & $0 \%$ & $0 \%$ & $0 \%$ & $0 \%$ & $0 \%$ & $0 \%$ \\
\hline AH-49 & $0 \%$ & $0 \%$ & $58 \%$ & $42 \%$ & $0 \%$ & $0 \%$ & $0 \%$ & $0 \%$ & $0 \%$ & $0 \%$ \\
\hline AH-50 & $0 \%$ & $0 \%$ & $80 \%$ & $20 \%$ & $0 \%$ & $0 \%$ & $0 \%$ & $0 \%$ & $0 \%$ & $0 \%$ \\
\hline AH-51 & $0 \%$ & $0 \%$ & $41 \%$ & $0 \%$ & $20 \%$ & $0 \%$ & $0 \%$ & $0 \%$ & $8 \%$ & $31 \%$ \\
\hline AH-52 & $0 \%$ & $0 \%$ & $15 \%$ & $0 \%$ & $16 \%$ & $0 \%$ & $12 \%$ & $0 \%$ & $16 \%$ & $41 \%$ \\
\hline AH-53 & $0 \%$ & $0 \%$ & $46 \%$ & $14 \%$ & $24 \%$ & $0 \%$ & $0 \%$ & $0 \%$ & $0 \%$ & $16 \%$ \\
\hline AH-54 & $0 \%$ & $28 \%$ & $0 \%$ & $0 \%$ & $46 \%$ & $0 \%$ & $0 \%$ & $26 \%$ & $0 \%$ & $0 \%$ \\
\hline AH-55 & $0 \%$ & $0 \%$ & $0 \%$ & $0 \%$ & $100 \%$ & $0 \%$ & $0 \%$ & $0 \%$ & $0 \%$ & $0 \%$ \\
\hline
\end{tabular}




\begin{tabular}{|c|c|c|c|c|c|c|c|c|c|c|}
\hline AH-56 & $0 \%$ & $0 \%$ & $0 \%$ & $0 \%$ & $78 \%$ & $11 \%$ & $0 \%$ & $0 \%$ & $0 \%$ & $11 \%$ \\
\hline AH-57 & $0 \%$ & $0 \%$ & $0 \%$ & $0 \%$ & $100 \%$ & $0 \%$ & $0 \%$ & $0 \%$ & $0 \%$ & $0 \%$ \\
\hline AH-58 & $0 \%$ & $0 \%$ & $34 \%$ & $66 \%$ & $0 \%$ & $0 \%$ & $0 \%$ & $0 \%$ & $0 \%$ & $0 \%$ \\
\hline AH-59 & $0 \%$ & $0 \%$ & $26 \%$ & $35 \%$ & $27 \%$ & $0 \%$ & $0 \%$ & $12 \%$ & $0 \%$ & $0 \%$ \\
\hline AH-60 & $26 \%$ & $74 \%$ & $0 \%$ & $0 \%$ & $0 \%$ & $0 \%$ & $0 \%$ & $0 \%$ & $0 \%$ & $0 \%$ \\
\hline AH-61 & $0 \%$ & $49 \%$ & $0 \%$ & $0 \%$ & $0 \%$ & $0 \%$ & $0 \%$ & $25 \%$ & $0 \%$ & $26 \%$ \\
\hline AH-62 & $0 \%$ & $0 \%$ & $51 \%$ & $0 \%$ & $17 \%$ & $0 \%$ & $19 \%$ & $0 \%$ & $0 \%$ & $13 \%$ \\
\hline AH-63 & $0 \%$ & $12 \%$ & $0 \%$ & $0 \%$ & $45 \%$ & $6 \%$ & $11 \%$ & $0 \%$ & $6 \%$ & $21 \%$ \\
\hline AH-64 & $0 \%$ & $0 \%$ & $19 \%$ & $0 \%$ & $39 \%$ & $27 \%$ & $0 \%$ & $0 \%$ & $0 \%$ & $15 \%$ \\
\hline AH-65 & $50 \%$ & $0 \%$ & $0 \%$ & $0 \%$ & $50 \%$ & $0 \%$ & $0 \%$ & $0 \%$ & $0 \%$ & $0 \%$ \\
\hline AH-66 & $0 \%$ & $63 \%$ & $0 \%$ & $0 \%$ & $25 \%$ & $12 \%$ & $0 \%$ & $0 \%$ & $0 \%$ & $0 \%$ \\
\hline AH-67 & $0 \%$ & $0 \%$ & $34 \%$ & $38 \%$ & $0 \%$ & $0 \%$ & $0 \%$ & $0 \%$ & $0 \%$ & $28 \%$ \\
\hline AH-68 & $0 \%$ & $100 \%$ & $0 \%$ & $0 \%$ & $0 \%$ & $0 \%$ & $0 \%$ & $0 \%$ & $0 \%$ & $0 \%$ \\
\hline AH-69 & $0 \%$ & $63 \%$ & $0 \%$ & $18 \%$ & $19 \%$ & $0 \%$ & $0 \%$ & $0 \%$ & $0 \%$ & $0 \%$ \\
\hline AH-70 & $0 \%$ & $100 \%$ & $0 \%$ & $0 \%$ & $0 \%$ & $0 \%$ & $0 \%$ & $0 \%$ & $0 \%$ & $0 \%$ \\
\hline AH-71 & $0 \%$ & $0 \%$ & $0 \%$ & $0 \%$ & $100 \%$ & $0 \%$ & $0 \%$ & $0 \%$ & $0 \%$ & $0 \%$ \\
\hline AH-72 & $28 \%$ & $0 \%$ & $0 \%$ & $0 \%$ & $72 \%$ & $0 \%$ & $0 \%$ & $0 \%$ & $0 \%$ & $0 \%$ \\
\hline AH-73 & $0 \%$ & $55 \%$ & $0 \%$ & $13 \%$ & $32 \%$ & $0 \%$ & $0 \%$ & $0 \%$ & $0 \%$ & $0 \%$ \\
\hline AH-74 & $0 \%$ & $0 \%$ & $46 \%$ & $40 \%$ & $0 \%$ & $0 \%$ & $0 \%$ & $14 \%$ & $0 \%$ & $0 \%$ \\
\hline AH-75 & $0 \%$ & $68 \%$ & $22 \%$ & $10 \%$ & $0 \%$ & $0 \%$ & $0 \%$ & $0 \%$ & $0 \%$ & $0 \%$ \\
\hline AH-76 & $14 \%$ & $0 \%$ & $0 \%$ & $0 \%$ & $20 \%$ & $0 \%$ & $31 \%$ & $0 \%$ & $0 \%$ & $35 \%$ \\
\hline AH-77 & $0 \%$ & $0 \%$ & $100 \%$ & $0 \%$ & $0 \%$ & $0 \%$ & $0 \%$ & $0 \%$ & $0 \%$ & $0 \%$ \\
\hline AH-78 & $0 \%$ & $0 \%$ & $0 \%$ & $0 \%$ & $0 \%$ & $0 \%$ & $0 \%$ & $100 \%$ & $0 \%$ & $0 \%$ \\
\hline AH-79 & $0 \%$ & $0 \%$ & $0 \%$ & $0 \%$ & $70 \%$ & $0 \%$ & $30 \%$ & $0 \%$ & $0 \%$ & $0 \%$ \\
\hline
\end{tabular}


Table A-8. Relative proportion of apartment units (APT) in each of the 9 Census Divisions

\begin{tabular}{|c|c|c|c|c|c|c|c|c|c|c|}
\hline $\begin{array}{c}\text { Model } \\
\text { Number }\end{array}$ & $\begin{array}{c}\text { New } \\
\text { England }\end{array}$ & $\begin{array}{l}\text { Middle } \\
\text { Atlantic }\end{array}$ & $\begin{array}{c}\text { East } \\
\text { North } \\
\text { Central }\end{array}$ & $\begin{array}{c}\text { West } \\
\text { North } \\
\text { Central }\end{array}$ & $\begin{array}{c}\text { South } \\
\text { Atlantic }\end{array}$ & $\begin{array}{c}\text { East } \\
\text { South } \\
\text { Central }\end{array}$ & $\begin{array}{c}\text { West } \\
\text { South } \\
\text { Central }\end{array}$ & $\begin{array}{l}\text { Mountain } \\
\text { North }\end{array}$ & $\begin{array}{l}\text { Mountain } \\
\text { South }\end{array}$ & Pacific \\
\hline APT-1 & $20 \%$ & $45 \%$ & $8 \%$ & $3 \%$ & $17 \%$ & $1 \%$ & $0 \%$ & $3 \%$ & $3 \%$ & $0 \%$ \\
\hline APT-2 & $32 \%$ & $25 \%$ & $21 \%$ & $8 \%$ & $2 \%$ & $0 \%$ & $3 \%$ & $0 \%$ & $0 \%$ & $9 \%$ \\
\hline APT-3 & $0 \%$ & $23 \%$ & $15 \%$ & $12 \%$ & $13 \%$ & $2 \%$ & $0 \%$ & $0 \%$ & $0 \%$ & $35 \%$ \\
\hline APT-4 & $10 \%$ & $3 \%$ & $27 \%$ & $8 \%$ & $9 \%$ & $0 \%$ & $22 \%$ & $8 \%$ & $8 \%$ & $5 \%$ \\
\hline APT-5 & $7 \%$ & $23 \%$ & $21 \%$ & $9 \%$ & $0 \%$ & $2 \%$ & $11 \%$ & $0 \%$ & $10 \%$ & $17 \%$ \\
\hline APT-6 & $3 \%$ & $4 \%$ & $16 \%$ & $3 \%$ & $19 \%$ & $5 \%$ & $12 \%$ & $8 \%$ & $0 \%$ & $31 \%$ \\
\hline APT-7 & $0 \%$ & $8 \%$ & $15 \%$ & $7 \%$ & $20 \%$ & $7 \%$ & $21 \%$ & $0 \%$ & $8 \%$ & $14 \%$ \\
\hline APT-8 & $28 \%$ & $42 \%$ & $19 \%$ & $5 \%$ & $6 \%$ & $0 \%$ & $0 \%$ & $0 \%$ & $0 \%$ & $0 \%$ \\
\hline APT-9 & $3 \%$ & $57 \%$ & $19 \%$ & $2 \%$ & $13 \%$ & $5 \%$ & $0 \%$ & $0 \%$ & $0 \%$ & $0 \%$ \\
\hline APT-10 & $14 \%$ & $43 \%$ & $7 \%$ & $2 \%$ & $19 \%$ & $9 \%$ & $0 \%$ & $0 \%$ & $0 \%$ & $6 \%$ \\
\hline APT-11 & $14 \%$ & $12 \%$ & $11 \%$ & $4 \%$ & $10 \%$ & $13 \%$ & $8 \%$ & $16 \%$ & $7 \%$ & $6 \%$ \\
\hline APT-12 & $13 \%$ & $53 \%$ & $11 \%$ & $5 \%$ & $8 \%$ & $0 \%$ & $2 \%$ & $0 \%$ & $0 \%$ & $6 \%$ \\
\hline APT-13 & $27 \%$ & $20 \%$ & $26 \%$ & $0 \%$ & $0 \%$ & $0 \%$ & $20 \%$ & $3 \%$ & $0 \%$ & $4 \%$ \\
\hline APT-14 & $4 \%$ & $33 \%$ & $12 \%$ & $6 \%$ & $18 \%$ & $2 \%$ & $0 \%$ & $2 \%$ & $0 \%$ & $22 \%$ \\
\hline APT-15 & $9 \%$ & $21 \%$ & $25 \%$ & $0 \%$ & $11 \%$ & $3 \%$ & $5 \%$ & $7 \%$ & $3 \%$ & $15 \%$ \\
\hline APT-16 & $3 \%$ & $26 \%$ & $16 \%$ & $11 \%$ & $6 \%$ & $3 \%$ & $8 \%$ & $2 \%$ & $5 \%$ & $21 \%$ \\
\hline APT-17 & $5 \%$ & $6 \%$ & $7 \%$ & $7 \%$ & $22 \%$ & $7 \%$ & $12 \%$ & $7 \%$ & $6 \%$ & $21 \%$ \\
\hline APT-18 & $0 \%$ & $16 \%$ & $25 \%$ & $9 \%$ & $12 \%$ & $7 \%$ & $6 \%$ & $5 \%$ & $4 \%$ & $16 \%$ \\
\hline APT-19 & $0 \%$ & $6 \%$ & $23 \%$ & $10 \%$ & $22 \%$ & $2 \%$ & $24 \%$ & $0 \%$ & $6 \%$ & $7 \%$ \\
\hline APT-20 & $7 \%$ & $36 \%$ & $14 \%$ & $7 \%$ & $9 \%$ & $0 \%$ & $4 \%$ & $11 \%$ & $0 \%$ & $12 \%$ \\
\hline APT-21 & $0 \%$ & $4 \%$ & $9 \%$ & $4 \%$ & $42 \%$ & $6 \%$ & $17 \%$ & $3 \%$ & $3 \%$ & $13 \%$ \\
\hline APT-22 & $7 \%$ & $6 \%$ & $8 \%$ & $8 \%$ & $28 \%$ & $0 \%$ & $28 \%$ & $0 \%$ & $2 \%$ & $13 \%$ \\
\hline APT-23 & $0 \%$ & $7 \%$ & $14 \%$ & $5 \%$ & $29 \%$ & $10 \%$ & $21 \%$ & $0 \%$ & $6 \%$ & $8 \%$ \\
\hline
\end{tabular}

Table A-9. Relative proportion of manufactured homes (MH) in each of the 9 Census Divisions

\begin{tabular}{|c|c|c|c|c|c|c|c|c|c|c|}
\hline $\begin{array}{c}\text { Model } \\
\text { Number }\end{array}$ & $\begin{array}{c}\text { New } \\
\text { England }\end{array}$ & $\begin{array}{l}\text { Middle } \\
\text { Atlantic }\end{array}$ & $\begin{array}{c}\text { East } \\
\text { North } \\
\text { Central }\end{array}$ & $\begin{array}{c}\text { West } \\
\text { North } \\
\text { Central }\end{array}$ & $\begin{array}{c}\text { South } \\
\text { Atlantic }\end{array}$ & $\begin{array}{c}\text { East } \\
\text { South } \\
\text { Central }\end{array}$ & $\begin{array}{c}\text { West } \\
\text { South } \\
\text { Central }\end{array}$ & $\begin{array}{l}\text { Mountain } \\
\text { North }\end{array}$ & $\begin{array}{l}\text { Mountain } \\
\text { South }\end{array}$ & Pacific \\
\hline MH-1 & $2 \%$ & $26 \%$ & $44 \%$ & $0 \%$ & $8 \%$ & $0 \%$ & $0 \%$ & $6 \%$ & $0 \%$ & $15 \%$ \\
\hline MH-2 & $0 \%$ & $4 \%$ & $3 \%$ & $17 \%$ & $24 \%$ & $11 \%$ & $15 \%$ & $1 \%$ & $15 \%$ & $10 \%$ \\
\hline MH-3 & $4 \%$ & $7 \%$ & $15 \%$ & $6 \%$ & $30 \%$ & $9 \%$ & $4 \%$ & $9 \%$ & $0 \%$ & $16 \%$ \\
\hline MH-4 & $0 \%$ & $6 \%$ & $8 \%$ & $0 \%$ & $27 \%$ & $18 \%$ & $16 \%$ & $6 \%$ & $12 \%$ & $7 \%$ \\
\hline MH-5 & $2 \%$ & $0 \%$ & $6 \%$ & $2 \%$ & $35 \%$ & $15 \%$ & $23 \%$ & $2 \%$ & $8 \%$ & $8 \%$ \\
\hline MH-6 & $6 \%$ & $0 \%$ & $5 \%$ & $3 \%$ & $16 \%$ & $11 \%$ & $51 \%$ & $0 \%$ & $0 \%$ & $6 \%$ \\
\hline
\end{tabular}

